AUTARQUIA ASSOCIADA À UNIVERSIDADE DE SÃO PAULO

ESTUDO DO PAPEL DA PROTEÍNA P53 EM REPARO POR EXCISÃO DE BASES EM MITOCÔNDRIAS DE CÉLULAS DE MAMÍFEROS

Felipe Augusto Godoy

Tese apresentada como parte dos
requisitos para obtenção do Grau de
$\begin{aligned} & \text { Doutor em Ciências na Área } \\ & \text { de Tecnologia Nuclear-Aplicações }\end{aligned}$

Orientador:

Prof. Dr. Valter Arthur 
INSTITUTO DE PESQUISAS ENERGÉTICAS E NUCLEARES

Autarquia associada à Universidade de São Paulo

\section{ESTUDO DO PAPEL DA PROTEÍNA P53 EM REPARO POR EXCISÃO DE BASES EM MITOCÔNDRIAS DE CÉLULAS DE MAMÍFEROS}

Felipe Augusto Godoy

Tese apresentada como parte dos requisitos para obtenção do Grau de Doutor em Ciências na Área de Tecnologia Nuclear - Aplicações

Orientador:

Prof. Dr. Valter Arthur

Versão Corrigida

Versão Original disponível no IPEN

São Paulo

2018 
Auxílio FAPESP: Processo n. 2011/13553-2

AUTORIZO A REPRODUÇÃO E DIVULGAÇÃO TOTAL OU PARCIAL DESTE TRABALHO, POR QUALQUER MEIO CONVENCIONAL OU ELETRÔNICO, PARA FINS DE ESTUDO E PESQUISA, DESDE QUE CITADA A FONTE.

GODOY, F. A. Estudo do papel da proteína p53 em reparo por excisão de bases em mitocôndrias de células de mamíferos. 2018. 114 p. Tese (Doutorado em Tecnologia Nuclear), Instituto de Pesquisas Energéticas e Nucleares - IPEN-CNEN/SP. São Paulo. Disponível em: <http://www.teses.usp.br>.

\section{FICHA CATALOGRÁFICA}

Ficha catalográfica elaborada pelo Sistema de geração automática da Biblioteca IPEN/USP, com os dados fornecidos pelo(a) autor(a)

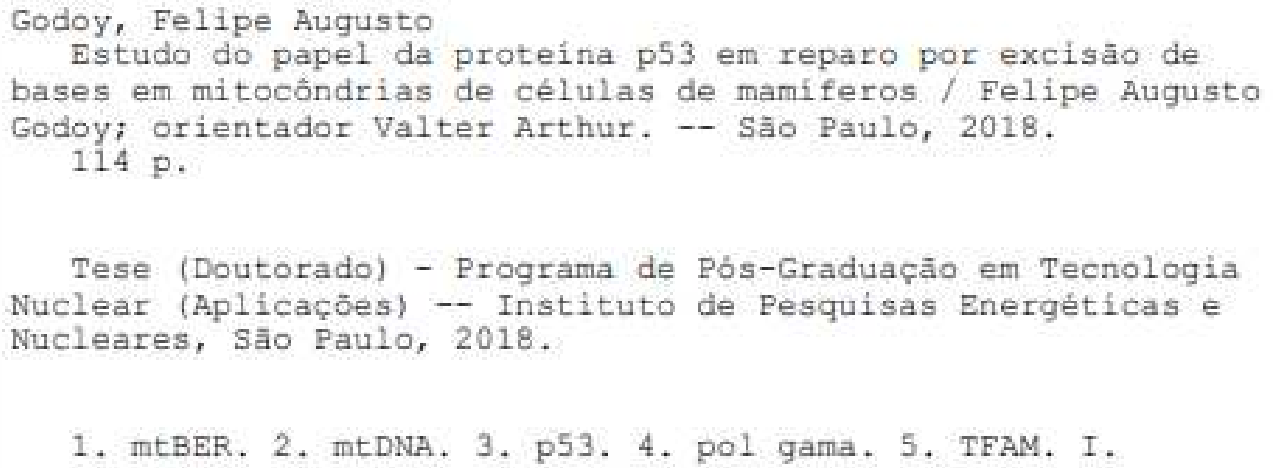




\section{FOLHA DE APROVAÇÃO}

Felipe Augusto Godoy

Estudo do papel da proteína p53 em reparo por excisão de bases em mitocôndrias de células de mamíferos

Tese apresentada ao Programa de Pós-Graduação

em Tecnologia Nuclear da Universidade de São

Paulo para obtenção do título de Doutor em Ciências.

Orientador: Prof. Dr. Valter Arthur

Data $27 / 04 / 2018$

\section{BANCA EXAMINADORA}

Prof. Dr. Valter Arthur

Instituição: CENA/USP

Julgamento: APROVADO

Prof. Dr. Leonardo Gondim de Andrade e Silva

Instituição: IPEN/USP

Julgamento: APROVADO

Profa. Dra. Márcia Nalesso Costa Harder

Instituição: FATEC

Julgamento: APROVADO

Profa. Dra. Luciana Francisco Fleuri

Instituição: UNESP

Julgamento: APROVADO 
Dedicatoria

A minha mäe, meu companheirso e meus irmäs, pelo amor e apoio incondicionais ao longo de minha vida.. 


\title{
AGRADECIMENTOS
}

\author{
"Aquilo que o coraçāo amou fica eterno" (Adélia Prado)
}

\begin{abstract}
Aos que tornaram essa minha tarefa não menos árdua, porém, mais prazerosa, tentarei retribuir com uma simples lembrança, a importância de cada um:
\end{abstract}

Ao meu orientador Valter Arthur, por sua generosidade, acolhimento, carinho e dedicação em me tornar um aluno mais cuidadoso e dedicado. Por me auxiliar em momentos de necessidade, me ensinando a não desistir nunca. Muito obrigado pela oportunidade oferecida...

À professora doutora Nadja Cristhina de Souza Pinto, que no início do meu doutorado me acolheu, acreditou em mim e possibilitou que a maioria desse projeto fosse executado, sem seu auxílio, esse projeto não teria saído do papel. Por também me auxiliar em momentos de necessidade, mesmo nas adversidades. Muito obrigado pela amizade...

Aos professores e todos os colegas do Departamento de Bioquímica do Instituto de Química e do Instituto de Pesquisas Energéticas e Nucleares que de maneira direta ou indireta contribuíram para esse trabalho. Sei que posso ser melhor do que sou, graças ao alicerce que me foi oferecido...

Aos meus queridos amigos que fiz na pós-graduação: Dri Domarques, Carol Parga, Gustavo Carvalho, Maíra Nagai e Kelme Cardoso (que chegou aos 45 do segundo tempo)...foram amigos para comemorar, alertar e ajudar...amigos para toda a vida, para o que der e vier...meu muito obrigado pelos maravilhosos momentos científicos e de descontração que passamos juntos... 
À minha querida Adriana Wendel, que com toda sua generosidade, estava sempre com um sorriso, pronta para me ajudar, não só nos experimentos, mas na minha vida...é uma pessoa que quero levar para o resto de minha caminhada...muito obrigado por tudo!!! $\ldots$

Ao pessoal do laboratório de Genética Mitocondrial e Metabolismo Mitocondrial:

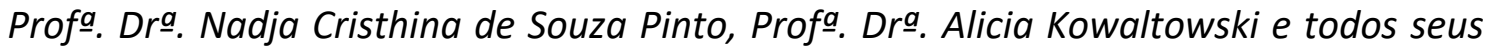
alunos e funcionários, obrigado pelas nossas discussões científicas, pelos momentos de descontração e pelo suporte experimental, cujo apoio foi imprescindível à execução deste trabalho...

Ao pessoal da Fatec Piracicaba: Fernanda Neme, Márcia Harder, Daniela Defávari, Willian Bertini, Fábio Pacano, Frederico Staufaker, Érika Gutierrez e Juliana Angelo...passamos momentos inesquecíveis juntos...verdadeiras amizades brotaram desse convívio...pessoas que levarei para o resto da vida...sem o auxílio de vocês esse caminho não seria possível...

Aos meus queridos alunos, de todas as universidades que passei, pois durante toda essa trajetória me mostraram que o caminho da docência é maravilhoso...

A Fundação de Amparo à Pesquisa do Estado de São Paulo, pelo apoio financeiro concedido para o desenvolvimento desse trabalho (Processo 2011/13553-2)

A DEUS, eterno e sábio professor, a quem agradeço cada ensinamento e a oportunidade e privilégio de poder compartilhar e disseminar tamanha experiência e conhecimento...

E também a todos de quem me esqueci!!!...são tantas as pessoas que merecem meu agradecimento, mas os neurônios estão tão escassos... 


\section{AGRADECIMENTO ESPECIAL}

"Gostamos de alguém porque; amamos alguém apesar de" (Henri de Montherland)

À minha mãe Jane e ao meu companheiro Clizio, que sempre estiveram ao meu lado, incentivando e apoiando minhas escolhas...que com seu amor, dedicação e princípios, balizaram minha vida pessoal e deram suporte para a minha vida profissional...ensinaram-me coisas essenciais da vida que, me permitiram trilhar este caminho... 
"A viagem nunca termina, o itinerário é recomposto a cada estaçāo e o destino final é sempre desconhecido" (Zygmant Bauman) 


\section{RESUMO}

GODOY, F. A. Estudo do papel da proteína p53 em reparo por excisão de bases em mitocôndrias de células de mamíferos. 2018. 114 p. Tese (Doutorado em Tecnologia Nuclear) Instituto de Pesquisas Energéticas e Nucleares-IPEN-CNEN/SP. São Paulo.

Todos os organismos vivos estão constantemente expostos a uma variedade de agentes que podem causar modificações químicas e/ou estruturais no DNA, afetando processos essenciais como replicação e transcrição. Ao longo da evolução várias estratégias de reparo do DNA foram desenvolvidas para remover essas modificações, prevenindo o efeito citotóxico ou mutagênico dessas lesões. Mutações no mtDNA são frequentemente observadas em inúmeras patologias, o que reflete em alterações metabólicas ou até mesmo atenuação da resposta apoptótica a terapias antineoplásicas. Para manter a integridade genômica mitocondrial, alguns mecanismos de reparo são recrutados à organela, principalmente a via de reparo por excisão de bases, BER. No núcleo, a proteína supressora de tumor p53 colabora para a manutenção da estabilidade do DNA, em parte pela estimulação direta da via BER. Em resposta a certos estímulos celulares, p53 transloca-se para a mitocôndria, onde pode desencadear uma resposta apoptótica. Entretanto, foi demonstrado anteriormente que p53 pode estimular a atividade catalítica da DNA polimerase mitocondrial, DNA polimerase gama (pol ү), que participa da replicação e do reparo do mtDNA. Sendo assim, nesse trabalho buscou-se compreender, molecularmente, essa interação entre p53 e pol $\gamma$ durante a modulação de BER em mitocôndrias de células humanas,

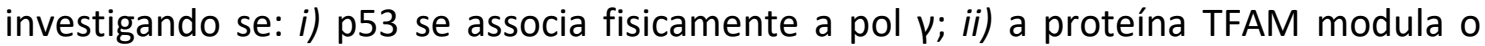
papel de p53 no reparo do DNA em mitocôndrias; e iii) a translocação de p53 para a mitocôndria é mediada por processos redox durante o reparo do mtDNA. Para isso, métodos bioquímicos e moleculares foram empregados nos estudos da interação entre essas proteínas. Em conjunto, os resultados sugerem o envolvimento da proteína p53 no reparo por excisão de bases em mitocôndrias de células humanas, e a dependência de sua interação com TFAM e pol $\gamma$ para o sustento dessa via. Isso reforça 
a importância dessas proteínas para a manutenção da estabilidade genômica mitocondrial e, provavelmente, para a função mitocondrial.

Palavras-chave: mtBER, mtDNA, p53, pol $\gamma$, TFAM. 


\begin{abstract}
GODOY, F. A. Study of the role of $\mathrm{p} 53$ protein in base excision repair in mammalian cell mitochondria. 2018. 114 p. Thesis (Doctorate in Nuclear Technology) Institute of Energy and Nuclear Research-IPEN-CNEN/SP. Sao Paulo.
\end{abstract}

All living organisms are constantly exposed to a variety of agents that can cause chemical and/or structural changes in DNA, affecting essential processes like replication and transcription. Throughout the evolution several strategies of DNA repair have been developed to remove these modifications, preventing the cytotoxic or mutagenic effect of these lesions. Mutations in mtDNA are often observed in numerous pathologies, reflecting metabolic changes or even attenuation of the apoptotic response to antineoplastic therapies. To maintain mitochondrial genomic integrity, some repair mechanisms are recruited to the organelle, mainly the base excision repair route, BER. In the nucleus, p53 tumor suppressor protein contributes to the maintenance of DNA stability, in part by direct stimulation of the BER pathway. In response to certain cellular stimuli, p53 translocate to the mitochondria, where it can trigger an apoptotic response. However, it has been shown previously that p53 can stimulate the catalytic activity of mitochondrial DNA polymerase, gamma polymerase $(\mathrm{pol} \gamma)$, which participates in the replication and repair of mtDNA. Thus, in this work we sought to understand, molecularly, this interaction between p53 and pol $\gamma$ during a modulation of BER in mitochondria human cells, investigating if: i) p53 is physically associated with pol $y$; ii) the TFAM protein modulates the role of p53 in DNA repair in mitochondria; and iii) the translocation of p53 to mitochondria is mediated by redox processes in mtDNA repair. For this, biochemical and molecular methods were used in the studies of protein interaction. Taken together, the results suggest the involvement of p53 protein in repair by base excision in mitochondria of human cells, and dependence of its interaction with TFAM and pol $\gamma$ to support this pathway. This reinforces the importance of these proteins for the maintenance of mitochondrial genomic stability and probably for mitochondrial function. 
Keywords: mtBER, mtDNA, p53, pol $\gamma$, TFAM. 


\section{LISTA DE ABREVIATURAS E SIGLAS}

\section{$\underline{1-8}$}

2-OH-Ade 2-hidroxiadenina

2'-dR 2'-desoxirribose

$3^{\prime}-\mathrm{PO}_{4}{ }^{2-} \quad 3^{\prime}$-fosfato

5-aza-dC 5-aza-2'-desoxicitidina

5'-dRP 2'-desoxirribo-5'-fosfato

$5^{\prime}-\mathrm{PO}_{4}{ }^{2-} \quad 5^{\prime}$-fosfato

6-4PP 6-4-pirimidina-pirimidona

8,5'-cdP (5'-R)- ou (5'-S)-8-ciclo-2'-desoxirribopurina

8-oxoAde 8-oxo-7,8-diidroadenina

8-oxoGua 8-oxo-7,8-diidroguanina

$\underline{A}$

AA antimicina $\mathrm{A}$

ACTB $\beta$-actina

ADP adenosina difosfato

AMP adenosina monofosfato

AMPK AMP-activated protein kinase

AP apurínico/apirimídico

APE1 AP endonuclease 1

APS persulfato de amônio

ATM ataxia-telangiectasia mutated

ATP adenosina trifosfato

B

BER reparo por excisão de bases

BGG $\quad \gamma$-globulina bovina

BHD domínio $\beta$-hairpin

BSA soro albumina bovina 
$\underline{\mathrm{C}}$

$\begin{array}{ll}\text { CAK } & \text { cyclin-activated kinase } \\ \text { CAT } & \text { carboxiatractilosídeo } \\ \text { CCCP } & \text { carbonil cianeto de 3-clorofenilahidrazona } \\ \text { CDNA } & \text { DNA complementar ao mRNA } \\ \text { CDK } & \text { cyclin-dependent kinase } \\ \text { CO } & \text { citocromo coxidase } \\ \text { COX } & \text { ciclooxigenase } \\ \text { CPD } & \text { dímero de pirimidina ciclobutano } \\ \text { CTE } & \text { cadeia de transporte de elétrons }\end{array}$

$\underline{\mathbf{D}}$

$\Delta \psi \quad$ potencial elétrico de membrana mitocondrial

DDR sinalização de dano no DNA

DMEM Dulbecco's modified eagle medium

DNA ácido desoxirribonucleico

DNA-PK protein kinase DNA-activated

DRR reparo por reversão direta

DSB quebra de fita dupla

DSRB reparo de quebra de fita dupla

DTNB ácido 5,5'-ditiobis(2-nitrobenzóico)

DTT ditiotreitol

$\underline{E}$

EDTA ácido etilenodiaminotetraacético

EGTA ácido etileno glicol-bis(2-aminoetiléter)- $\mathrm{N}, \mathrm{N}, \mathrm{N}^{\prime}, \mathrm{N}^{\prime}$-tetraacético

Endo III endonuclease III de E. coli

e.p.m. erro padrão da média

EPM extrato proteico mitocondrial

ERCC excision repair cross complementation

EROs espécies reativas de oxigênio 
$\underline{\mathbf{F}}$

FEN1 Flap endonuclease 1

FAD flavina adenina dinucleotídeo, forma oxidada

$\mathrm{FADH}_{2}$ flavina adenina dinucleotídeo, forma reduzida

FapiAde 4,6-diamino-5-formamidopirimidina

FapiGua 2,6-diamino-4-hidroxi-5-formamidopirimidina

Fe-S ferro-enxofre

FMN flavina mononucleotídeo

Fpg formamidopirimidina DNA glicosilase de $E$. coli

\section{$\underline{\mathbf{G}}$}

GG-NER reparo global do genoma por excisão de nucleotídeos

GPX glutationa peroxidase

GR glutationa redutase

GSH glutationa, forma reduzida

GSSG glutationa, forma oxidada

$\underline{H}$

HEPES ácido 4-(2-hidroxietil) piperazina-1-etanosulfônico

HPRT hypoxanthine phosphoribosyltransferase

HR recombinação homóloga

HRP peroxidase de rabanete

$\underline{L}$

LIG1 DNA ligase 1

LIG3 DNA ligase 3

LOX lipooxigenase

LP-BER BER de fragmento longo 
$\underline{\mathbf{M}}$

M1Gua pirimido $[1,2 \alpha]$ purina-10(3H)ona

MDA malondialdeído

MMR reparo de pareamento errôneo

MPG N-methylpurine-DNA glycosylase

mRNA RNA mensageiro

MSHE manitol-sacarose-HEPES-EDTA-EGTA

mtBER BER mitocondrial

mtDNA DNA mitocondrial

MT-ND1 mitochondrially encoded NADH 1 dehydrogenase

MT-ND4L mitochondrially encoded NADH 4L dehydrogenase

MTT brometo de 3-(4,5-dimetil-2-tiazolil)-2,5-difenil-2H-tetrazólio

MUTYH mutY homolog

$\underline{\mathbf{N}}$

NAD $^{+} \quad$ nicotinamida adenina dinucleotídeo, forma oxidada

NADH nicotinamida adenina dinucleotídeo, forma reduzida

NADP $^{+}$nicotinamida adenina dinucleotídeo fosfato, forma oxidada

NADPH nicotinamida adenina dinucleotídeo fosfato, forma reduzida

nDNA DNA nuclear

NEIL nei endonuclease VIII-like

NER reparo por excisão de nucleotídeos

NHEJ junção de extremidades não-homólogas

NOS óxido nítrico sintase

NOX NADPH oxidase

NRF1 nuclear respiratory factor 1

NTH1 nth endonuclease III-like 1 (E. coli)

$\underline{\mathbf{O}}$

OGG1 8-oxoguanine DNA glycosylase

Oligo oligomicina A 
$\underline{\mathbf{P}}$

p21 proteína inibidora de quinases dependentes de ciclinas

p53 proteína supressora de tumor p53

PAR poli(ADP-ribose)

PARP1 poly (ADP-ribose) polymerase

PBS solução salina tamponada com fosfato

PCNA proliferation activated nuclear antigen

PCR reação em cadeia da polimerase

PNKP1 polynucleotide kinase/phosphatase protein 1

Pol DNA polimerase

Pol G DNA polimerase gama

Pol $\gamma \quad$ DNA polimerase gama

$\underline{\mathbf{R}}$

RFC replication factor $C$

RNA ácido ribonucléico

RNA Pol RNA polimerase

ROT rotenona

RPA replication protein $A$

rRNA RNA ribossômico

RT-qPCR PCR quantitativa após reação de transcriptase reversa

$\underline{\mathbf{S}}$

SBF soro bovino fetal

SDH succinato desidrogenase

SDS dodecil sulfato de sódio

PAGE gel de poliacrilamida para eletroforese com dodecilsulfato de sódio

SOD superóxido dismutase

SP-BER BER de fragmento curto

SSB quebra de fita simples 
SSBR reparo de quebra de fita simples

$\underline{\mathbf{T}}$

TAE solução tampão Tris-acetato-EDTA

TBP TATA box binding protein

TBS Solução tampão Tris-salina

TBST solução tampão Tris-salina-Tween

TC-NER reparo acoplado à transcrição por excisão de nucleotídeos

TFAM transcription factor A mitochondrial

TFIIH transcription factor $/ / \mathrm{H}$

TLS síntese de DNA translesão

tRNA RNA transportador

Trx tioredoxina

TrxR tioredoxina redutase

TUBB $\quad \beta$-tubulina

$\underline{\mathbf{U}}$

UbQ ubiquinona

UbQ• semiubiquinona

$\mathrm{UbQH}_{2}$ ubiquinol

UNG uracil-DNA glycosylase

$\underline{\mathbf{V}}$

VDAC canal aniônico voltagem dependente

$\underline{\mathbf{X}}$

XL-PCR reação em cadeia da polimerase de fragmento longo 


\section{LISTA DE TABELAS}

Tabela 1 - Primers utilizados para qPCR para número de cópias de mtDNA.................61 


\section{LISTA DE FIGURAS}

Figura 1 - Eventos moleculares durante transformação celular em neoplasia. 32

Figura 2 - Reparo por excisão de base de fragmento curto (SP-BER) .39

Figura 3 - Reparo por excisão de base de fragmento longo (LP-BER).

Figura 4 - DNA mitocondrial (mtDNA) e a cadeia de transporte de elétrons (CTE)......43

Figura 5 - Processos moleculares mitocondriais que produzem e consomem as EROs

Figura 6 - Análise da pureza das frações celulares através de imunodetecção de PCNA e $\operatorname{cox} 4$ 65

Figura 7 - Análise da expressão de p53 em extratos celulares. .67

Figura 8 - Análise da expressão de TFAM em extratos celulares 69

Figura 9 - Análise da expressão de pol $\gamma$ em extratos celulares. 71

Figura 10 - Análise da expressão de p53 e TFAM em extratos celulares knockdown...73

Figura 11 - Análise da expressão de p53, pol $\gamma$ e TFAM em extratos celulares knockdown. . .75

Figura 12 - Western blotting de extratos de proteínas dos clones de HEK293T transfectados para knockdown de TFAM. .76

Figura 13 - Número de cópias de mtDNA em células HEK293T knockdown de p53....78 
Figura 14 - Número de cópias de mtDNA em células HEK293T knockdown de TFAM..79

Figura 15 - Análise da co-imunoprecipitação de p53, TFAM e pol y nas frações mitocondriais em extratos celulares knockdown para TFAM. .80

Figura 16 - Quantificação relativa de lesões oxidadas no mtDNA.

Figura 17 - Representação esquemática das potenciais funções nucleares e mitocondriais de p53 na manutenção do número de cópias de mtDNA... .91 


\section{SUMÁRIO}

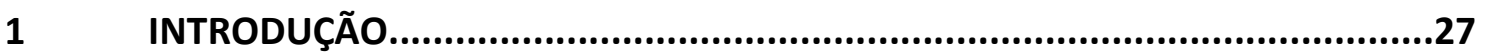

1.1 A integridade do genoma e a homeostase celular....................................................27

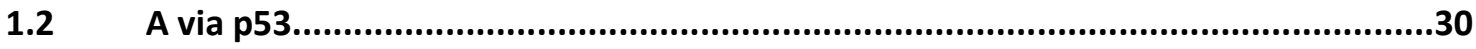

1.2.1 O papel de p53 na mitocôndria................................................................................33

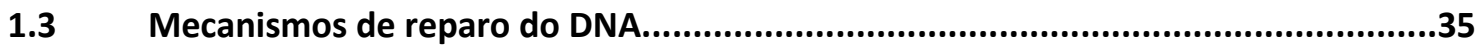

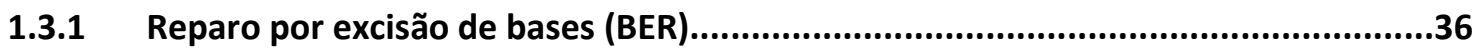

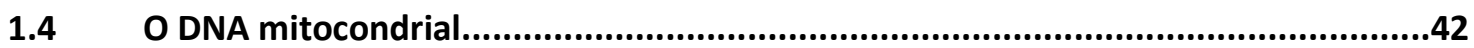

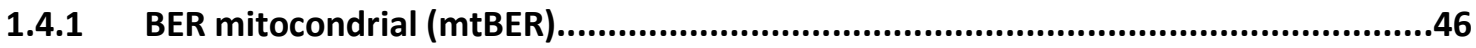

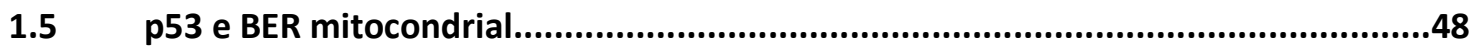

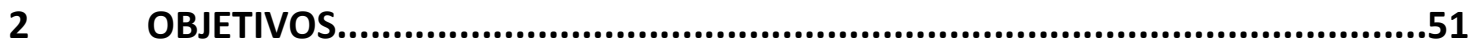

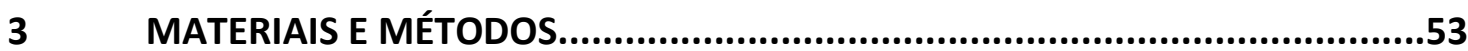

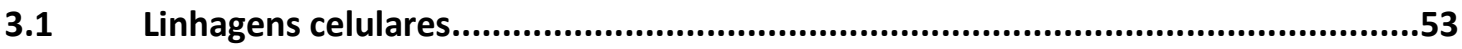

3.2 Quantificação de proteínas em extratos celulares...................................................53

3.3 Isolamento de mitocôndrias de células em cultura.................................................53

3.4 Preparação dos extratos mitocondriais...................................................................54

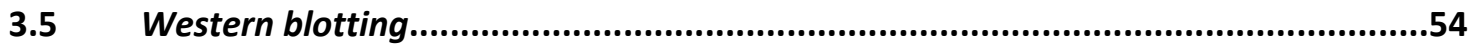

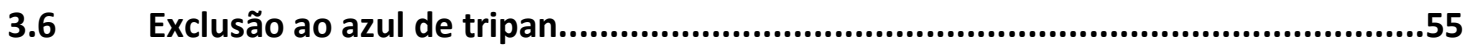

3.7 Indução de danos ao DNA usando radiação gama...................................................55

3.8 Ligação covalente dos anticorpos à proteína $A / G$ agarose.....................................55

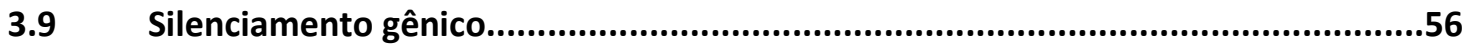

3.10 Seleção de linhagens knockdown .........................................................................58

3.11 Avaliação da porcentagem de silenciamento......................................................58

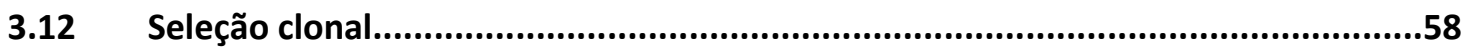

3.13 Cultivo e manutenção de células knockdown para TFAM......................................59

3.14 Transfeç̧ão de HEK293T com shRNA gene-específico..........................................59

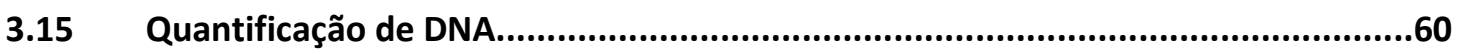

3.16 Isolamento de DNA total e análise qualitativa do número de cópias e deleções no

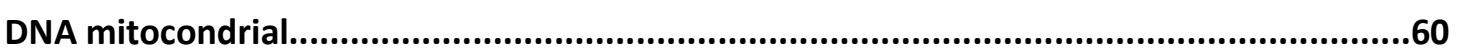

A.17 Análise de lesões em mtDNA por XL-PCR............................................................61 
4.1 Análise da pureza dos extratos mitocondriais...........................................64

4.2 Análise da expressão de p53 nas linhagens celulares..................................66

4.3 Análise da expressão de TFAM nas linhagens celulares.................................67

4.4 Análise da expressão de pol $\gamma$ nas linhagens celulares.....................................69

4.5 Análise da expressão de TFAM em células knockdown para p53......................71

4.6 Análise da expressão de pol $\gamma$ em células knockdown para p53..........................74

4.7 Quantificação de TFAM em células HEK293T transfectadas com shRNA para knockdown de TFAM............................................................................................76

4.8 Quantificação relativa do número de cópias de mtDNA em clones p53

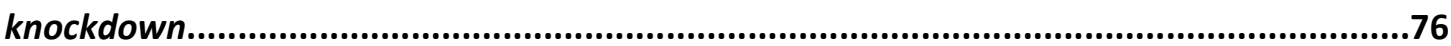

4.9 Quantificação relativa do número de cópias de mtDNA em clones TFAM

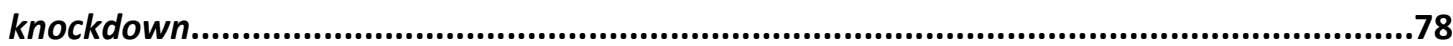

4.10 Co-imunoprecipitação nas frações mitocondriais.............................................79

4.11 Ensaio de lesão de mtDNA após estresse oxidativo..........................................80

5 DISCUSSÃO. 


\section{INTRODUÇÃO}

A proteína supressora de tumor p53 desempenha papel central no controle de vários processos como apoptose, checkpoints do ciclo celular e reparo do DNA. A via p53 possui destaque na manutenção da estabilidade genômica por meio da ativação transcricional de genes para o reparo do DNA, porém recentemente, tem sido reportada a participação direta da proteína p53 em reparo de DNA (CHEN et al., 2010).

Em resposta a certos estímulos celulares, incluindo a exposição das células a agentes que causam lesões no DNA, p53 transloca-se para a mitocôndria, onde induz apoptose independente de sua atividade transcricional, em interação direta com proteínas da família Bcl-2 (WANG, EL-DEIRY, 2003). Alguns resultados recentes indicam que p53 pode participar diretamente em reparo de DNA na mitocôndria (DE SOUZAPINTO et al., 2004; CANUGOVI et al., 2010). Entretanto, o mecanismo molecular pelo qual p53 pode modular o reparo do mtDNA ainda não é claro.

Foi demonstrado anteriormente que p53 pode estimular diretamente a atividade da DNA polimerase mitocondrial, a pol $\gamma$, que é a única DNA polimerase encontrada em mitocôndrias de células de mamíferos, e responsável tanto por replicação quanto por reparo. Nesse contexto, o objetivo deste estudo é investigar os possíveis mecanismos de interação funcional entre p53 e pol $\psi$, bem como o papel da proteína TFAM, na modulação do processo de mtBER em células humanas.

\subsection{A INTEGRIDADE DO GENOMA E A HOMEOSTASE CELULAR}

A manutenção da integridade da informação genética é desafiada constantemente por agentes reativos cuja origem pode ser exógena ou endógena ao organismo. Um exemplo bem comum para o agente externo é a luz UV, à qual estamos expostos diariamente. Esta pode ser absorvida diretamente pelo DNA e induzir reações nas bases, gerando fotoprodutos que culminam em distorções na estrutura do DNA e no bloqueio das maquinarias de replicação e transcrição, que atuam em mecanismos vitais para a célula (BOHR, 2002; HOEIJMAKERS, 2009; JACKSON e BARTEK, 2009). Além do UV, as radiações ionizantes também podem causar alterações diretas no DNA, bem como uma série de xenobióticos aos quais os organismos são expostos, que reagem 
covalentemente ou indiretamente com a molécula de DNA (CADET, RICHARD WAGNER, 2013; KONDO et al., 2010).

Quanto aos agentes endógenos, a maioria são produtos de processos do metabolismo aeróbico normal, como por exemplo as espécies reativas de oxigênio (EROs), que podem ser formadas como subprodutos do metabolismo energético mitocondrial e durante o ciclo catalítico de várias enzimas (VERCESI et al., 2007). Uma vez geradas, essas espécies podem reagir e causar modificações em proteínas, carboidratos e lipídeos, e alguns desses produtos de oxidação podem se adicionar ou reagir diretamente com o DNA (NAIR, BARTSCH, NAIR, 2007).

Dentre as EROs de relevância biológica, o radical hidroxila é a principal espécie que reage diretamente com o DNA por meio da adição de - $\mathrm{OH}$ às ligações duplas das bases nitrogenadas, abstraindo um átomo de hidrogênio do grupamento metil da timina ou promovendo a ligação C-H da 2'-desoxiribose (MUFTUOGLU, MORI, SOUZAPINTO, 2014). A importância biológica de agentes genotóxicos endógenos é demonstrada pelo fato que se estima que por dia cerca de 20.000 lesões no DNA de uma célula são geradas de forma endógena (FRIEDBERG, 2003; LINDAHL e BARNES, 2000).

As consequências biológicas de alterações químicas e/ou estruturais na molécula de DNA resultam, primariamente, dos possíveis efeitos de sua presença durante reações metabólicas normais às quais o DNA está sujeito, principalmente replicação e transcrição. A replicação de DNA contendo lesão pode resultar em mutações pontuais, tais como substituição ou deleção de bases. Um exemplo disso consiste na desaminação de citosina formando timina, a qual durante a replicação formará par canônico com a adenina levando à uma transição do par C-G para o par TA. Dessa forma, caso a célula não remova as lesões antes de iniciar a replicação, essas mutações pontuais poderão ser formadas e contribuir para os processos de carcinogênese. Esse efeito é exemplificado pela elevada predisposição ao câncer de pele associada à exposição a luz UV, que induz a formação de dímeros de timina que são mutagênicos durante a replicação (MENCK e MUNFORD, 2014).

Além de modificações de bases, espécies reativas de oxigênio podem também induzir quebras de fitas simples no DNA, que por sua vez quando presentes muito 
próximas (10 a $20 \mathrm{pb}$ ) podem resultar em quebras de duplas fitas (VAN DER SCHANS, 1978). Além disso, a presença dessas quebras pode resultar em colapso da forquilha de replicação e que por sua vez pode gerar também quebras de duplas fitas durante esse reparo (CIMPRICH e CORTEZ, 2008).

Dependendo da natureza química e estrutural das modificações no DNA, estas podem bloquear a progressão tanto de DNA- quanto RNA-polimerases. Um exemplo é o que ocorre na formação de adutos volumosos como os dímeros de pirimidina, citosina ou timina que resultam em modificações covalentes no DNA, o que impede a abertura da fita e prosseguimento da DNA polimerase durante a replicação (YANG, 2011).

Dessa forma, alterações no DNA, quando não reparadas, podem comprometer o metabolismo de DNA, acarretando em mutações, que são eventos cujos efeitos estão relacionados aos processos de câncer e envelhecimento; ou em eventos citotóxicos que ativam as vias de morte celular (MENCK e MUNFORD, 2014; POLO e JACKSON, 2011).

Dada a ubiquidade de agentes que podem causar lesões em DNA, e o papel fundamental dessa molécula como repositório de informação genética, durante a evolução os organismos vivos desenvolveram vários mecanismos de resposta a danos ao DNA (DDR, do inglês DNA damage response). Em termos gerais DDR pode ser dividida em uma série de vias distintas, mas funcionalmente entrelaçadas, que são em grande parte definidas pelo tipo de lesão presente no DNA. Na sua grande maioria essas vias abrangem um conjunto de processos firmemente coordenados, os quais incluem a detecção de danos no DNA, acumulação de fatores de reparo e finalmente o reparo efetivamente (MENCK e MUNFORD, 2014).

Para que esses processos ocorram, a maquinaria de resposta ao dano ao DNA funciona em parceria e coordenada com um conjunto de mecanismos essenciais para a manutenção da integridade do genoma, que vão desde proteínas envolvidas em remodelamento de cromatina para permitir o acesso da maquinaria de reparo, além de proteínas envolvidas em transcrição e controle do ciclo celular (BELL et al., 2011; LORD e ASHWORTH, 2012; WARMERDAM e KANAAR, 2010). 
Em sua maioria, as respostas celulares aos danos são iniciadas com a ativação de proteínas chamadas de "sensoras", que detectam a presença de modificações no DNA. Entre essas estão as proteínas ATM, ATR, DNA-PKcs além de membros da família de poli (ADP) ribose polimerase (PARP). Elas atuam na detecção dos danos e por meio de cascatas de fosforilação transmitem o sinal para moléculas "transdutoras", que por sua vez conduzem esses sinais para as moléculas "efetoras" (CICCIA e ELLEDGE, 2010; HARPER e ELLEDGE, 2007; LORD e ASHWORTH, 2012).

Um alvo proximal da atividade nessa cascata de sinalização é a histona H2AX que, após a sua fosforilação no local do dano por ATM, DNA-PK ou ATR, atua no recrutamento de proteínas que iniciam o processo de remodelagem da cromatina, o que é essencial para o acesso da maquinaria de reparo (CICCIA e ELLEDGE, 2010; CIMPRICH e CORTEZ, 2008; JACKSON e BARTEK, 2009). Além da fosforilação de histonas, ATM e ATR agem reduzindo a atividade da quinase dependente de ciclina (CDK2), por meio da ativação da transcrição de p53. Isso resulta em retardo na progressão do ciclo celular, ocasionando um aumento do tempo disponível necessário para que o reparo das lesões de DNA ocorra em etapa anterior a replicação ou a divisão celular (JACKSON e BARTEK, 2009; SU, 2006).

\subsection{A VIA p53}

O gene TP53 foi descrito pela primeira vez em 1979 (LANE, CRAWFORD, 1979; DELEO et al., 1979; LINZER, LEVINE, 1979) e está localizado no cromossomo 17p13.1. Este gene codifica uma proteína de $53 \mathrm{kDa}$, constituída de 393 aminoácidos distribuídos estruturalmente em uma cadeia com um domínio de transativação $N$ terminal, um sítio hidrofóbico de ligação ao DNA e domínios regulatórios no $C$-terminal (HAINAUT, VAHAKANGAS, 1997).

Após a identificação do gene TP53 e seu transcrito, a proteína p53, descobriuse que vários agentes eram capazes de induzir o rápido aumento dos níveis da proteína. Estes incluíam agentes que causam lesões no DNA como raios $X$, radiação UV e ionizante, drogas quimioterápicas, inibidores da síntese de DNA e uma série de sinais fisiológicos celulares (WEINBERG, 2008). 
Das muitas funções de p53, a primeira identificada foi a inibição da proliferação celular (SIONOV, HAUPT, 1999) e indução de apoptose (HEINRICHS, DEPPERT, 2003). Mais tarde, outras funções importantes foram atribuídas a p53, como inibição da angiogênese (BAKER et al., 2003) e manutenção do reparo de DNA (ALBRECHTSEN et al., 1999). Do ponto de vista de saúde humana, o grande interesse em p53 decorre do fato desse gene estar mutado em cerca de metade de todas as neoplasias humanas investigadas. Devido a esse papel crucial na prevenção do desenvolvimento da carcinogênese o gene p53 foi classificado como um supressor de tumor (WEINBERG, 2008), como mostrado na figura 1. 

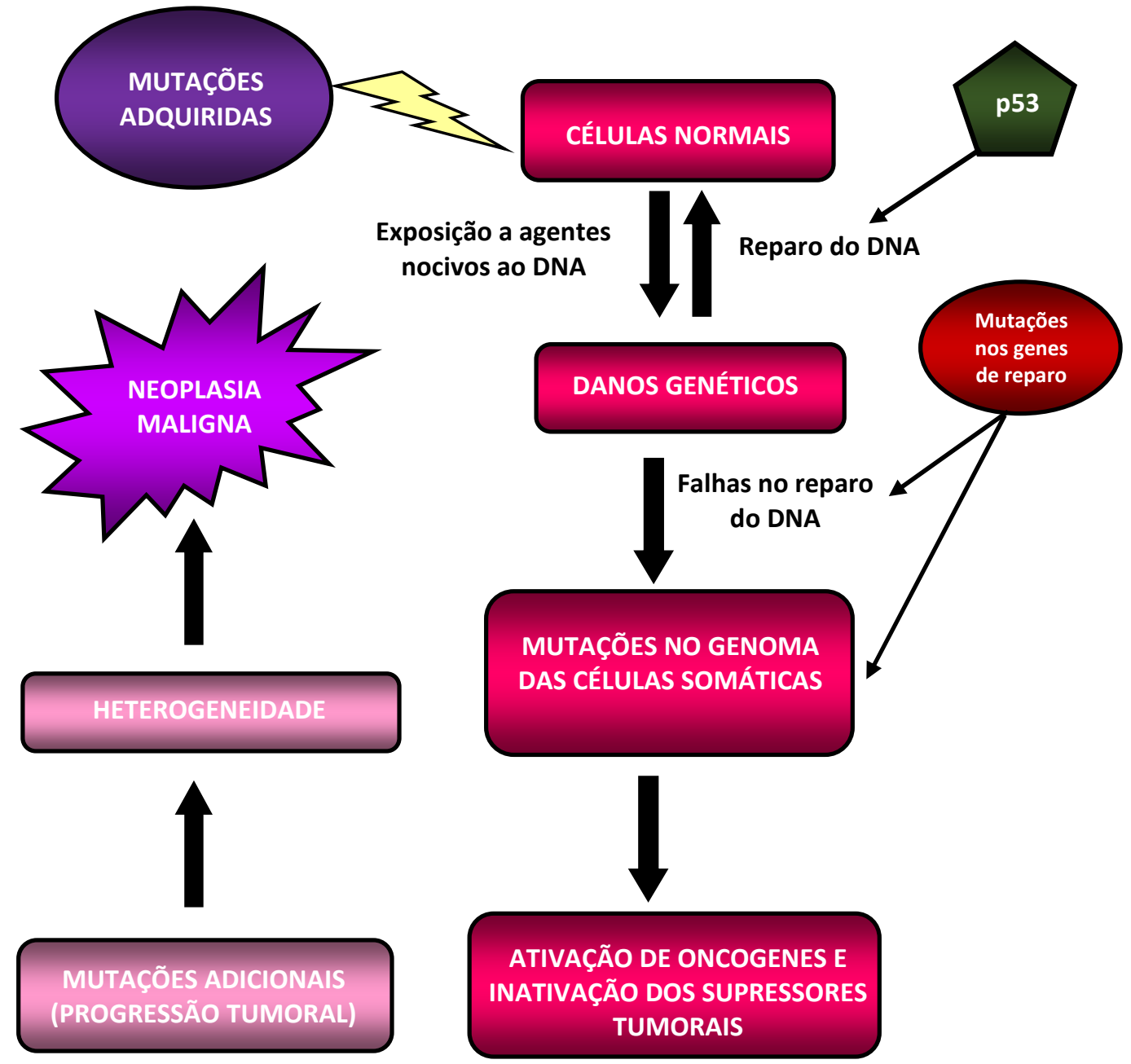

MUTAÇÕES NO GENOMA DAS CÉLULAS SOMÁTICAS

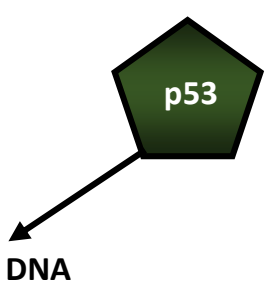

xposição a agentes

Reparo do DNA nocivos ao DNA

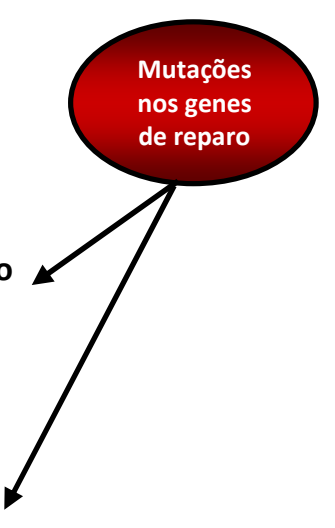

\section{DANOS GENÉTICOS}

Falhas no reparo do DNA
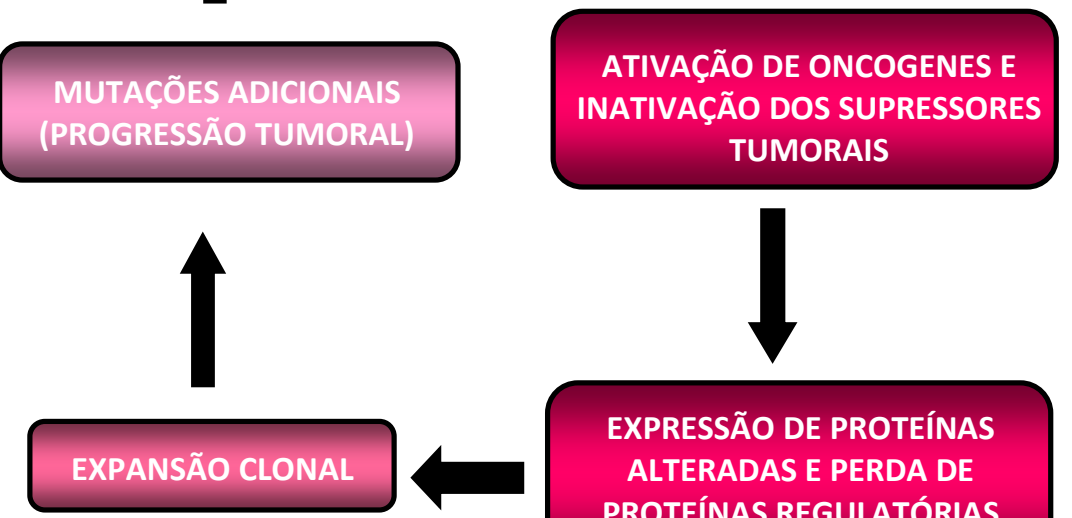

EXPRESSÃO DE PROTEÍNAS

ALTERADAS E PERDA DE

PROTEÍNAS REGULATÓRIAS

Figura 1 - Eventos moleculares durante a transformação celular.

Após estes eventos moleculares que iniciam a transformação da célula neoplásica, estas sofrem expansão clonal com diversas mutações adicionais que são responsáveis pela heterogeneidade das diferentes neoplasias. Fonte: WEINBERG, 2008.

TP53 é um fator de transcrição nuclear que, quando ativado, se liga à sítios específicos no DNA, como um tetrâmero, afetando a transcrição de genes-alvo (EIDEIRY et al., 1992), seja por ativação transcricional direta ou pela modulação da atividade de outras proteínas (GUIMARAES, HAINAUT, 2002). A ativação de p53 em 
resposta a genotoxinas resulta na indução da parada da proliferação celular, quer antes da replicação do DNA (na fase G1 do ciclo celular), ou antes da mitose (em G2). A hipótese corrente é que a parada no ciclo celular permite o reparo da lesão causada no DNA antes que as lesões sejam incorporadas como mutações (em fase S) ou resultem em aberrações cromossômicas (durante mitose). Além da parada do ciclo, p53 pode translocar-se para a mitocôndria e induzir apoptose por meio de interação direta com proteínas pró-apoptóticas da família Bcl-2, como Bax e/ou Bak (GOTTLIEB, 2000).

Como p53 possui papel central em processos que afetam funções celulares essenciais, sua atividade é estritamente regulada. Existem vários mecanismos para sua regulação, incluindo ao nível transcricional, porém acredita-se que o principal controle ocorre ao nível da proteína (PEI et al., 1999; LU et al., 1999). Estes mecanismos incluem modificações pós-traducionais, estabilidade e localização subcelular de p53 (WOODS, VOUSDEN, 2001). Entretanto, a modificação mais comum e mais estudada é certamente a fosforilação. TP53 possui pelo menos 17 possíveis sítios de fosforilação, e a fosforilação em serina 15 , no domínio N-terminal é um marcador importante da ativação da proteína em resposta a agentes genotóxicos.

No que diz respeito ao papel dessa proteína no reparo de dano no DNA, p53 facilita o recrutamento de fatores da via NER para sítios danificados no DNA após irradiação com luz UVB, sendo que esses fatores são proteínas envolvidas nos estágios iniciais de NER: XPD (componente do fator de transcrição TFIIH) XPC e CSB; por outro lado, a ausência de p53 torna mais lenta a resposta apoptótica induzida por UVB (IKEHATA et al., 2010; WANG, El-DEIRY, 2003). Foi demonstrado também, que p53 estimula a via $B E R$, independente de sua atividade transcricional, e exibe um pico de atividade entre as fazes G0 e G1 do ciclo celular após estresse genotóxico (OFFER et al., 2001a; OFFER et al., 1999; OFFER et al., 2001b). A proteína p53 interage com enzimas do eixo central de BER, AP endonuclease e DNA Polimerase $\beta$, estabilizando a interação desta última com sítios abásicos no DNA, além de estar aparentemente envolvida no controle da expressão da Pol $\beta$ (SEO et al., 2002; ZHOU et al., 2001). 


\subsubsection{O PAPEL DE p53 NA MITOCÔNDRIA}

Mudanças na função mitocondrial, com consequente alteração na produção de EROs, podem afetar a atividade de p53 e sua localização subcelular e, de fato, p53 transloca-se para a mitocôndria em resposta a estímulos que induzem apoptose (HOLLEY et al., 2010; MARCHENKO et al., 2000). Por sua vez, a proteína p53 pode afetar a produção de EROs mitocondrial regulando a expressão e interagindo diretamente com Mn-SOD, após translocar-se para a mitocôndria sob condições de estresse (ZHAO et al., 2005). A proteína p53 regula ainda a transição entre a respiração aeróbica e a glicólise controlando a expressão de SCO2, PGM e TIGAR (FENG e LEVINE, 2010).

Sob condições de estresse oxidativo, p53 provoca abertura do poro de transição de permeabilidade de membrana mitocondrial por meio da interação com a proteína ciclofilina D provocando morte celular por necrose (VASEVA et al., 2012). A localização mitocondrial de p53 - espaço intermembrana e matriz - na ausência de estresse estimula o consumo de oxigênio e diminui a produção de superóxido (BERGEAUD et al., 2013), provavelmente por estimular a enzima Mn-SOD (ZHAO et al., 2005). A proteína p53 interage com a proteína sensível à oligomicina, uma subunidade do complexo FoF1 da ATP sintase, e está aparentemente envolvida com a montagem desse complexo (BERGEAUD et al., 2013). Dessa forma, a proteína p53 desempenha, dentre tantos papéis, a comunicação entre o núcleo e a mitocôndria, contribuindo para o controle do estado redox e metabólico celular.

No que diz respeito à manutenção do genoma mitocondrial, estudos in vitro mostraram que p53 promove a estabilidade do mtDNA por meio de uma interação funcional com a DNA polimerase $\gamma($ pol $\gamma)$, além de estimular a remoção de uracila e 8oxoguanina pelas glicosilases da via BER (ACHANTA et al., 2005; CHEN et al., 2006; DE SOUZA-PINTO et al., 2004). Dentro da mitocôndria, p53 também aumenta a precisão da síntese de mtDNA por meio de sua atividade 3'-5' exonucleásica, dessa forma, atua como revisora da atividade de pol ү (BAKHANASHVILI et al., 2008). A ligação de mtSSB à p53 aumenta sua atividade $3^{\prime}-5^{\prime}$ exonucleásica, particularmente na hidrólise de 8oxoguanina (WONG et al., 2009) reforçando ainda mais o papel de p53 mitocondrial para a síntese e reparo do mtDNA. DE e colaboradores (2012) revelaram que p53 e a 
DNA helicase dependente de ATP, colocalizam com os nucleoides mitocondriais na ausência de danos ao DNA, sugerindo que essa helicase pode contribuir para o recrutamento de p53 durante a replicação do genoma mitocondrial.

Além disso, CANUGOVI e colaboradores (2010) demonstraram que a proteína TFAM, componente essencial do nucleoide mitocondrial, pode impedir o acesso de proteínas da via BER ao mtDNA, inibindo a atividade dessa via. In vitro, p53 promove a remoção de TFAM do DNA, facilitando o acesso das proteínas de reparo. Desta forma, p53 pode também contribuir para a manutenção da integridade do mtDNA por meio de sua interação funcional com TFAM.

Essas observações deixam claro que diversos arranjos de sensores são responsáveis pelo monitoramento da integridade e do funcionamento de vários sistemas celulares, incluindo o reparo do DNA nuclear e do mtDNA. E neste contexto, mais estudos detalhando como p53 modula o acúmulo de mutações após lesões necessitam ser realizados.

\subsection{MECANISMOS DE REPARO DO DNA}

O DNA é uma molécula complexa que armazena o conteúdo informacional transmitido de geração para geração. Para que essa função seja desempenhada com sucesso sua integridade deve ser mantida, apesar de sua alta instabilidade química (FRIEDBERG, 2003).

A exposição do DNA a uma variedade de agentes químicos e físicos, incluindo produtos secundários do metabolismo normal, pode produzir uma variedade de lesões em sua estrutura, afetando mecanismos celulares essenciais como sua replicação e transcrição (KAINA et al., 2007).

Apesar das mutações serem essenciais para dirigir processos evolutivos, o acúmulo de mutações pode ser bastante deletério aos sistemas biológicos. Nesse sentido, mecanismos de reparo de DNA que removem lesões impedindo sua fixação como mutações foram selecionados durante a evolução, o que assegura a transmissão fiel das informações genéticas de geração para geração (FRIEDBERG et al., 2006).

Em decorrência da grande variedade estrutural e química das modificações do DNA, várias estratégias de reparo foram selecionadas nos organismos durante a 
evolução (DE LAAT et al., 1999). Basicamente existem duas formas fundamentais de reparo de lesões em ácidos nucléicos por meio de: 1) reversão direta do dano e 2) excisão completa da lesão.

A reversão direta da lesão no DNA é o mecanismo mais simples pelo qual o DNA pode ser reparado. O mecanismo bioquímico é baseado em apenas uma reação, a qual uma única enzima específica reconhece e reverte a lesão. Esse processo, embora eficiente, é bastante limitado devido à alta especificidade entre enzima e substrato (SANCAR, 2000). Desta forma, outras estratégias mais generalizadas nas quais as lesões são retiradas e substituídas por novos nucleotídeos foram desenvolvidas (FRIEDBERG et al., 2006).

Existem vários mecanismos que atuam de maneiras distintas nessa remoção por meio do processo de reparo por excisão. Dentre eles estão o reparo de emparelhamento errôneo (MMR), reparo de quebras de fita dupla, por recombinação homóloga (HR) ou pareamento não-homólogo (NHEJ), reparo por excisão de nucleotídeos (NER) e reparo por excisão de bases (BER) (EISEN, HANAWALT, 1999). Como nossa proposta aborda o mecanismo de BER, será dado enfoque na descrição desse processo.

\subsubsection{REPARO POR EXCISÃO DE BASES (BER)}

O BER ("Base Excision Repair") é responsável pela remoção de uma grande variedade de lesões como bases desaminadas, alquiladas, oxidadas ou sítios abásicos (sítios AP) (SLUPPHAUG et al., 2003).

A via de reparo por excisão de base constitui a principal via de vigilância do genoma, uma vez que as lesões reparadas por essa via são as que mais comumente acometem o DNA. A prova desse conceito é demonstrada experimentalmente em camundongos knockout de genes que codificam para algumas proteínas da via BER (MAYNARD et al., 2010). Com exceção às DNA glicosilases, que participam da primeira etapa da via, a ausência de qualquer uma das proteínas da via BER resulta em letalidade embrionária (XANTHOUDAKIS et al., 1996; TEBBS et al., 1999; SUGO et al., 2000; PUEBLA-OSORIO et al., 2006). 
A via BER é ubíqua e altamente conservada desde bactérias até humanos, onde atua tanto no genoma nuclear quanto no genoma mitocondrial (RAO, 2007; ZHARKOV, 2008). Até mesmo o bacteriófago T4 possui um gene que codifica para uma das enzimas que participam da via BER. É uma via molecularmente muito simples, consistindo de cinco reações sequenciais, e pode ser reconstituída in vitro utilizando-se apenas quatro enzimas (DIANOV e LINDAHL, 1994).

O mecanismo molecular do BER inicia-se pelo reconhecimento e excisão da base modificada pelas DNA glicolases, com ou sem a atividade 3'-AP liase (LINDAHL, 2000). O sítio AP é então reconhecido por outro grupo de enzimas, as APendonucleases, que fazem a incisão na extremidade $3^{\prime}$ ou $5^{\prime}$ do sítio AP, gerando uma quebra de fita simples. Após a remoção da desoxiribose-fosfato do terminal 5' pela DNA polimerase de reparo (geralmente DNA polimerase $\beta$ no núcleo e $\gamma$ na mitocôndria) e inserção de um novo nucleotídeo pela mesma enzima, a fita é finalmente ligada pela DNA ligase (SLUPPHAUG et al., 2003).

O reparo pode ser completado por duas vias distintas: a via curta ("Short-Patch Repair"), em que apenas um novo nucleotídeo é incorporado, ou a via longa ("LongPatch Repair"), em que 2 a 8 nucleotídeos podem ser incorporados. A escolha de uma das vias é geralmente determinada pela natureza da DNA glicolase e do sítio AP resultante, mas também pode depender do momento do ciclo celular e da localização sub-nuclear do processo (SLUPPHAUG et al., 2003).

\section{A) BER de Fragmento Curto (SP-BER)}

Detalhadamente, a via se inicia com o reconhecimento da modificação química na base nitrogenada do DNA por uma classe de enzimas denominadas DNA glicosilases. Uma característica catalítica comum das enzimas pertencentes a esta classe é o mecanismo de flipping-out, que consiste no reposicionamento da base nitrogenada do interior da dupla hélice para fora, no bolsão catalítico da enzima (FROMME, BANERJEE e VERDINE, 2004).

No caso da modificação na nucleobase fazer contatos com aminoácidos críticos no sítio catalítico, segue-se então a clivagem ([1] da figura 2 ) da ligação N- $\beta$-glicosídica entre a base e o açúcar, resultando em um sítio apurínico/apirimídico (AP ou sítio 
abásico). Essa estrutura é, subsequentemente, alvo de clivagem hidrolítica pela ação da enzima AP endonuclease (APE1) a montante do sítio AP (i.e. na extremidade $5^{\prime}$ ) ([2] da figura 2). Isso gera um terminal 3'-OH livre e um 2'desoxirribo-5'-fosfato (5'-dRP) no outro terminal. Em seguida, a DNA polimerase $\beta$ (Pol $\beta$ ), no núcleo (WIEBAUER e JIRICNY, 1990; SINGHAL et al., 1995), ou a DNA polimerase $\gamma$, na mitocôndria (LONGLEY et al., 1998), remove a 5'-dRP e adiciona um nucleotídeo complementar ao da fita oposta ao terminal 3'-OH compatível com a síntese de DNA.

Por fim, a descontinuidade da fita danificada é resolvida pela ação da DNA ligase 3 (LIG3) em complexo da proteína XRCC1 (X-ray Chinese hamster complementation group 1) ([3] da figura 2) (WEISSMAN et al., 2007). 

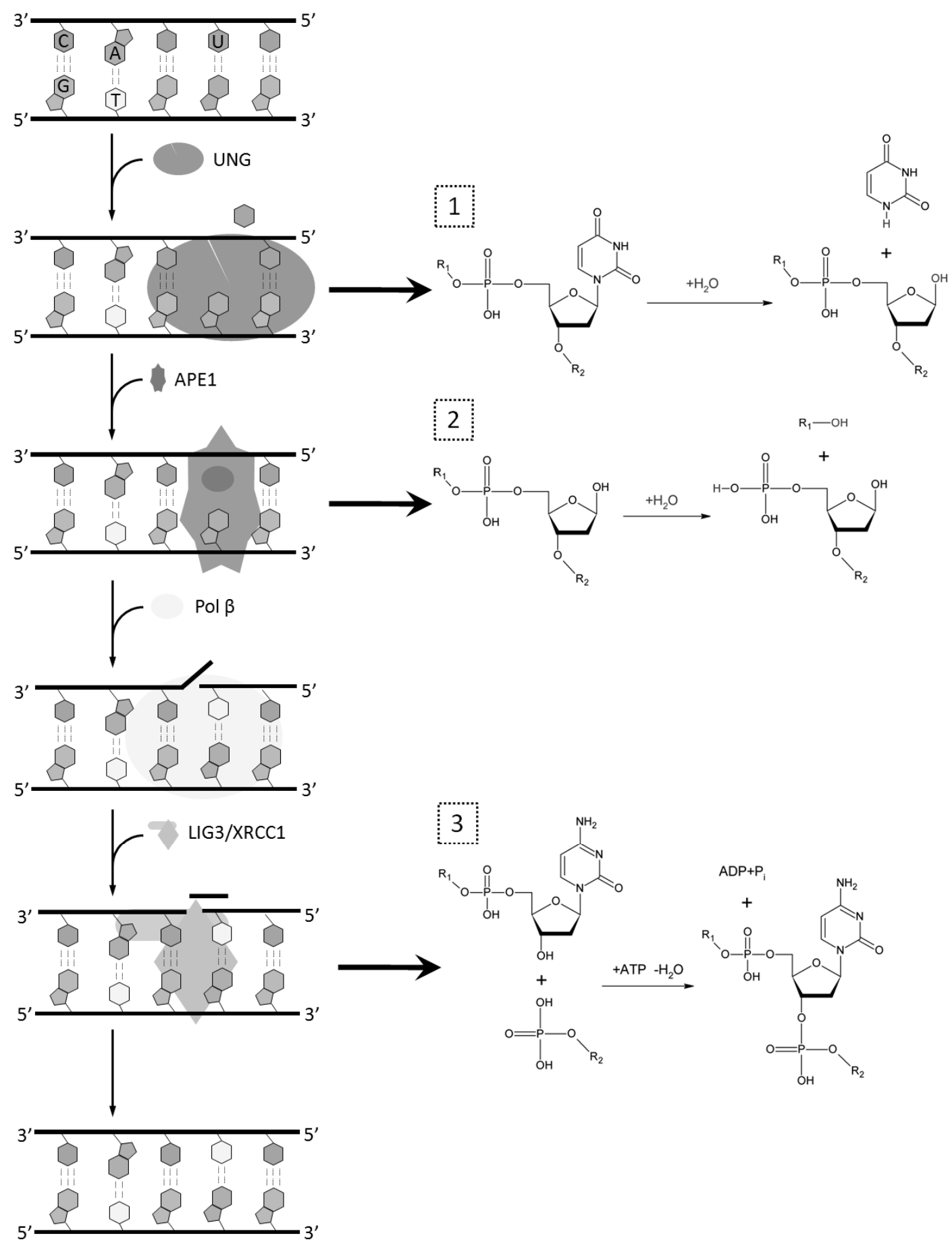

Figura 2 - Reparo por excisão de base de fragmento curto (SP-BER).

Uma Ura, produto de deaminação da Cyt, pareada com Gua é alvo da DNA glicosilase UNG. [1] Clivagem hidrolítica da ligação $N$ - $\beta$-glicosídica entre a base nitrogenada e a $2^{\prime}$-desoxirribose. [2] APE1 reconhece e executa a clivagem hidrolítica do sítio AP formado após a retirada da nucleobase. Pol $\beta$ remove dRP e insere um novo nucleotídeo a partir do terminal $3^{\prime}$-OH livre a montante da lesão. O complexo XRCC1/LIG3 sela as pontas $3^{\prime}-\mathrm{OH}$ e $5^{\prime}-\mathrm{PO}_{4}{ }^{2-}$ consumindo um ATP. Fonte: ROMAGNA, MORI, SOUZAPINTO, 2014. 


\section{B) BER de Fragmento Longo (LP-BER)}

A via BER, conforme foi descrita anteriormente, é denominada de subvia de fragmento curto (SP-BER, do inglês short patch), em referência ao fato de que apenas um novo nucleotídeo é incorporado durante o processo de reparo (DIANOV et al., 1992). Em contrapartida, existe outra subvia de BER, a de fragmento longo (LP-BER, do inglês long patch) (KLUNGLAND e LINDAHL, 1997).

Há três diferenças fundamentais na subvia LP-BER (figura 3). A primeira reside no tamanho do fragmento de DNA sintetizado durante o reparo, onde são incorporados de 2-11 nucleotídeos, pela Pol $\beta$, podendo essa DNA polimerase ser substituída pelas DNA polimerases replicativas, Pol $\delta$ e $\varepsilon$, com o auxílio das proteínas RPA (replication protein A) e PCNA (proliferation activated nuclear antigen) (DEMOTT et al., 1998). A segunda diferença se refere ao processamento da fita de DNA deslocada com a síntese do trecho mais longo que acaba se apresentando na forma de uma alça de DNA fita simples (ssDNA). Essa estrutura é incompatível com a atividade de dRP liase das DNA polimerases, sendo necessária à resolução a ação da endonuclease estrutura-específica FEN1 (Flap endonuclease 1). Por fim, a DNA ligase 1 (LIG1) é recrutada nessa subvia e catalisa a ligação das pontas estimulada especialmente por PCNA (LEVIN et al., 2000).

Existem duas classes de DNA glicosilases: i) as monofuncionais, que executam apenas a função de DNA glicosilases; ii) as bifuncionais, que apresentam uma atividade de AP liase associada. As duas classes de DNA glicosilases efetuam a catálise por meio do ataque nucleofílico no carbono-1' do açúcar (FROMME, BANERJEE e VERDINE, 2004).

Enquanto nas DNA glicosilases monofuncionais uma molécula de água ativada por um aspartato é utilizada para a catálise, nas bifuncionais o mesmo princípio catalítico via aspartato ativa um resíduo de lisina, que forma uma base de Schiff intermediária (DODSON et al., 2002). Além disso, nas DNA glicosilases bifuncionais, a atividade de AP liase resulta em uma quebra de fita via $\beta$-eliminação gerando um aldeído $3^{\prime}$ - $\alpha, \beta$-insaturado (NTH1 e OGG1) ou via $\beta, \delta$-eliminação produzindo um terminal 3'-fosfato (família nei endonuclease VIII-like). Essas duas estruturas são refratárias à atividade de $\mathrm{dRP}$ liase das DNA polimerase, sendo necessário o 
processamento subsequente para a etapa de síntese. $O$ terminal de aldeído $3^{\prime}-\alpha, \beta-$ insaturado é removido pela APE1. Por sua vez, o terminal $3^{\prime}$-fosfato $\left(3^{\prime}-\mathrm{PO}_{4}{ }^{2-}\right)$ é processado pela PNKP1 (polynucleotide kinase/phosphatase protein 1).
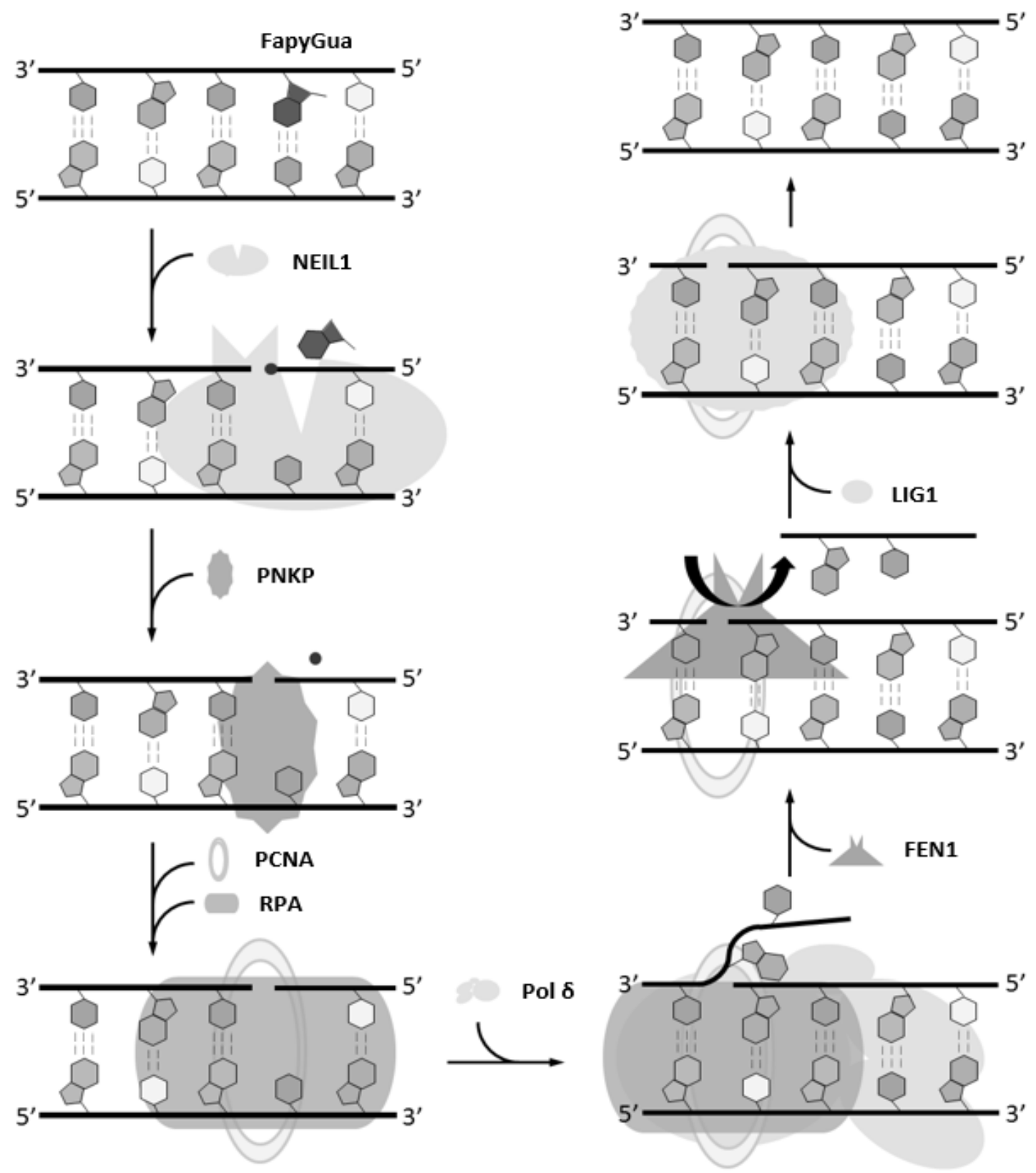

Figura 3 - Reparo por excisão de base de fragmento longo (LP-BER).

Uma 2,6-diamino-4-hidroxi-5-formamidopirimidina (FapiGua), produto de oxidação da gunaina, é alvo da DNA glicosilase NEIL1. Essa DNA glicosilase bifuncional, remove a base modificada e cliva a fita de DNA por meio da sua atividade de AP liase. $O$ terminal gerado $3^{\prime}-\mathrm{PO}_{4}{ }^{2-}$ é refratário à atividade de $\mathrm{Pol} \beta$ e PNKP é recrutado para remoção dessa estrutura. PCNA e RPA recrutam Pol $\delta$, uma DNA polimerase mais processiva. A síntese de DNA por Pol $\delta$ desloca a fita a jusante formando uma estrutura em forma de alça que é removida por FEN1. Por fim, LIG1 sela as pontas $3^{\prime}-\mathrm{OH}$ e $5^{\prime}-\mathrm{PO}_{4}{ }^{2-}$ consumindo um ATP. Fonte: ROMAGNA, MORI, SOUZA-PINTO, 2014. 


\subsection{O DNA MITOCONDRIAL}

Até quarenta anos atrás, pensava-se nas mitocôndrias como compartimento exclusivo para vias relacionadas ao metabolismo energético. Hoje, porém, sabe-se que as mitocôndrias desempenham papéis centrais em vários processos: sinalização e lesões celulares, apoptose, heranças genéticas ligadas ao mtDNA, câncer e doenças neurodegenerativas, devido à localização mitocondrial de várias proteínas e moduladores de sinalização intracelular (BOTA, DAVIES, 2001). Além disso, as mitocôndrias compreendem uma das principais vias de apoptose nas células de vertebrados (KOWALTOWSKI, VERCESI, 2001), o que fez dessas organelas o objeto de interesse em estudos de fisiopatologia.

No reino animal, a mitocôndria é a única organela que contém seu próprio DNA, com genes que codificam proteínas integrantes da cadeia respiratória, rRNAs e tRNAs (ANDERSON et al., 1981). Mutações nesse DNA podem induzir uma série de patologias que se expressam durante diferentes fases da vida (BOTA, DAVIES, 2001).

O genoma mitocondrial (mtDNA) possui uma altíssima densidade de informação. Em humanos, aproximadamente 96 \% dos 16.569 pares de bases do mtDNA compreendem os 37 genes que codificam para 13 polipeptídeos, 22 RNAs transportadores (tRNA) e 2 RNAs ribossômicos (rRNA) (MUFTUOGLU et al., 2014). Dos complexos da CTE, o mtDNA codifica sete subunidades do complexo l; uma do complexo III; três do complexo IV; e duas da ATP sintase. Além disso, em cada uma das duas fitas do mtDNA ( $\mathrm{H}$ e L, do inglês heavy e light, em referência ao conteúdo diferenciado de purinas nas duas fitas, que resulta em massa molar distinta) os genes são transcritos em um único transcrito policistrônico, a partir do promotor de cada fita (PH o promotor da fita H e PL o promotor da fita L) (BONAWITZ et al., 2006) (figura 4).

Consequentemente, uma lesão no mtDNA tem uma maior chance de acontecer em uma região codificadora, aumentando a probabilidade de consequência fenotípica da mutação, caso o mtDNA esteja sendo replicado, ou de parada da RNA polimerase mitocondrial, caso o mtDNA esteja sendo transcrito. De fato, calcula-se que mutações no mtDNA ocorram 10 vezes mais frequentemente do que no DNA nuclear (BROWN et al., 1979), apesar da razão para essa discrepância ainda não estar clara. 

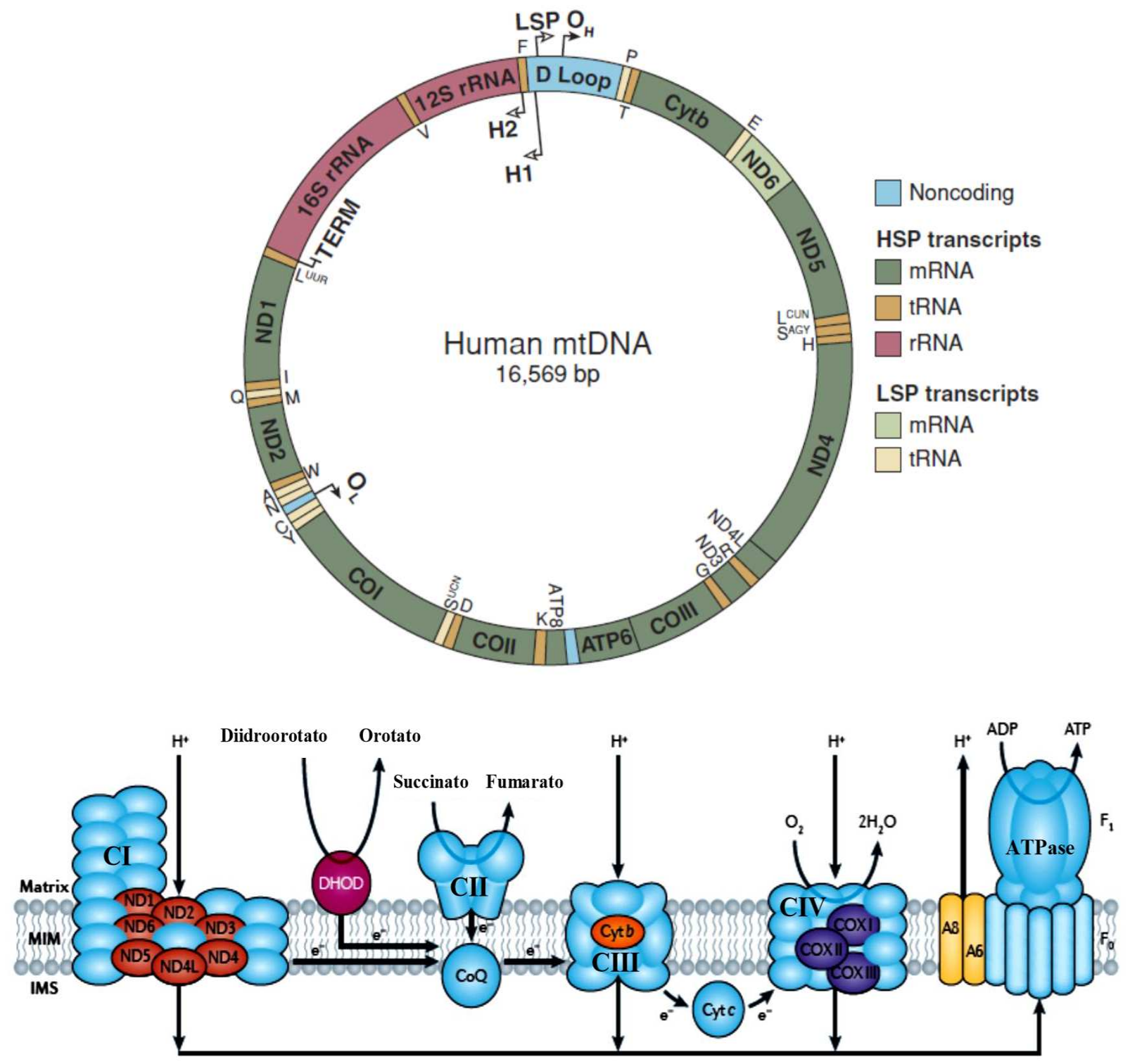

Figura 4 - DNA mitocondrial (mtDNA) e a cadeia de transporte de elétrons (CTE).

Os 37 genes codificados no mtDNA incluem sete subunidades do $\mathrm{Cl}$ (ND1, 2, 3, 4, 4L, 5 e 6), uma subunidade do CIII (citocromo b-Cyt b), três do CIV (CO1, 2 e 3) e duas da ATPase (A6 e 8), 22 tRNAs (código de uma letra) e 2 rRNAs (16S e 12S). Fonte: SCHON et al., 2012.

As mutações em mtDNA estão no centro do conceito moderno da teoria mitocondrial do envelhecimento. Essa teoria, propõe que as EROs geradas normalmente na mitocôndria são as responsáveis por causar mutações no mtDNA (HARMAN, 1972 e 1992; LINNANE et al., 1989). Ainda que o acúmulo progressivo de mutações no genoma mitocondrial durante a vida do organismo leva a disfunção mitocondrial, e esse declínio na função mitocondrial resultaria em um estresse redox, aumentando ainda mais os danos e as mutações causadas por oxidantes no mtDNA, 
gerando um ciclo vicioso (TAYLOR e TURNBULL, 2005). Contudo, pouco se sabe a respeito da regulação in vivo da geração de oxidantes nos complexos mitocondriais. Porém, há uma clara correlação positiva entre a intensidade da força próton-motriz e a produção de $\mathrm{O}_{2}{ }^{\bullet-}$, enquanto uma diminuição nesse potencial através da membrana diminui a geração de $\mathrm{O}_{2}{ }^{\bullet-}$ (KORSHUNOV et al., 1997). Especula-se que um elevado potencial de membrana acarreta na diminuição do fluxo de elétrons através da cadeia respiratória, aumentando a probabilidade de ocorrer a redução monoeletrônica do $\mathrm{O}_{2}$ em $\mathrm{O}_{2}{ }^{\circ-}$.

Igualmente, poder-se-ia esperar que mutações no mtDNA que afetem a velocidade do fluxo de elétrons através da CTE causariam também um desequilíbrio no estado redox mitocondrial em direção a mais oxidativa. É claro que, porque uma única célula pode conter de poucas centenas a alguns milhares de genomas mitocondriais, é comum existir uma variação na sequência das várias moléculas de mtDNA em uma mesma célula, fenômeno denominado heteroplasmia (BRANDON et al., 2006). O contrário, a homoplasmia, é quando todas as moléculas da população de mtDNA são iguais. De acordo com os dados experimentais existentes até o momento, para que uma mutação patogênica no mtDNA possa se manifestar funcionalmente, ela deve exceder um determinado limiar do total de genomas mitocondriais na célula, que é de 60 a 90 \% dependendo: i) do tipo da mutação, ii) e o tipo celular onde ela se manifesta (KRISHNAN et al., 2007).

À parte da dificuldade em investigar a validade do conceito do "ciclo vicioso", onde processos moleculares que produzem e consomem as EROs em mitocôndrias (figura 5), alguns estudos se propuseram a analisar somente um dos lados do ciclo, começando com a investigação do efeito de algumas mutações no mtDNA na bioenergética e no estado redox mitocondrial. De fato, células de indivíduos com a mutação patogênica 8993T>G em mtDNA apresentam uma maior produção de EROs (TROUNCE et al., 1994; MATTIAZI et al., 2004; PETROS et al., 2005). Do outro lado do ciclo, também há bons argumentos mostrando que a oxidação lenta e continua que ocorre nos tecidos aumentam a carga de mutações no mtDNA (MULLER-HOCKER et al., 1989). 


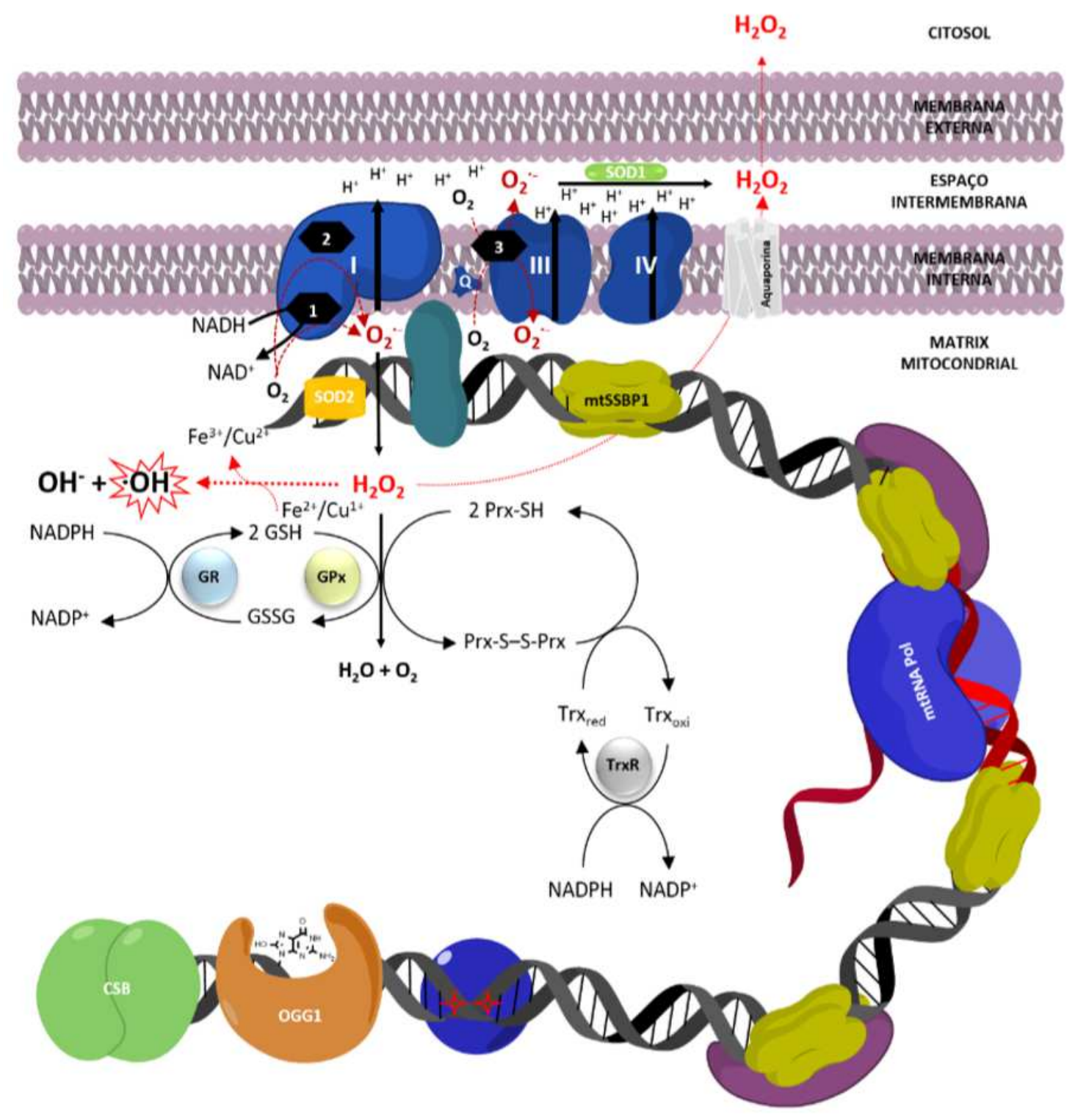

Figura 5 - Processos moleculares mitocondriais que produzem e consomem as EROs.

Os principais sítios de geração de $\mathrm{O}_{2}{ }^{*}$ são: 1 ) o sítio de oxidação de NADH no C-I através do grupo prostético FMN; 2) o sítio de ligação a UbQ no C-I; e 3) sítio Qo de oxidação da UbQH2. O radical $\mathrm{O}_{2}{ }^{*}$ formado é dismutado a $\mathrm{H}_{2} \mathrm{O}_{2}$ pela SOD2 na matriz mitocondrial, e pela SOD1 no espaço intermembranas. Por sua vez, o $\mathrm{H}_{2} \mathrm{O}_{2}$ é reduzido à água pela ação de dois sistemas enzimáticos: i) o GSH/GPx/GR e ii) Trx/Prx/TrxR. Ambos os sistemas, utiliza a cascata de reações de oxirredução NADPH, gerando $\mathrm{NADP}^{+}$. Caso $\circ \mathrm{H}_{2} \mathrm{O}_{2}$ não seja metabolizado, ele pode passar da matriz mitocondrial para o espaço intermembranas através de aquaporinas. Apesar do $\mathrm{H}_{2} \mathrm{O}_{2}$ ser relativamente inócuo, essa ERO pode reagir com $\mathrm{Fe}^{2+} / \mathrm{Cu}^{1+}$ gerando o ânion $\mathrm{OH}^{-}$e o altamente reativo radical $\bullet \mathrm{OH}$. Esse radical pode reagir com proteínas, lipídeos, RNA e DNA. Fonte: MUFTUOGLU, MORI, SOUZA-PINTO, 2014.

Como pode-se perceber, desde a descoberta de que as mitocôndrias apresentam um genoma próprio, começaram essas especulações se essas organelas possuíam mecanismos de reparo de DNA análogos aqueles que ocorrem no genoma nuclear. Experimentos pioneiros realizados por CLAYTON e colaboradores 
demonstraram que mitocôndrias de células de mamíferos eram incapazes de remover lesões induzidas por UV em seu genoma (CLAYTON et al., 1974). Como UV era o agente genotóxico modelo na época, isso levou a proposição de que mitocôndrias não continham vias de reparo de DNA. Essa visão era reforçada pelas observações de que: 1) o genoma dessa organela não codifica para nenhum gene envolvido no reparo do DNA (CHEN et al., 1996); 2) a presença de mais de uma cópia do genoma mitocondrial por organela (LIGHTOWLERS et al., 1997) e 3) o mtDNA apresenta uma maior taxa de mutação quando comparado com o nuclear (WALLACE, 2010).

No entanto, a retirada eficiente de purinas metiladas (LEDOUX et al., 1992), a presença da enzima UV endonuclease nas mitocôndrias (TOMKINSON et al., 1990), além dos estudos que verificaram que extratos protéicos mitocondriais são capazes de catalisar ligações de pontas livres em plasmídeos in vitro (THYAGARAJAN et al., 1996) indicam que o genoma dessas organelas está sujeito a outros tipos de reparo.

As mitocôndrias de mamíferos são muito eficientes na remoção de bases com pequenas modificações por meio de BER (BOHR et al., 2002). O mtBER se utiliza de um conjunto similar de proteínas do BER nuclear e o processo bioquímico pelo qual ocorre também é similar, a não ser pela presença da DNA polimerase $\gamma$, exclusiva das mitocôndrias e que está envolvida tanto na replicação como no reparo (DE SOUZAPINTO et al., 2004).

\subsubsection{BER MITOCONDRIAL (mtBER)}

A via BER foi a primeira via de reparo de DNA identificada em mitocôndrias de células de mamífero (ANDERSON e FRIEDBERG, 1980). O mtBER é iniciado por uma DNA glicosilase que remove especificamente a base danificada, gerando um sítio AP. Este sítio AP é processado por uma endonuclease AP, ou pela atividade AP liase associada. Esta atividade introduz um único filamento de DNA no sítio do dano que depois do processamento das extremidades, há inserção de um novo nucleotídeo pela DNA polimerase $\gamma$. A incisão é então selada pela DNA ligase, regenerando o DNA parental (DE SOUZA-PINTO et al., 2004).

No contexto da etapa de reconhecimento de BER, todas as DNA glicosilases localizadas no núcleo, foram também identificadas em mitocôndrias (AKBARI et al., 
2007). Porém, algumas DNA glicosilases mitocondriais podem existir em isoformas distintas das nucleares. Esse é o caso de UDG, cujas isoformas mitocondrial, UNG1, e nuclear, UNG2, diferem quanto ao sítio de iniciação de transcrição (NILSEN et al., 1997). Em células humanas também foram identificadas duas isoformas de OGG1, OGG1 $\alpha$ e OGG1 $\beta$ (NISHIOKA et al., 1999). Apesar de OGG1 $\alpha$ possuir uma sequência peptídica C-terminal que sinaliza fortemente para localização nuclear, essa isoforma pode ser encontrada tanto em núcleo quanto em mitocôndria - contudo, em menor concentração na última. Já OGG1ß é exclusivamente mitocondrial e, apesar de apresentar o sítio catalítico conservado com a isoforma $\alpha$, não apresenta atividade de DNA glicosilase in vitro (HASHIGUSHI et al., 2004).

Ambas as vias SP- e LP-BER ocorrem em mitocôndria (STIERUM et al., 1999; LIU et al., 2008). A etapa subsequente de BER é igualmente catalisada por APE1 tanto no núcleo quanto na mitocôndria (TELL et al., 2005). Outras enzimas que atuam no núcleo a fim de metabolizar terminais 3'ou 5' refratários à atividade da DNA polimerase e AP endonuclease também estão presentes na mitocôndria, como PNKP1 e TDP1 (MANDAL et al., 2012). Para a atividade de dRP liase e polimerase de DNA o mtBER depende exclusivamente da pol $\gamma$, a única DNA polimerase mitocondrial que atua tanto em SPBER quanto em LP-BER. Por fim, a etapa de ligação dos terminais 3'-OH do nucleotídeo incorporado e $5^{\prime}-\mathrm{PO}_{4}{ }^{2-}$ do nucleotídeo a jusante é efetuada pela LIG3, sem o auxílio da proteína XRCC1 (LAKSHMIPATHY e CAMPBELL, 2000), uma vez que esta não foi localizada em mitocôndrias de mamíferos até o momento.

Nesse contexto, pode-se perceber que várias das enzimas envolvidas no mtBER têm sido caracterizadas e em muitos casos, o mesmo gene que codifica enzimas nucleares também codifica enzimas mitocondriais, como tem sido demonstrado para a oxoguanina DNA glicosilase (OGG1) (DE SOUZA-PINTO et al., 2001).

Embora esta via tenha sido reconstituída in vitro e esteja bem fundamentada, ainda não está claro como o mtBER é regulado in vivo, gerando novas indagações que necessitam da compreensão de possíveis mecanismos de interações funcionais. 


\subsection{P53 E BER MITOCONDRIAL}

Além de suas funções primárias como ativador de transcrição, a proteína p53 está diretamente envolvida no reparo do DNA. Inicialmente um papel para p53 foi estabelecido no reparo por excisão de nucleotídeos (HANAWALT, 2002; HANAWALT et al., 2003), entretanto, resultados mais recentes demonstraram a participação direta de p53 no BER (CHEN et al., 2006).

BER é a maior via de reparo de DNA para pequenas alterações de bases como danos oxidativos e alquilações. OFFER (1999) demonstrou que um aumento da expressão de p53 induziu a síntese de reparo em sítios abásicos independente da atividade transcricional de p53, porque um mutante deficiente nesta atividade foi mais eficiente em estimular BER do que p53 selvagem (OFFER et al., 2001).

Outros estudos sugerem o papel de p53 controlando também as funções mitocondriais em resposta ao estresse (MOLL, ZAIKA, 2001). Após vários estímulos de morte, uma fração da proteína p53 transloca para a mitocôndria, o que provoca uma série de respostas que podem levar a morte celular (MIHARA et al., 2003). Porém p53 pode translocar para a organela independente de apoptose, o que sugere outro papel de p53 no interior da mitocôndria (ESSMANN et al., 2005).

Resultados recentes sugerem que esse papel pode estar relacionado com a manutenção da estabilidade do mtDNA, por meio de possíveis cooperações com vários fatores durante a síntese de DNA, como reportado por ACHANTA et al. (2005), DE SOUZA-PINTO et al. (2004), BAKHANASHIVILLI et al. (2008), WONG et al. (2009) e CANUGOVI et al. (2010). No entanto, como p53 participa de mtBER ainda não está claramente definido.

O grupo da profa. Nadja Cristhina de Souza Pinto, foi um dos primeiros a investigar uma participação direta de p53 em mtBER. Em experimentos comparando as atividades de BER in vitro em extratos de mitocôndria de fígado obtidos de camundongos com p53 selvagem, em heterozigose $\left(\mathrm{p} 53^{-/+}\right)$e knockout $\left(\mathrm{p} 53^{-/-}\right)$ observaram uma diminuição significativa na atividade de incorporação de nucleotídeos nos extratos dos camundongos heterozigotos e knockouts para p53. Esta deficiência foi complementada pela adição de p53 recombinante, sugerindo, portanto, que p53 modula mtBER (DE SOUZA-PINTO et al., 2004). Como mitocôndrias de mamíferos 
possuem apenas uma DNA polimerase descrita, a DNA polimerase $\gamma$, que participa tanto de replicação como de reparo, postularam que p53 interage funcionalmente com DNA pol $\gamma$, modulando assim sua atividade durante o BER (DE SOUZA-PINTO et al., 2004).

Além disso, em resultados obtidos em colaboração com o grupo do Dr. Vilhelm Bohr, do National Institute on Aging, USA, foi demonstrado que p53 pode modular a ligação de TFAM, um componente essencial do complexo nucleoproteico no qual se encontra o mtDNA (CANUGOVI et al., 2010). A ligação de TFAM ao DNA restringe o acesso de proteínas de reparo, e nesse contexto $\mathrm{p} 53$ pode funcionar facilitando esse acesso pela remoção de TFAM dos sítios de lesões no DNA.

Nesse sentido, esse estudo propôs investigar os possíveis mecanismos de interação funcional entre p53 e polimerase $\gamma$, bem como o papel de TFAM, na modulação do processo de mtBER em células humanas. 
OBJETIVOS 


\section{OBJETIVOS}

O objetivo deste estudo é compreender, molecularmente, a interação funcional entre p53 e polimerase $\gamma$ em mitocôndrias, em resposta a lesões no mtDNA. Para isso, foi proposto os seguintes objetivos específicos:

$\checkmark \quad$ Investigar se p53 e pol $\gamma$ interagem física e diretamente. Caso as duas proteínas não apresentem interação física direta, identificar possíveis proteínas acopladoras;

$\checkmark$ Investigar se a interação entre p53 e o fator de transcrição/replicação mitocondrial TFAM modula o papel de p53 na manutenção da integridade do genoma mitocondrial;

Investigar a translocação de p53 para a mitocôndria em resposta a agentes que causam danos no mtDNA e seu papel acoplado a outras proteínas envolvidas no reparo. 
MATERIAIS EMÉTOOOS 


\section{MATERIAIS E MÉTODOS}

\subsection{LINHAGENS CELULARES}

As seguintes linhagens celulares humanas foram utilizadas, de acordo com a especificidade de cada experimento: adenocarcinoma de colo de útero, HeLa (p53 instável, fenótipo p53 nulo); adenocarcinoma de próstata, PC-3 (p53\%); e embriônica

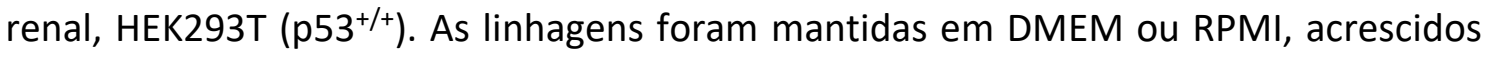
de soro fetal bovino e antibióticos, a $37^{\circ} \mathrm{C}$ em atmosfera úmida com $5 \%$ de $\mathrm{CO}_{2}$, por subcultivos periódicos.

\subsection{QUANTIFICAÇÃO DE PROTEÍNAS EM EXTRATOS CELULARES}

A determinação da concentração de proteínas em extratos celulares foi realizada usando o reagente Bradford (BioRad). Para isso 0,5 e $1 \mathrm{uL}$ do extrato proteico foi incubado durante $30 \mathrm{~min}$ com $190 \mathrm{uL}$ desse reagente. Em seguida, procedeu-se a leitura da absorbância em 562 nm e a concentração de proteínas nos extratos foram determinadas por comparação com a curva padrão feita para BSA (bovine serum albumin).

\subsection{ISOLAMENTO DE MITOCÔNDRIAS DE CÉLULAS EM CULTURA}

$\mathrm{O}$ isolamento foi realizado essencialmente como descrito por MAYNARD et al. (2010), com algumas modificações. As células foram lavadas em PBS e colhidas na fase log por raspagem e precipitadas por centrifugação (500 g por 12 minutos), onde foi adicionado um volume de tampão MSHE. Usando um homogeneizador de vidro foi realizada a lise mecânica das células, adicionando ao tampão MSHE digitonina 0,01 \%, versão modificada do método de GREENAWALT (1974). Para verificar a eficiência da homogeneização, foi adicionado $20 \mu \mathrm{L}$ de azul de tripan a alíquotas de $10 \mu \mathrm{L}$ do homogenato e inspecionadas no microscópio. Pelo menos $90 \%$ das células devem captar o corante. Depois da homogeneização, o processo de isolamento segue como descrito por MAYNARD et al. (2010). Neste ponto é importante verificar a pureza da preparação mitocondrial. Foi utilizado western blotting para sonda de contaminação nuclear, utilizando PCNA, uma proteína nuclear como um marcador de contaminação. 


\subsection{PREPARAÇÃO DOS EXTRATOS MITOCONDRIAIS}

Após obtenção da fração mitocondrial purificada, um extrato bruto foi preparado para os ensaios in vitro. $100 \mu \mathrm{L}$ do tampão de homogeneização (10 mM Tris$\mathrm{HCl} \mathrm{pH} \mathrm{7,8,} 200$ mM de $\mathrm{KCl}$ ) e $200 \mu \mathrm{L}$ do tampão de lise (10 mM de Tris- $\mathrm{HCl}$ pH 7,8, 600 $\mathrm{mM}$ de $\mathrm{KCl}, 2$ de mM EDTA, $2 \mathrm{mM}$ de DTT, 40\% de glicerol, 0,2 \% NP-40, 0,5 mM de PMSF, coquetel inibidor de protease $1 \mathrm{x}$ ) foram adicionados ao sedimento mitocondrial seguido por $1,5 \mathrm{~h}$ de incubação a $4{ }^{\circ} \mathrm{C}$ com agitação. O lisado foi sonicado a $5 \mathrm{~W}$ por 10 segundos 3 vezes no gelo, com intervalos de 30 segundos, e centrifugado a $20.800 \mathrm{~g}$ para precipitação de qualquer contaminação de DNA e de membranas. 0 sobrenadante contendo as proteínas purificadas foi dialisado overnight em tampão de diálise (25 mM de HEPES-KOH pH 8,0, 100 mM de KCl, 1 mM de EDTA, 1 mM de DTT, $12 \mathrm{mM}$ de $\mathrm{MgCl}_{2}, 17$ \% de glicerol). Após a diálise, o lisado foi centrifugado a $16.000 \mathrm{~g}$ por 10 minutos para precipitar a fração não-solúvel. Posteriormente, o sobrenadante foi aliquotado e a concentração de proteína foi quantificada usando o método de Bradford, com BSA como padrão. As alíquotas foram mantidas a $-80^{\circ} \mathrm{C}$.

\subsection{WESTERN BLOTTING}

A quantificação e os níveis de expressão das proteínas de interesse foram avaliados por western blotting. Todas as frações celulares obtidas foram separadas por SDS-PAGE (12 \%), utilizando técnicas padrão. As proteínas foram transferidas eletroforeticamente para uma membrana de PVDF (Millipore) por 90 minutos, a $90 \mathrm{~V}$. As membranas foram incubadas durante 1 hora em uma solução de bloqueio com $5 \%$ de albumina em TBS-T (tampão fosfato e 0,05 \% Tween 20). Em seguida, elas foram incubadas overnight com anticorpos primários, lavadas com TBS-T, e incubadas com os anticorpos secundários conjugados com HRP em temperatura ambiente, por 2 horas. As membranas foram então lavadas com TBS-T e incubadas com o kit ECL (GE Healthcare) por 5 minutos, no escuro. As bandas foram visualizadas expondo a membrana a filme de raios $X$ e quantificadas pelo programa Image $J^{T M}$. 


\subsection{EXCLUSÃO AO AZUL DE TRIPAN}

As células foram incubadas com azul de tripan 0,4 \% em PBS na proporção de 1:10 de corante:células. As células viáveis são impermeáveis ao corante, ao passo que a penetração do corante reflete o comprometimento da integridade da membrana plasmática. A viabilidade celular foi determinada por amostragem, calculada pela contagem em câmara de Neubauer, conforme a equação: $\mathrm{CV}(\%)=100 \times(\mathrm{NC} / \mathrm{NC}+\mathrm{C})$, em que: CV, células viáveis; NC, células não coradas e C, células coradas pelo azul de tripan. A viabilidade dos controles foi ajustada para $100 \%$.

\subsection{INDUÇÃO DE DANOS AO DNA USANDO RADIAÇÃO GAMA}

As células foram propagadas em placas de cultura de $60 \times 15 \mathrm{~mm}$ e dividiu-se 0 experimento em dois grupos experimentais: células controle e células irradiadas com radiação gama (IR). O primeiro grupo, referente às células controle, consiste de células que não foram irradiadas. Sendo assim, o meio de cultura dessas placas foi apenas trocado. $\mathrm{O}$ segundo grupo, referente às células tratadas, foi exposto a uma dose de 5 Gy (Gray) de radiação gama por meio de um irradiador Gammacell 220 (Atomic Energy of Canada Limited do Instituto de Pesquisas Energéticas e Nucleares, IPEN-CNEN/SP). Decorrido o tempo do tratamento, as células foram lavadas com PBS e acrescidas de um novo meio de cultura completo. Em seguida, subdividiu-se o conjunto das células tratadas, que permaneceram a $37{ }^{\circ} \mathrm{C}$ em estufa umidificada com atmosfera de $5 \%$ de $\mathrm{CO}_{2}$ por períodos de recuperação. Para o grupo das células que não foram irradiadas, apenas houve a troca do meio por solução de PBS. Transcorrido esse tempo, retirou-se o PBS e acrescentou-se meio de cultura completo, mantendo-se este meio em contato com as células a $37{ }^{\circ} \mathrm{C}$ em estufa umidificada com atmosfera de $5 \%$ de $\mathrm{CO}_{2}$. Posteriormente as células foram coletadas para o isolamento mitocondrial a fim de verificar o nível proteico no interior das mitocôndrias, bem como para experimentos de co-imunoprecipitação.

\subsection{LIGAÇÃO COVALENTE DOS ANTICORPOS À PROTEÍNA A/G AGAROSE}

As reações para a ligação covalente dos anticorpos à proteína $A / G$ agarose (Santa Cruz Biotecnology) utilizaram $200 \mu \mathrm{L}$ da resina. Para isso a mesma foi lavada 2 
vezes com PBS gelado, e suspensa em igual volume desse tampão. A esse volume foram adicionados $200 \mu \mathrm{L}$ de tampão de ligação ( $1 \mathrm{mg} / \mathrm{ml}$ de BSA, em PBS) seguida por incubação, com agitação a $4{ }^{\circ} \mathrm{C}$, durante 10 minutos. Ao final desse tempo a amostra foi centrifugada ( $9.000 \mathrm{~g}$ durante 15 minutos a $4{ }^{\circ} \mathrm{C}$ ) sendo o sobrenadante descartado. Ao volume correspondente ao precipitado (cerca de $100 \mu \mathrm{L}$ ) foi adicionado igual volume de tampão de ligação contendo $30 \mathrm{uL}$ de anticorpo, sendo a mistura posteriormente incubada com agitação a $4^{\circ} \mathrm{C}$, durante 1 hora. Passado esse tempo a amostra foi centrifugada ( $9.000 \mathrm{~g}$ durante 15 minutos a $\left.4{ }^{\circ} \mathrm{C}\right)$ e o sobrenadante descartado. Procedeu-se a resuspensão do precipitado em tampão de ligação, seguida por nova incubação com agitação a $4{ }^{\circ} \mathrm{C}$, durante 5 minutos. Ao final dessa etapa a amostra foi centrifugada ( $9.000 \mathrm{~g}$ durante 15 minutos a $4{ }^{\circ} \mathrm{C}$ ) e novamente lavada com PBS gelado e foi posteriormente incubada com nova agitação a $4{ }^{\circ} \mathrm{C}$, durante 5 minutos com o tampão de lavagem (0,2 M de trietanolamina em PBS). Ao final desse tempo a amostra foi centrifugada e suspensa em $100 \mu \mathrm{L}$ desse tampão. Igual volume de solução de dimetil pimelimidato (DMP) (1 $\mathrm{mL}$ de solução de DMP $13 \mathrm{mg} / \mathrm{ml}+1 \mathrm{ml}$ de tampão de lavagem) foi adicionado e a amostra incubada com agitação a $4{ }^{\circ} \mathrm{C}$, durante 30 minutos, sendo essa etapa repetida por mais uma vez. Transcorrido esse tempo a amostra foi centrifugada e resuspendida em $100 \mu \mathrm{L}$ de $50 \mathrm{mM}$ de etanolamina, seguida por incubação com agitação a $4{ }^{\circ} \mathrm{C}$, durante 5 minutos, seguida de uma nova lavagem com PBS gelado. Em etapa final, para a retirada do excesso de anticorpo não ligado, foram realizadas duas incubações da amostra com glicina (1 M pH 3) durante 10 minutos, com agitação. Uma vez realizada a etapa de ligação covalente do anticorpo à proteína $\mathrm{A} / \mathrm{G}$ agarose, esse produto foi estocado a $4{ }^{\circ} \mathrm{C}$, sendo usadas cerca de $30 \mu \mathrm{L}$ desse material em cada reação de co-imunoprecipitação.

\subsection{SILENCIAMENTO GÊNICO}

O silenciamento da expressão dos genes escolhidos foi obtido pela transfecção de células HEK293T com vetores plasmidiais expressando short hairpin RNAs (shRNAs) específicos para cada gene (Hush shRNA plasmid 29-mer, OriGene Technologies). Este sistema de silenciamento gênico consiste de um conjunto de 1 vetor controle vazio (sem a sequência codificadora do shRNA), 1 vetor controle com a sequência 
codificadora embaralhada e 4 vetores com diferentes sequências codificadoras de shRNA contra o alvo específico. Dessa forma, foram gerados inicialmente seis linhagens transfectadas para cada proteína cuja expressão deseja-se diminuir (p53), resultando num total de 12 linhagens. Para a geração das linhagens celulares silenciadas, células HEK293T mantidas em cultura com meio completo tiveram o meio removido e, então, foram lavadas com PBS estéril. Em seguida, a cultura foi tratada por 2 minutos com tripsina pré-aquecida a $37^{\circ} \mathrm{C}$ até as células se desprenderem. As células foram ressuspendidas em meio completo, contadas em câmara de Neubauer, semeadas (3,0 $\times 10^{5}$ células/poço) em placas de 6 poços, em um volume de $2 \mathrm{~mL}$ de meio completo e mantidas em incubadora por 24 horas (ou até atingir $50 \%$ de confluência). A preparação do vetor plasmidial e o procedimento para a transfecção foram realizados 24 horas após o plaqueamento das células, seguindo as recomendações do fabricante. Os diferentes vetores foram inseridos nas células selvagens por meio do uso do reagente lipofílico Lipofectamina 2000 (Invitrogen). Durante o procedimento de transfecção, para cada vetor utilizado foram preparados dois tubos de reação. As soluções dos tubos 1 e 2 foram combinadas, misturadas cuidadosamente e incubadas por 20 minutos em temperatura ambiente. 0 meio de cultura das células plaqueadas foi trocado por meio DMEM sem soro e antibióticos, e a solução resultante da mistura dos dois tubos foi adicionada a cada poço correspondente. Em seguida, as placas com as culturas recém transfectadas foram transferidas para a incubadora, nas condições padrão. Doze a dezoito horas após a adição dos vetores, o meio de incubação foi suplementado com a adição de soro fetal bovino e antibiótico suficiente para atingir a mesma concentração do meio completo. Quando atingiram a confluência, as células foram repicadas e transferidas para garrafas de cultura contendo meio completo e $0,5 \mu \mathrm{g} / \mathrm{mL}$ do antibiótico de seleção, a puromicina. A partir deste ponto, as culturas transfectadas foram mantidas nessas condições. Uma vez que os vetores plasmidiais utilizados codificam as proteínas fluorescentes verde (GFP) e vermelha (RFP), a eficiência das transfecções foi estimada pela visualização das culturas em microscópio de fluorescência Nikon Eclipse TE300 Inverted Fluorescence Microscope. Apenas as culturas que apresentavam mais de $50 \%$ das células expressando as proteínas fluorescentes foram mantidas. 


\subsection{SELEÇÃO DE LINHAGENS KNOCKDOWN}

Os vetores plasmidiais usados para a transfecção contêm uma sequência que codifica para a enzima puromicina- $\mathrm{N}$-acetil transferase, a qual confere resistência ao antibiótico puromicina e está sob o controle de um promotor forte, o SV4O early promoter. Dessa maneira, ao adicionar puromicina ao meio de cultura apenas as células que incorporaram o plasmídeo e expressam seus genes sobreviverão. Este procedimento garante a seleção de células nas quais a integração e expressão dos genes de interesse ocorrem de forma eficiente, nesse caso o shRNA alvo-específico. Para selecionar células com expressão estável do shRNA por tempo prolongado foi feito uso contínuo do antibiótico, cujas concentrações variaram gradualmente de 0,5 $\mu \mathrm{g} / \mathrm{mL}$ (em passagens iniciais) até $2,0 \mu \mathrm{g} / \mathrm{mL}$ após um número maior de repicagens da cultura, mantendo a pressão seletiva.

\subsection{AVALIAÇÃO DA PORCENTAGEM DE SILENCIAMENTO}

Com o objetivo de avaliar a eficiência do silenciamento gênico obtido pelo uso dos vetores expressando os shRNAs específicos, quantificou-se as proteínas p53 e TFAM pela metodologia de western blotting.

\subsection{SELEÇÃO CLONAL}

Após as avaliações do grau de silenciamento por shRNA, descritas nos tópicos anteriores, foram selecionadas linhagens clonais para cada produto gênico em estudo. A seleção clonal é necessária para obtenção de uma população geneticamente homogênea, uma vez que o plasmídeo de silenciamento integra no genoma nuclear das células transfectadas de forma aleatória. Isso reduz derivações genéticas na população e, portanto, contribui para diminuir as variações experimentais. A técnica utilizada neste trabalho para a geração dos clones consistiu em semear as células em uma densidade de 1 célula/poço em placa de 96 poços e cultivá-las em meio completo seguindo o procedimento padrão. Dessa maneira, espera-se que alguns poços recebam somente uma única célula capaz de se multiplicar e gerar uma colônia. As linhagens celulares que apresentaram maiores índices de silenciamento gênico foram selecionadas, juntamente com seu par controle, e submetidas ao procedimento de 
seleção clonal, como descrito anteriormente. As placas de 96 poços contendo as células foram mantidas em incubadora por cerca de 10 dias. Ao final desse período as culturas foram observadas ao microscópio óptico, e os poços que apresentaram colônias individualizadas foram expandidos. Os clones obtidos foram cultivados e, novamente, avaliados quanto ao silenciamento gênico por meio de western blotting, como já descrito anteriormente.

\subsection{CULTIVO E MANUTENÇÃO DE CÉLULAS KNOCKDOWN PARA TFAM}

As células HEK293T TFAM KD foram cultivadas em meio DMEM completo (10\% soro fetal bovino e antibióticos - estreptomicina/penicilina) e suplementado com 100 $\mathrm{ug} / \mathrm{ml}$ de piruvato e uridina. Visto que células TFAM KD apresentaram redução no número de cópias de mtDNA, afetando o metabolismo aeróbico, suplementou-se o meio com piruvato. Além disso, a suplementação com uridina visa fornecer substrato para a biossíntese de timinas, visto que a biossíntese de ácidos nucléicos também se encontra comprometida. As células foram plaqueadas com materiais estéreis, e incubadas em estufas umidificadas, com atmosfera de $5 \% \mathrm{CO}_{2}$, a $37^{\circ} \mathrm{C}$ até atingir $80 \%$ de confluência. Estoques de passagens baixas das células TFAM KD foram realizados, em meio contendo $20 \%$ de SFB em meio DMEM, na presença de $10 \%$ de DMSO (dimetilsulfóxido). Estoques de células foram mantidos em nitrogênio líquido.

\subsection{TRANSFECÇÃO DE HEK293T COM ShRNA GENE-ESPECÍFICO}

A expressão gênica de TFAM foi reduzida por meio da transfeç̧ão de células HEK293T com plasmídeos codificando um shRNA (smallhairpin RNA de 29 nucleotídeos) específico (OriGene) e contendo gene de resistência a puromicina. Foram utilizadas quatro sequências específicas, e um controle negativo, contendo uma sequência que não reconhece nenhum gene humano anotado. Para a transfecção utilizou-se lipofectamina (Invitogen), e 1 ug do plasmídeo shRNA, seguindo-se as recomendações do protocolo do fabricante. Após a transfecção, as células foram cultivadas em meio DMEM, sem soro fetal bovino (SFB) e puromicina, por 12 horas, em estufa com $5 \%$ de $\mathrm{CO}_{2}$. Posteriormente, adicionou-se $10 \%$ de SFB e $1 \mathrm{ug} / \mathrm{ml}$ de puromicina. A pressão de seleção com puromicina foi realizada por 2 semanas, 
trocando o meio durante o período quando esse ficava saturado. Em seguida, as células selecionadas foram transferidas para garrafas, plaqueando-se aproximadamente $3 \times 10^{6}$ células, mantendo-se a pressão seletiva com $1 \mathrm{ug} / \mathrm{mL}$ de puromicina, e acrescentando $100 \mathrm{ug} / \mathrm{mL}$ de piruvato e uridina ao meio de cultura.

\subsection{QUANTIFICAÇÃO DE DNA}

A concentração de DNA nas soluções foi estimada por espectrofotometria a 260 nm, em aparelho Nanodrop 1000 (Thermo Fisher Scientific Inc.).

\subsection{ISOLAMENTO DE DNA TOTAL E ANÁLISE QUALITATIVA DO NÚMERO DE CÓPIAS E DELEÇÕES NO DNA MITOCONDRIAL}

O DNA das amostras foi isolado por meio do Kit DNeasy Blood \& Tissue (Qiagen) e de acordo com as instruções do fabricante. Para a quantificação do número de cópias do mtDNA comparado ao nDNA, foi usado o q-PCR (real time quantitative polimerase chain reaction) com o Kit Power SYBR Green PCR Master Mix (Applied Biosystem), em um termociclador 7500 Real Time PCR System (Applied Biosystem). As reações foram feitas em volume final de $25 \mu \mathrm{L}$, contendo $12,5 \mu \mathrm{L}$ de $2 X$ SYBR Green PCR Master Mix, primers $5 \mathrm{pmol}$ cada e $20 \mathrm{ng}$ de DNA total. Nas reações foi usado o programa padrão para qPCR, a saber: um ciclo de $95{ }^{\circ} \mathrm{C}$ por 10 minutos, 40 ciclos de 95 ${ }^{\circ} \mathrm{C}$ por 15 segundos e $60{ }^{\circ} \mathrm{C}$ por 1 minuto. Após a amplificação foi realizada uma curva de dissociação para verificar a especificidade dos primers utilizados, ou seja, a formação de um único produto alvo. Os seguintes genes foram escolhidos para a análise por qPCR: HPRT (hipoxantina fosforibosil transferase, gene nuclear de cópia única) para controle de carregamento do DNA nuclear, gene ND1 (NADH desidrogenase subunidade mitocondrial 1) para medida do número de cópias de mtDNA e gene ND4L (NADH desidrogenase subunidade mitocondrial $4 \mathrm{~L}$ ) para medida do número relativo de deleções no mtDNA. ND4L foi escolhido como um marcador de deleção devido à grande frequência de deleções na região na qual esse gene está localizado, em populações humanas, em oposição à baixa frequência de deleções na região contendo o gene ND1 (DAMAS et al., 2012). As sequências dos primers (Invitrogen) usados são apresentadas na tabela 1. 
Tabela 1 - Primers utilizados para qPCR para o número de cópias de mtDNA.

\begin{tabular}{|c|c|c|c|c|}
\hline Gene & Nome do Gene & & Sequência & NCBI RefSeq \\
\hline \multirow{2}{*}{$M T-N D 1$} & \multirow{2}{*}{$\begin{array}{l}\text { mitochondrially encoded } \\
\text { NADH } 1 \text { dehydrogenase }\end{array}$} & Senso & ACT ACG CAA AGG CCC CAA CG & \multirow{2}{*}{ NC_012920.1 } \\
\hline & & Antissenso & GAG CTA AGG TCG GGG CGG TG & \\
\hline \multirow{2}{*}{$M T-N D 4 L$} & \multirow{2}{*}{$\begin{array}{l}\text { mitochondrially encoded } \\
\text { NADH 4L dehydrogenase }\end{array}$} & Senso & АCC CСТ CAA CAC CCA СТC ССТ CTТ & \multirow{2}{*}{ NC_0111137.1 } \\
\hline & & Antissenso & TAG GCC CAC CGC TGC TTC GC & \\
\hline \multirow{2}{*}{$H P R T$} & \multirow{2}{*}{$\begin{array}{c}\text { hypoxanthine } \\
\text { phosphoribosyltransferase }\end{array}$} & Senso & TGA CAT GTG CCG CCT GCG AG & \multirow{2}{*}{ NC_000023.11 } \\
\hline & & Antissenso & GTG GTC GCT TTC CGT GCC GA & \\
\hline
\end{tabular}

Fonte: autor da tese.

A partir dos dados de cycle threshold (CT) para cada par de primers, já padronizado anteriormente, foi calculada a eficiência de amplificação dos genes, conforme descrito a continuação, em que slope é a inclinação da reta resultante do gráfico obtido de CT x massa de DNA, e E corresponde à eficiência do primer.

$$
\text { E primer }=10^{-1 / \text { Slope }}
$$

A amplificação relativa para cada uma das amostras foi obtida pelo uso da equação (2). A análise do número relativo de cópias de mtDNA foi feita calculando a eficiência de amplificação de uma sequência mitocondrial (ND1) relativa à amplificação de uma sequência nuclear (HPRT). Já para o número de deleções no mtDNA foi usada a amplificação da sequência mitocondrial raramente deletada (ND1) relativa à amplificação da sequência mitocondrial frequentemente deletada (ND4L).

$$
\text { Amplificação Relativa }=\frac{E_{m t D N A}^{\left(C_{T \text { controle-mtDNA }}-C_{\text {Tamostra-mtDNA }}\right)}}{E_{H P R T}^{\left(C_{T \text { controle-HPRT-C }}-C_{\text {Tamostra-HPRT })}\right.}}
$$

\subsection{ANÁLISE DE LESÕES EM mtDNA POR XL-PCR}

Após o isolamento do DNA por meio do Kit DNeasy Blood \& Tissue (Qiagen), a quantidade de lesões em DNA foi quantificada por PCR de longa extensão (XL-PCR) utilizando rTth polimerase Kit XL (Life Technology), de acordo com o protocolo do fabricante, e metodologia e primers (5'-TGA GGC CAA ATA TCA TTC TGA GGG GC-3' sense; 5'-TTT CAT CAT GCG GAG ATG TTG GAT GG-3' antisense). As reações foram 
feitas em volume final de $50 \mu \mathrm{L}$, contendo $15 \mu \mathrm{L}$ de tampão 3,3X XL PCR, 2,6 $\mu \mathrm{L}$ de 25 $\mathrm{mM}$ de acetato de magnésio (concentração final 1,3 mM), 0,5 $\mu \mathrm{L}$ de $10 \mathrm{mg} / \mathrm{mL}$ de BSA (concentração final de 0,1 mg/mL), $2 \mu \mathrm{L}$ de $10 \mu \mathrm{M}$ primer cada (concentração final de $20 \mathrm{pmol}$ ), $4 \mu \mathrm{L}$ de 2,5 mM dNTP (concentração final de $200 \mathrm{nM}$ ), $5 \mu \mathrm{L}$ de 0,2 U/ $\mu \mathrm{L} \mathrm{rTth}$ DNA polimerase $X L(1 \mathrm{U})$ e $5 \mu \mathrm{L}$ de $3 \mathrm{ng} / \mu \mathrm{L}$ DNA (concentração final de $15 \mathrm{ng}$ ). Uma etapa de anelamento de 30 segundos a $64{ }^{\circ} \mathrm{C}$ e um aumento na etapa de desnaturação para 30 segundos foram adicionadas aos parâmetros do ciclo. Fragmentos mitocondriais grandes (16 Kb) das células normais e knockdown foram amplificados e a eficiência de amplificação foi comparada para estimar a quantidade de lesões bloqueadoras de polimerases no mtDNA. Para normalização da quantidade de DNA utilizada em cada amostra foi usada a amplificação de um fragmento pequeno (200 pb) (ND1) do mtDNA. Os produtos da reação foram submetidos à separação eletroforética em gel de agarose $1 \%$ e a corrida procedeu-se a $100 \mathrm{~V}$ durante $4 \mathrm{~h}$ em tampão TAE (40 $\mathrm{mM}$ de Tris-acetato $\mathrm{pH}$ 7,8, $1 \mathrm{mM}$ de EDTA). O gel foi corado em $2 \mathrm{mg} / \mathrm{L}$ de brometo de etídeo por 30 min e lavado em água deionizada por 10 minutos. As imagens foram captadas em ImageQuant 300 (GE Life Sciences), usando o Typhoon 8600 scanner (GE LifeSciences), e analisadas em ImageJ.

\subsection{ANÁLISE ESTATÍSTICA}

Os resultados foram expressos como média \pm SEM. As análises de significância foram realizadas por two-way ANOVA, seguido de teste de Bonferroni ou de Dunnet para comparações entre os grupos múltiplos. Um teste $t$ pareado foi aplicado para comparar os grupos. Valores de $p<0,05$ foram considerados estatisticamente significativos. 
RESULTADOS 


\section{RESULTADOS}

\subsection{ANÁLISE DA PUREZA DOS EXTRATOS MITOCONDRIAIS}

Como a proteína p53 pode estar localizada tanto no núcleo quanto na mitocôndria e citosol, inicialmente verificou-se a pureza de nosso fracionamento celular. Isso se torna necessário, pois o enriquecimento com uma contaminação nuclear muito grande na fração mitocondrial consistiria em um artefato de mascarar suas funções e atividades nas frações mitocondriais.

Para isso, foi realizado um western blotting contendo amostras de cada uma das frações celulares imunodectadas para proteínas marcadoras. Foram utilizados para sonda: PCNA, uma proteína nuclear, e COX 4, uma proteína exclusivamente mitocondrial, para caracterizar as respectivas frações.

Como pode ser observado na figura 6 , nas frações mitocondriais houve a imunodetecção de COX 4 e também de PCNA, porém em menor nível do que o detectado nas frações nucleares e citosólica de cada linhagem celular. Isso mostra que o fracionamento celular resultou num enriquecimento significativo da fração mitocondrial (figura 6, painéis $A, B$ e C). Nesse sentido, uma vez que confirmou-se que as frações mitocondriais estavam enriquecidas, em todas as linhagens celulares, essas foram usadas para os demais experimentos que serão descritos posteriormente. Adicionalmente, a cada novo isolamento mitocondrial, essa etapa de verificação foi realizada. 
(A)

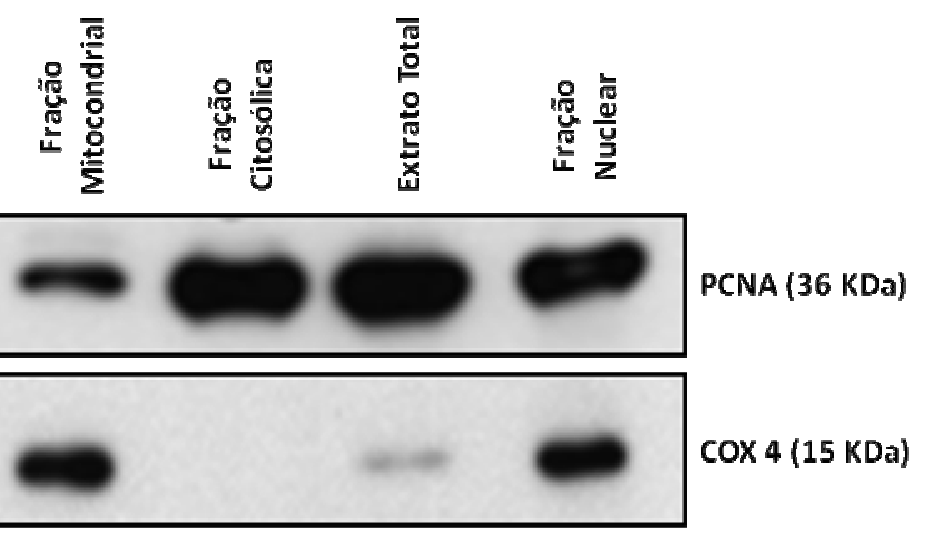

(B)

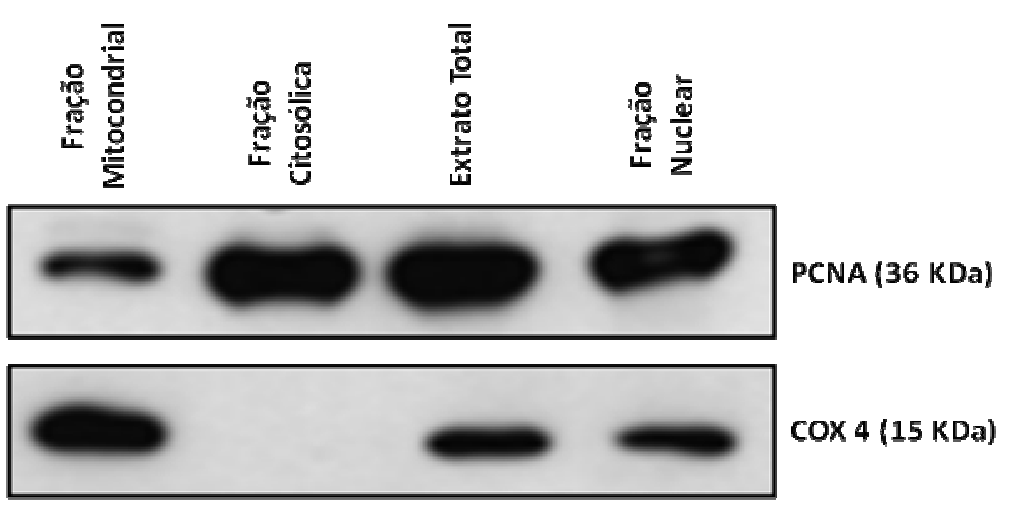

(C)

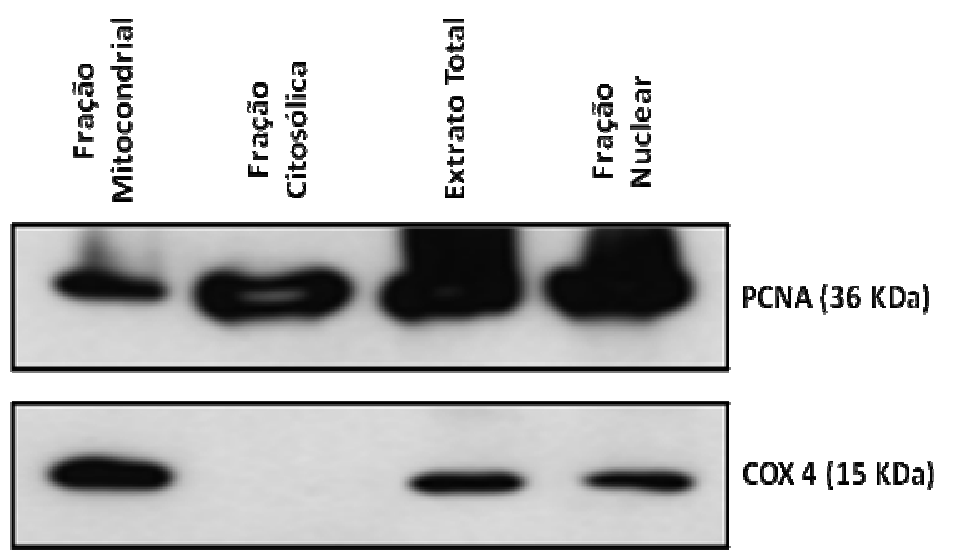

Figura 6 - Análise da pureza das frações celulares por meio de imunodetecção de PCNA e COX 4.

Foram utilizados anticorpos contra PCNA, uma proteína nuclear, e COX 4, uma proteína exclusiva mitocondrial, para caracterizar as respectivas frações. Para esses westerns blotting, foram utilizadas 20 ug das diferentes frações celulares obtidas das linhagens HEK293T (A), PC-3 (B) e HeLa (C). A pureza das frações foi analisada por meio da mínima expressão de PCNA nos extratos mitocondriais em contraste com COX 4. Fonte: autor da tese. 
Por outro lado, a imunodetecção de $\operatorname{coX} 4$ em frações nucleares deve-se ao fato de que o protocolo utilizado nesse estudo prioriza a obtenção de frações mitocondriais puras. O que considerou-se como fração nuclear, embora seja composto predominantemente por núcleos, não está livre de contaminações com frações mitocondriais e/ou citoplasmáticas.

\subsection{ANÁLISE DA EXPRESSÃO DE p53 NAS LINHAGENS CELULARES}

Para a realização de experimentos de interação proteica com extratos mitocondriais escolheu-se utilizar três linhagens humanas com status de p53 distintos. A linhagem HeLa apresenta um fenótipo p53-nulo devido à instabilidade da proteína; a linhagem PC-3 possui uma mutação em heterozigose e a linhagem HEK293T possui p53 wild-type. Nesse sentido, verificou-se a expressão de p53 em condições fisiológicas nas diferentes linhagens celulares. Para isso, foi realizado um western blotting contendo amostras de extratos celulares totais imunodectadas para a proteína p53.

Como pode ser observado na figura 7, a linhagem celular HEK293T possui uma expressão maior de p53 quando comparada a expressão diminuída na linhagem PC-3 ou nenhuma expressão na linhagem HeLa, caracterizando, portanto, diferentes status de p53 nessas linhagens. Vale a pena ressaltar que inicialmente utilizou-se outra linhagem celular wild-type para p53, a LNCaP. Porém, teve-se dificuldades técnicas em manter essas culturas no laboratório, e escolhemos HEK293T para substituí-la, pois possuem os mesmos padrões metabólicos e um subcultivo estabelecido. 


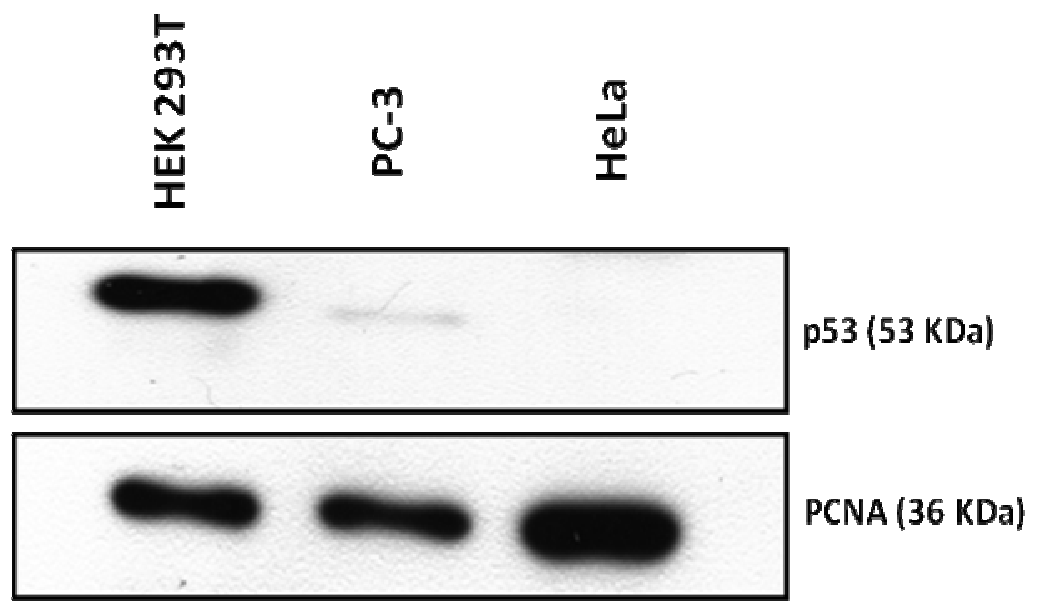

Figura 7 - Análise da expressão de p53 em extratos celulares.

A expressão de p53 foi avaliada por western blotting com anticorpo anti-p53 em extratos totais obtidos das linhagens celulares HEK293T, PC-3 e HeLa. Para esses ensaios, 10 ug de proteína total foram utilizadas. A imunodetecção com o anticorpo anti-PCNA mostra que quantidades aproximadas de proteínas foram analisadas nas diferentes amostras. Fonte: autor da tese.

Essa caracterização é primordial pelo fato de nossos estudos focarem na importância dessa proteína no controle das funções mitocondriais em resposta ao estresse, e seu papel na relação com a manutenção da estabilidade do mtDNA, por meio de possíveis cooperações com vários fatores durante a síntese e reparo do DNA, que pode estar comprometida na deficiência dessa proteína.

\subsection{ANÁLISE DA EXPRESSÃO DE TFAM NAS LINHAGENS CELULARES}

O fator de transcrição mitocondrial A (TFAM) pertence ao grupo das proteínas de alta mobilidade, apresentando um importante papel para a replicação, transcrição e estrutura/organização do DNA mitocondrial (mtDNA). O mtDNA está organizado em um complexo nucleoproteico, conhecido como nucleoide, do qual TFAM é o principal componente proteico, empacotando o DNA tal como uma histona. Alguns resultados experimentais sugerem que o empacotamento do mtDNA por TFAM é um importante meio de proteger o mtDNA da formação de lesões oxidativas por espécies reativas de oxigênio (EROs), apesar de essa hipótese não ter sido bem comprovada ainda. 
Como p53 interage com TFAM in vitro e pode modular sua associação com o mtDNA, inicialmente estudou-se a relação entre o status de p53 e a expressão dessa proteína.

Como mostra a figura 8, há uma diferença bastante significativa na expressão de TFAM entre as diferentes linhagens celulares, sugerindo que os níveis de expressão de TFAM estão modificados em células com diferentes status de p53. Enquanto essa observação pode indicar que a expressão de TFAM poderia ser modificada em resposta aos baixos níveis de p53, talvez como um mecanismo compensatório, deve-se considerar que essas três linhagens possuem muitas outras diferenças metabólicas e de expressão gênica. 
(A)

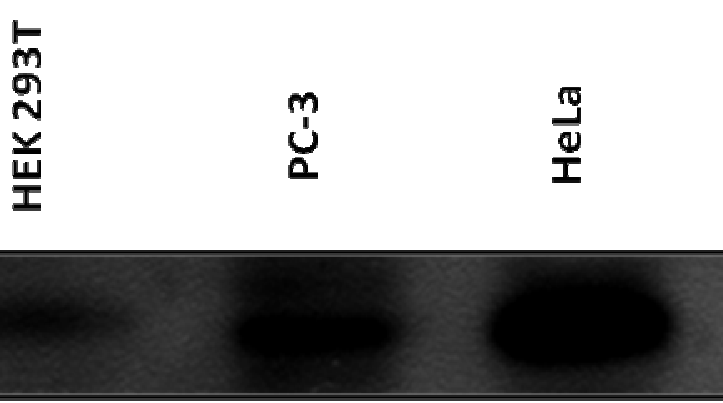

TFAM (25 KDa)

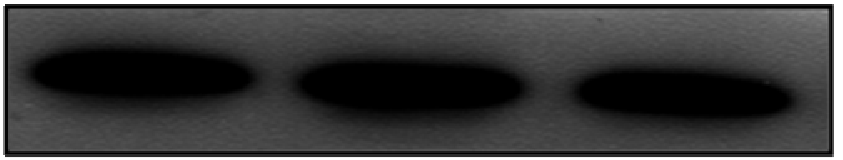

PCNA (36 KDa)

(B)

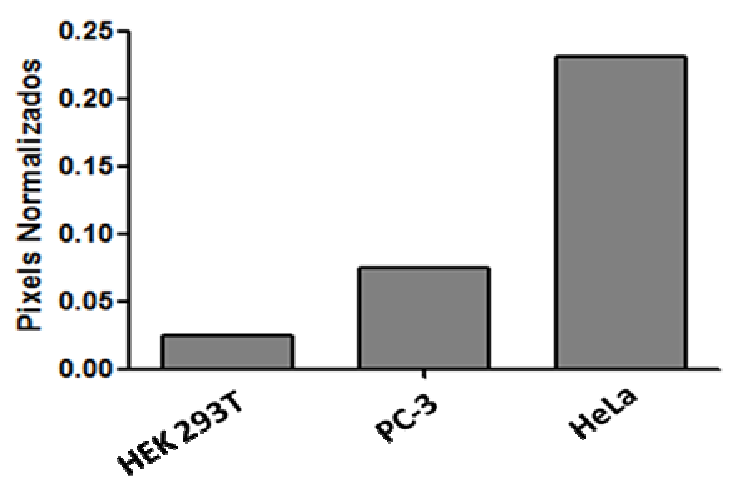

Figura 8 - Análise da expressão de TFAM em extratos celulares.

A expressão de TFAM foi avaliada por western blotting com anticorpo anti-TFAM em extratos totais obtidos das linhagens celulares HEK293T, PC-3 e HeLa (A). Para esses ensaios, 30 ug de proteína total foram utilizadas. A imunodetecção com o anticorpo anti-PCNA mostrou que quantidades similares de proteínas foram analisadas nas diferentes amostras. Após imunodetecção, as bandas referentes a TFAM e PCNA foram quantificadas pelo programa ImageJ ${ }^{T M}$ e construído um histograma com a razão entre os valores de área relativos a TFAM e PCNA (B). Fonte: autor da tese.

\subsection{ANÁLISE DA EXPRESSÃO DE POL $\gamma$ NAS LINHAGENS CELULARES}

A polimerase $\gamma(\mathrm{pol} \gamma)$ é uma DNA polimerase exclusiva da mitocôndria e é responsável tanto pela replicação quanto pelo reparo do mtDNA. A holoenzima é um complexo heterodimérico, composto por uma subunidade catalítica de 146 KDa codificada pelo gene PolG, que possui domínios com atividades de polimerase, exonuclease e liase; e por uma subunidade acessória de 55 KDa codificada pelo gene 
PolG2, que está relacionada com a processividade da enzima. A manutenção do DNA mitocondrial é criticamente dependente de pol $\gamma$, já que as mutações em PolG e PolG2 são causas importantes de algumas doenças humanas.

Como os resultados anteriores do grupo mostraram uma interação funcional entre pol $\gamma$ e p53, foi proposto testar se a expressão de pol $\gamma$ também é impactada pela expressão de p53.

Na figura 9, há uma diferença bastante significativa na expressão de pol $\gamma$ entre as diferentes linhagens celulares, sugerindo que os níveis de expressão de pol $\gamma$ foram modificados em células com diferentes status de p53, a mesma situação que ocorre com a expressão de TFAM. Enquanto essa observação pode indicar que a expressão de pol y poderia ser modificada em resposta aos baixos níveis de $p 53$, talvez como um mecanismo compensatório, assim como TFAM, deve-se considerar que essas três linhagens possuem muitas outras diferenças metabólicas e de expressão gênica. 
(A)

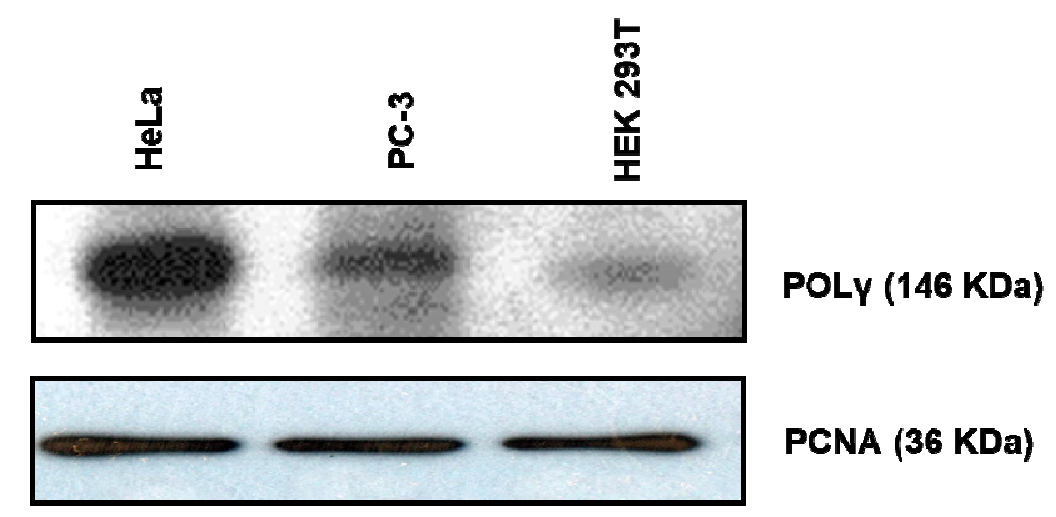

(B)

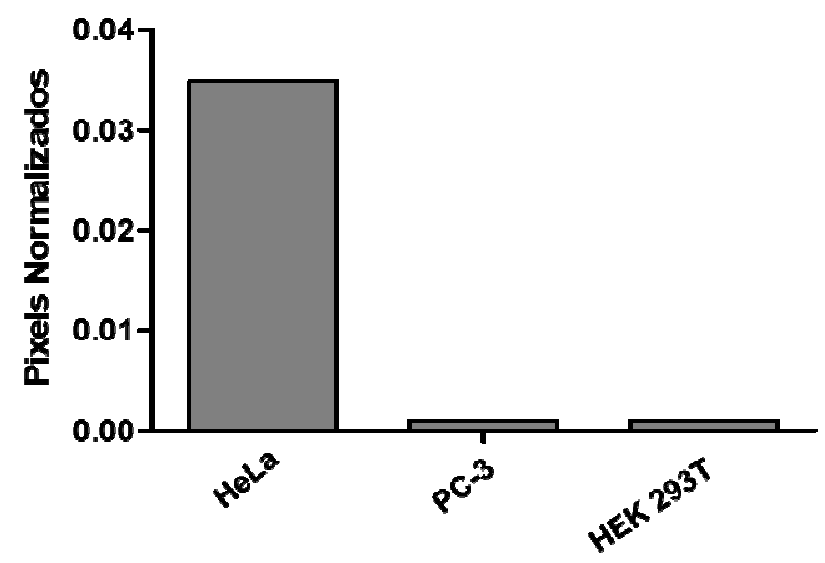

\section{Figura 9 - Análise da expressão de pol $\gamma$ em extratos celulares.}

A expressão de pol $\gamma$ foi avaliada por western blotting com anticorpo anti-pol $\gamma$ em extratos totais obtidos das linhagens celulares HEK293T, PC-3 e HeLa (A). Para esses ensaios, 30 ug de proteína total foram utilizadas. A imunodetecção com o anticorpo anti-PCNA mostrou que quantidades similares de proteínas foram analisadas nas diferentes amostras. Após imunodetecção, as bandas referentes a pol $\gamma$ e PCNA foram quantificadas pelo programa Image ${ }^{T M}$ e construído um histograma com a razão entre os valores de área relativos a pol $\gamma$ e PCNA (B). Fonte: autor da tese.

\subsection{ANÁLISE DA EXPRESSÃO DE TFAM EM CÉLULAS KNOCKDOWN PARA p53}

Como as diferentes linhagens celulares utilizadas nesse estudo não são isogênicas, é possível que a diferença na expressão de TFAM resulte de outras alterações no controle da expressão gênica, independentes do estado de p53 da linhagem. Desta forma, para testar se o status de p53 influi diretamente na expressão de TFAM, testou-se os níveis desta proteína em células HEK293T nas quais os níveis de p53 foram alterados pela expressão constitutiva de um RNA de interferência. 
Para a confecção dessas linhagens knockdowns foram realizadas transfecções de células HEK293T com plasmídeos que codificam short hairpin RNAs (shRNA) para o gene TP53, onde esses shRNAs suprimem a expressão gênica ao longo de um período prolongado por expressar continuamente um RNA duplex que quando processado gera siRNAs homólogos ao RNA alvo. O sistema de transfecção utilizado foi o da empresa OriGene Technologies, o qual se baseia no uso de plasmídeo de silenciamento retroviral (pRS), que contém gene de resistência a puromicina e um promotor de pequeno RNA nuclear U6 para dirigir a expressão da sequência de hairpin inserida e efetivar o silenciamento gênico. Após a transfecção, clones que incorporaram os plasmídeos foram selecionados através de seleção clonal usando o antibiótico puromicina. Esses experimentos foram realizados em colaboração com o aluno de mestrado Gustavo Carvalho Dias.

Como mostra a figura 10 , pode-se verificar que em linhagens isogênicas, a expressão de TFAM acompanha a expressão de p53. Os clones nos quais os níveis de p53 foram menores em relação à linhagem controle, os níveis de expressão de TFAM também foram menores, sugerindo que o controle de expressão das duas proteínas pode estar interligado. Porém, como essas vias de expressão são interconectadas e seu impacto na estabilidade do genoma mitocondrial ainda é desconhecido, logo necessita-se de mais estudos para compreender essas conexões. 
(A)

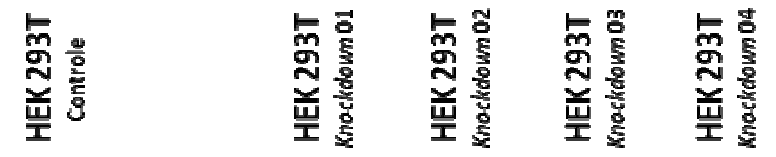
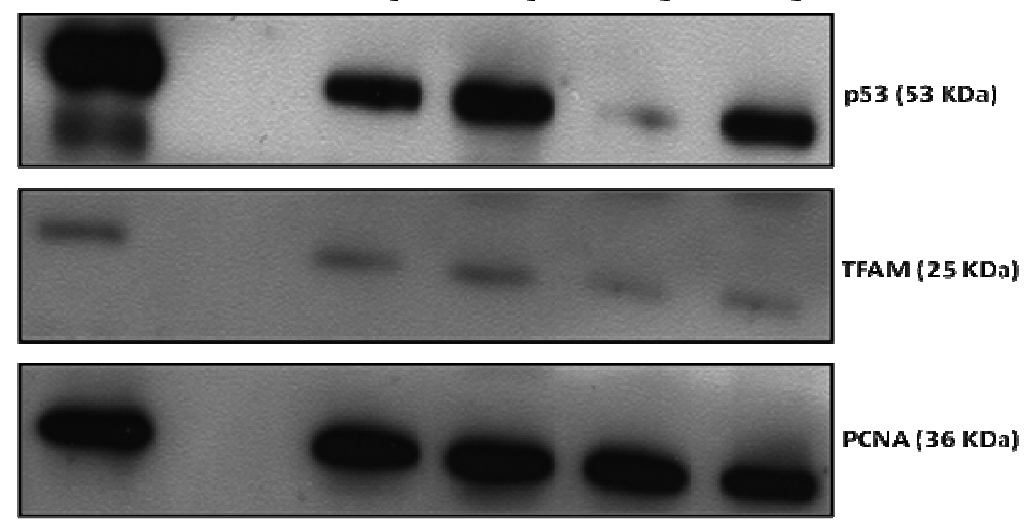

(B)

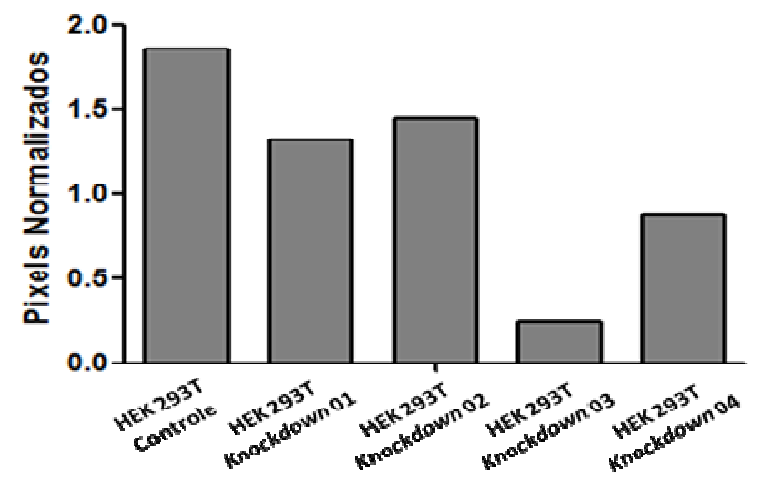

(C)

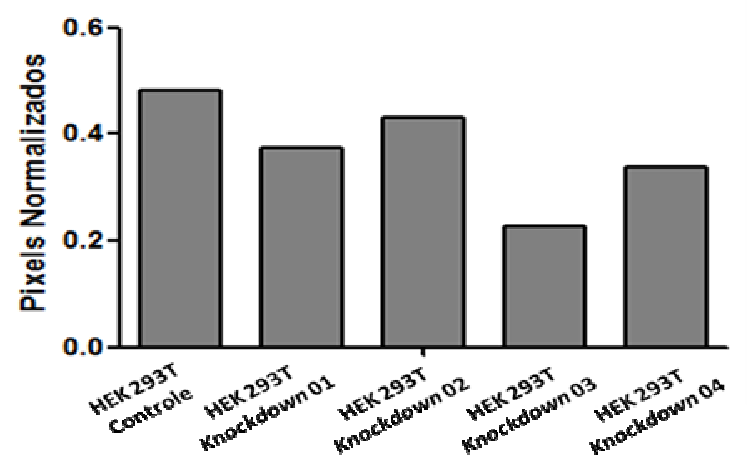

Figura 10 - Análise da expressão de p53 e TFAM em extratos celulares knockdown.

A expressão de p53 e TFAM foi avaliada por western blotting com anticorpos anti-p53 e anti-TFAM em extratos totais obtidos das linhagens celulares HEK293T transfectadas utilizando plasmídeos codificando shRNAs para o gene alvo TP53. Para esses ensaios, 20 ug de proteína total foram utilizadas. A imunodeteç̧ão com o anticorpo anti-PCNA mostrou que quantidades similares de proteínas foram analisadas nas diferentes amostras (A). Após imunodetecção, as bandas referentes a p53, TFAM e PCNA foram quantificadas pelo programa Image ${ }^{T M}$ e construído um histograma com a razão entre os valores de área relativos a p53 e PCNA (B), como também outro histograma com a razão entre os valores de área relativos a TFAM e PCNA (C). Fonte: autor da tese. 


\subsection{ANÁLISE DA EXPRESSÃO DE POL $\gamma$ EM CÉLULAS KNOCKDOWN PARA p53}

Como as diferentes linhagens celulares utilizadas nesse estudo não são isogênicas, é possível que a diferença na expressão de pol $\gamma$ resulte de outras alterações no controle da expressão gênica, independentes do estado de p53 da linhagem. Desta forma, para testar se o status de p53 influi diretamente na expressão de pol $\gamma$, testamos os níveis desta proteína em células HEK293T nas quais os níveis de p53 foram alterados pela expressão constitutiva de um RNA de interferência, como descrito no item anterior.

De acordo com a figura 11, verificou-se que em linhagens isogênicas, a expressão de pol $\gamma$ acompanha a expressão de p53. Os clones nos quais os níveis de p53 são menores em relação à linhagem controle, os níveis de expressão de pol $\gamma$ também são menores, sugerindo que o controle de expressão das duas proteínas pode estar interligado. Porém, como essas vias de expressão são interconectadas e seu impacto na estabilidade do genoma mitocondrial ainda é desconhecido, logo necessita-se de mais estudos para compreender essas conexões. 
(A)
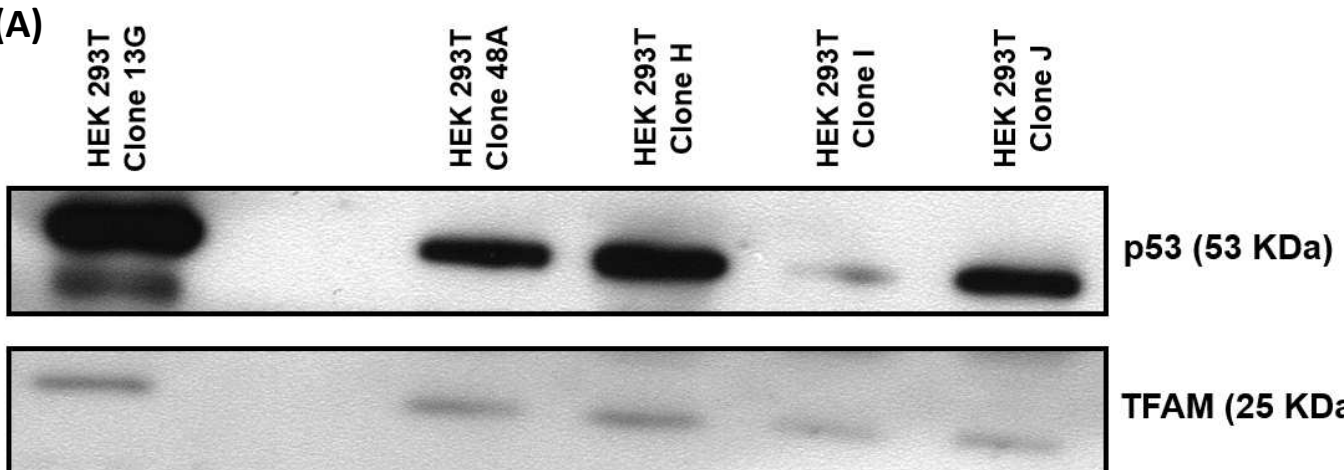

TFAM (25 KDa)

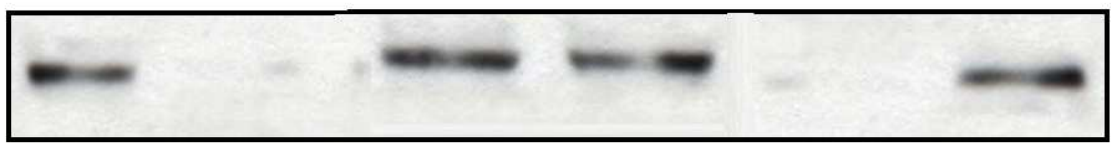

POLY (146 KDa)

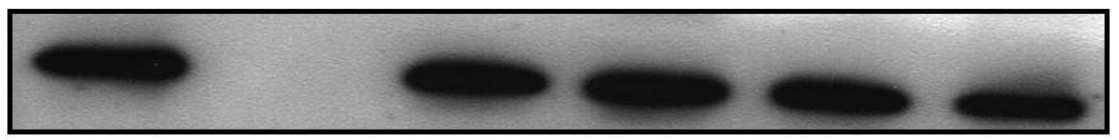

PCNA (36 KDa)

(B)

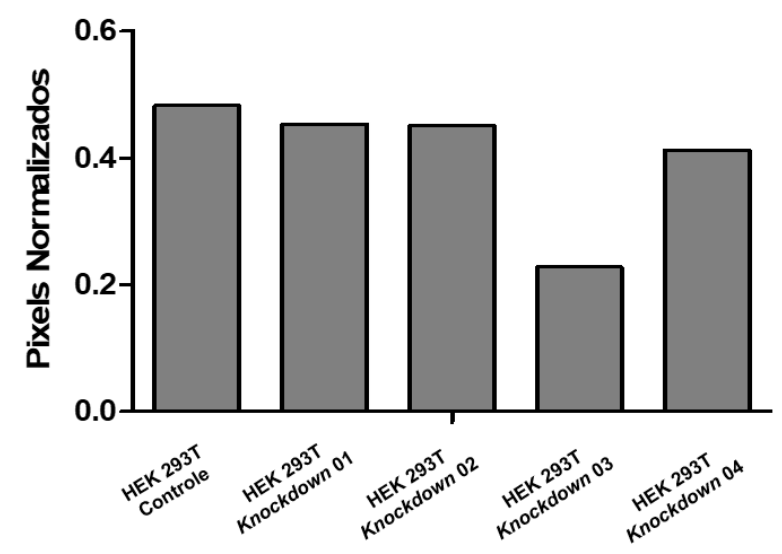

Figura 11 - Análise da expressão de p53, pol $\gamma$ e TFAM em extratos celulares knockdown para p53.

A expressão de p53, pol y e TFAM foi avaliada por western blotting com anticorpos anti-p53, anti-TFAM e anti-pol $\gamma$ em extratos totais obtidos das linhagens celulares HEK293T transfectadas utilizando plasmídeos codificando shRNAs para o gene alvo TP53. Para esses ensaios, 20 ug de proteína total foram utilizadas. A imunodetecção com o anticorpo anti-PCNA mostrou que quantidades similares de proteínas foram analisadas nas diferentes amostras (A). Após imunodetecção, as bandas referentes a pol $\gamma$ e PCNA foram quantificadas pelo programa ImageJ ${ }^{T M}$ e construído um histograma com a razão entre os valores de área relativos a pol y e PCNA (B). Fonte: autor da tese. 


\subsection{QUANTIFICAÇÃO DE TFAM EM CÉLULAS HEK293T TRANSFECTADAS COM ShRNAS PARA KNOCKDOWN DE TFAM}

Para gerarmos linhagens celulares com níveis de TFAM diminuídos, transfectouse células HEK293T com quatro construções contendo shRNAs com sequências distintas para TFAM. Após a seleção de células transfectadas com o antibiótico de seleção para o plasmídeo, a expressão de TFAM em cada linhagem foi verificada por western blotting do extrato total de proteínas dos transfectantes. Um western blotting mostrado na figura 12 e observou-se que os transfectantes $D$ e $F$ apresentaram uma redução significativa da expressão de TFAM, quando comparados com os controles negativos transfectados com um vetor vazio $(A)$ ou com uma sequência inespecífica (B). Esses experimentos foram realizados em colaboração com o aluno de mestrado Paulo Newton Tonolli.
(A)
(B)
(C)
(D)
(E)
(F)

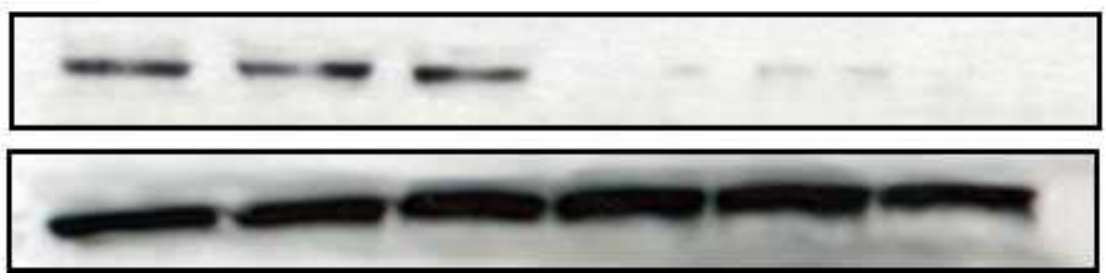

TFAM (25 KDa)

PCNA (36 KDa)

Figura 12 - Western blotting de extratos de proteínas dos clones de HEK293T transfectados para knockdown de TFAM.

(A) controle negativo (transfecção com plasmídeo sem sequência do shRNA); (B) controle negativo transfectado com sequência shRNA scrambled; (C), (D), (E), e (F) clones transfectados com plasmídeos contendo a sequência de shRNA. Fonte: autor da tese.

\subsection{QUANTIFICAÇÃO RELATIVA DO NÚMERO DE CÓPIAS DE mIDNA EM CLONES p53 KNOCKDOWN}

Centenas de mitocôndrias podem existir em um dado tipo celular, com cada organela possuindo entre 2 a 10 cópias do mtDNA. Uma vez que demonstrou-se que 
quando o status de p53 está dimuído, os status de TFAM e pol $\gamma$ também, intentou-se elucidar se as mesmas possuem função na manutenção do número de cópias e integridade do mtDNA. Para essa finalidade fez-se experimentos para determinar o número relativo de cópias de mtDNA, em células não transfectadas e transfectadas com shRNA para diminuir o nível de p53.

O número relativo de cópias de mtDNA foi determinado por meio de PCR quantitativo (qPCR), usando DNA total isolado das linhagens. Para a análise comparativa do número de cópias do mtDNA, os experimentos de qPCR utilizaram a amplificação de uma sequência do genoma mitocondrial de $250 \mathrm{pb}$, localizada no gene ND1, bem como uma sequência localizada no gene nuclear de cópia única HPRT, o qual foi usado como normalizador para a quantidade total de DNA utilizada como molde.

Dessa forma, é possível obter uma quantificação relativa de mtDNA em relação ao DNA nuclear. Na figura 13 observou-se que a diminuição do nível proteico de p53 resultou na redução significativa do número de cópias do mtDNA, quando comparado ao controle não transfectado. Esses experimentos foram realizados em colaboração com o aluno de mestrado Gustavo Carvalho Dias.

Os resultados apresentados na figura 13 indicaram que a diminuição dos níveis proteicos de p53 resulta na redução significativa do número de cópias de mtDNA por célula, sugerindo que p53 desempenha um papel importante na estabilidade genética mitocondrial. 


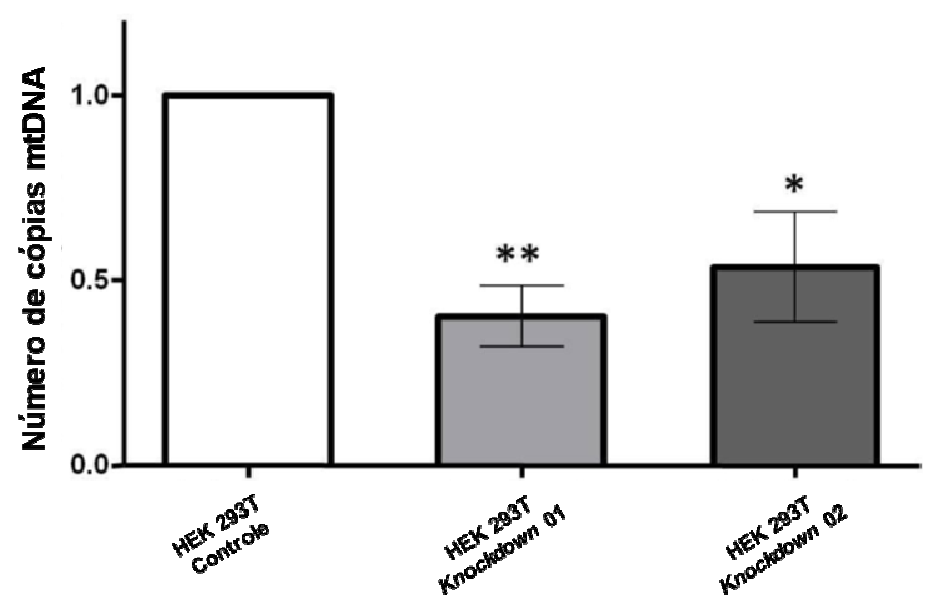

Figura 13 - Número de cópias de mtDNA em células HEK293T knockdown de p53.

Para cada linhagem, o conteúdo relativo de mtDNA foi obtido por meio da razão entre a amplificação de um gene mitocondrial ND1 e um gene nuclear de cópia única HPRT1. A razão obtida para o clone controle foi considerada 1 e os clones p53 KD foram normalizados contra este valor. Os resultados apresentados representaram a média \pm desvio padrão $(*) p<0,05$ e $\left(^{* *}\right) p<0,01$ comparados com o controle. Fonte: autor da tese.

\subsection{QUANTIFICAÇÃO RELATIVA DO NÚMERO DE CÓPIAS DE mtDNA EM CLONES}

\section{TFAM KNOCKDOWN}

Confirmou-se pela técnica de real time qPCR (qPCR) que as células HEK293T TFAM KD apresentaram uma redução significativa, de aproximadamente $40 \%$ no número de cópias de mtDNA comparado à linhagem controle (figura 14). Essa redução é explicada pelo fato de TFAM estar envolvido na replicação do mtDNA, implicando isso diretamente no número de cópias de mtDNA. Dessa forma, comprovou-se por outro método, que se gerou linhagens com expressão reduzida de TFAM. Esses experimentos foram realizados em colaboração com o aluno de mestrado Paulo Newton Tonolli. 


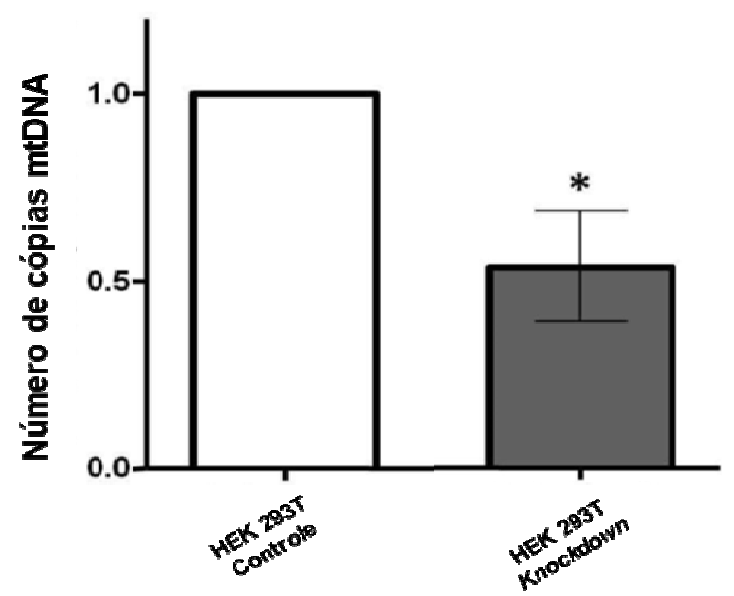

Figura 14 - Número de cópias de mtDNA em células HEK293T knockdown de TFAM.

Para cada linhagem, o conteúdo relativo de mtDNA foi obtido por meio da razão entre a amplificação de um gene mitocondrial ND1 e um gene nuclear de cópia única HPRT1. A razão obtida para o clone controle foi considerada 1 e os clones TFAM KD foram normalizados contra este valor. Os resultados apresentados representaram a média \pm desvio padrão $\left({ }^{*}\right) p<0,05$ comparados com o controle. Fonte: autor da tese.

\subsection{CO-IMUNOPRECIPITAÇÃO NAS FRAÇÕES MITOCONDRIAIS}

Como demonstrado nos resultados anteriores, pôde-se perceber que existe uma relação direta de p53 com pol ү e TFAM, já que seus status de expressão seguem um mesmo direcionamento e estão diretamente ligados na manutenção do mtDNA. Sendo assim, investigou-se se p53 interage física e diretamente com pol $\gamma$, ou se existe uma relação com TFAM, que mediaria a interação funcional entre essas duas proteínas durante os mecanismos de reparo.

Para isso foram feitos experimentos de co-imunoprecipitação de proteínas. Nesses experimentos pol $\gamma$ foi usada como "isca". Para a imunodetecção dos complexos imunoprecipitados, usou-se anticorpo contra p53 e TFAM. Como pode ser visto na figura 15, na faixa de migração correspondente a massa molar da pol $\gamma$ (146 $\mathrm{KDa}$ ), essa proteína foi imunodectada na fração mitocondrial das linhagens celulares HEK293T controle e TFAM KD, bem como no input, que é um controle de loading, representado pelo extrato celular total. Porém, a imunodetecção de TFAM e p53 só se deram na linhagem controle e no input. Isso corrobora com a idéia de que na ausência de TFAM, p53 não interage fisicamente com pol $y$ para estabelecer a maquinaria de reparo. Diante disso, esses resultados sugeriram a existência de uma relação física e 
funcional entre p53, TFAM e pol $\gamma$ na replicação e manutenção do mtDNA, uma vez que pol $\gamma$ e p53 imunoprecipitam somente na presença de TFAM.

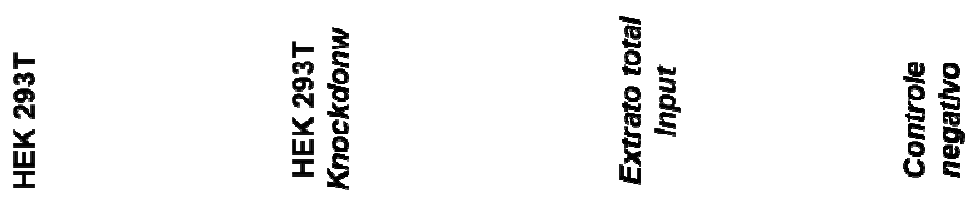

POLY (146 KDa)
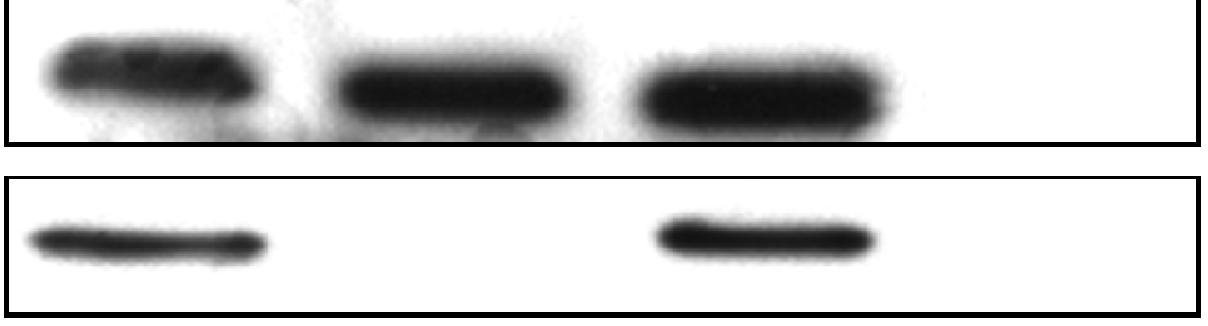

p53 (53 KDa)

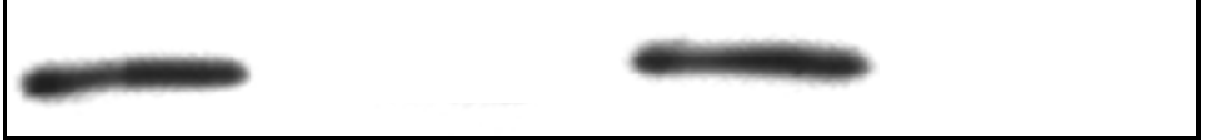

TFAM (25 KDa)

Figura 15 - Análise da co-imunoprecipitação de p53, TFAM e pol y nas frações mitocondriais em extratos celulares knockdown para TFAM.

O imunoprecipitado obtido usando o anticorpo contra pol $\gamma$ (painel superior) foi analisado por western blotting usando anticorpo contra TFAM (painel inferior) e anticorpo anti-p53 (painel do meio), para confirmar a imunoprecipitação dessas proteínas. $O$ controle negativo foi um controle de anticorpo não reativo. Fonte: autor da tese.

\subsection{ENSAIO DE LESÃO DE mtDNA APÓS ESTRESSE OXIDATIVO}

Após a indução de estresse oxidativo, mediante radiação ionizante (radiação gama), foi observado um número significativo de lesões na linhagem TFAM KD comparado ao controle (figura 16), indicando que TFAM apresentou um importante papel na proteção do mtDNA contra lesões oxidadas durante o estresse oxidativo.

Isso indica que o efeito de diminuição da amplificação relativa de mtDNA:ND1 na linhagem TFAM KD foi suposto ser devido a geração secundária de EROs na mitocôndria, como por meio da peroxidação lipídica. O mtDNA se encontra muito próximo da membrana mitocondrial interna, acarretando na oxidação de seus lipídios, o que resultou possivelmente em um cenário de crescente lesão ao mtDNA. Porém 
esses dados também indicaram que em células knockdown para TFAM, o mtDNA também se apresentou mais danificado, uma vez que não houve interação entre pol $\gamma$ e p53, necessários para acionar a maquinaria de reparo. Esses experimentos foram realizados em colaboração com o aluno de mestrado Paulo Newton Tonolli.

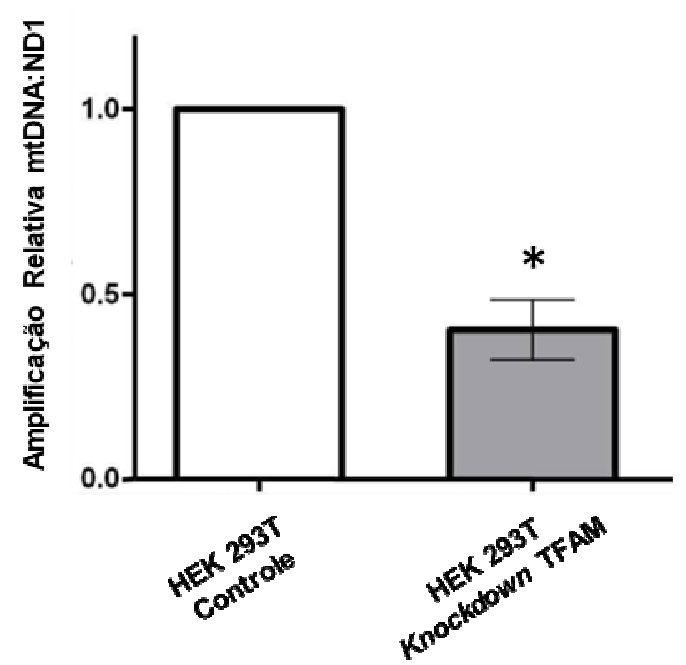

Figura 16 - Quantificação relativa de lesões oxidadas no mtDNA.

A quantificação relativa de lesões oxidadas no mtDNA foi realizada por meio da indução de estresse oxidativo por radiação ionizante (5 Gy de radiação gama utilizando um irradiador Gammacell 220). Média dos valores relativos de pixels de bandas de XL-PCR:ND1, utilizando a linhagem controle como referência $* p<0,05$. Fonte: autor da tese. 


\section{DISCUSSÃO}

A homeostase celular depende da integridade funcional e da coordenação entre os diversos sub-sistemas que coexistem intracelularmente. Esses, muitas vezes estão separados espacialmente, embora em um pequeno espaço de apenas alguns micrômetros. Nesse espaço, cada sub-sistema desempenha papéis distintos, mas complementares, no qual o produto formado em um é sempre usado em outras reações, o que culmina em uma rede necessária para todo o funcionamento da maquinaria celular, o metabolismo.

Uma integrante dessa rede intracelular são as mitocôndrias, organelas nas quais ocorre a oxidação de biomoléculas e a produção de ATP, que é necessário para diversos eventos celulares. Além dessa função, essas organelas também estão envolvidas em eventos de sinalização e em diferentes tipos de morte celular (GALLUZZI et al., 2012). Para que haja o funcionamento mitocondrial e aporte energético celular, é necessária a expressão coordenada dos dois genomas, mitocondrial e nuclear, a fim de sintetizar todos os componentes estruturais e funcionais dessa organela.

Essa coordenação envolve a síntese de todas as subunidades dos complexos que compõem a cadeia de transporte de elétrons, o transporte das mesmas até a mitocôndria, além da montagem adequada desses complexos com a combinação das subunidades codificadas por ambos genomas (SCARPULLA, VEJA, KELLY, 2012). Sendo assim, a manutenção da integridade do genoma mitocondrial é também essencial para sua integridade funcional, uma vez que mutações nesse genoma, tanto nos genes que codificam diretamente as subunidades dos complexos respiratórios, como mutações nos genes envolvidos na síntese proteica (tRNA ou rRNA), podem resultar em deficiência na produção de proteínas intramitocondriais, comprometimento ou perda da atividade dos complexos respiratórios, além de aumento da produção mitocondrial de EROs, levando a um desbalanço redox (LAGOUGE, LARSSON, 2013; WALLACE, 2010).

As disfunções mitocondriais estão envolvidas em várias patologias humanas como câncer, diabetes, neurodegeneração e também no envelhecimento normal. Em muitas dessas patologias, disfunção e comprometimento mitocondrial estão associadas à ineficiência na produção energética bem como no aumento da geração de EROs decorrentes de mutações no mtDNA. Em humanos mais de 150 mutações patogênicas já 
foram identificadas no mtDNA e a prevalência dessas mutações na população é estimada em aproximadamente 1 a cada 5.000 nascidos. Dessa forma, fica evidente o impacto na saúde pública causado pelas disfunções mitocondriais (WALLACE, 2010; YANG et al., 2008).

O mtDNA está associado com a membrana mitocondrial interna e muito próximo a cadeia de transporte de elétrons e aos sítios de geração de EROs, o que faz com que esse seja um alvo primário do ataque dessas espécies, resultando no acúmulo preferencial de bases oxidadas, quando comparado ao DNA nuclear (LAGOUGE e LARSSON, 2013). De fato, a vulnerabilidade do mtDNA a modificações oxidadas nas suas bases pode ser ilustrada pelo fato de 8-oxo-dG acumular mais no mtDNA do que no DNA nuclear (BACMAN et al., 2009). E BER é a maior via de reparo de mtDNA para pequenas alterações de bases como danos oxidativos e alquilações (OFFER, 1999)

O acúmulo de mutações no mtDNA pode afetar a estrutura e a expressão das proteínas da cadeia respiratória, que não funcionando adequadamente, podem levar ao aumento da produção de EROs (FISHEL et al., 2003). Nessa condição, se estabelece um círculo vicioso que resulta em mais danos ao mtDNA e a redução na produção de ATP. De fato, evidências sugerem que danos agudos sobre o mtDNA, e um desequilíbrio no seu reparo, podem estar relacionados a sua degradação e a apoptose (RUCHKO et al., 2005).

Durante muito tempo se pensou que o mtDNA estivesse nu, ficando exposto livremente a agentes genotóxicos, diferentemente do DNA nuclear, que está empacotado por histonas (KANG e HAMASAKI, 2002), o que poderia explicar, em parte, o maior acúmulo de lesões no mtDNA. A identificação de TFAM como a principal proteína componente do nucleóide mitocondrial modificou esse paradigma. Revestindo todo o mtDNA, TFAM poderia funcionar como uma barreira física para o acesso de espécies reativas ao mtDNA, protegendo-o do ataque por EROs.

Apesar de alguns estudos recentes, pouco se sabe sobre o papel de TFAM na proteção do mtDNA em condições de estresse oxidativo (HAYASHI et al., 2008; XU et al., 2009; MORIMOTO et al., 2012). Um estudo com camundongos transgênicos que superexpressavam TFAM relatou uma redução da geração de EROs, devido ao aumento 
no número de cópias de mtDNA e melhoria na função respiratória mitocondrial (IKEUCHI et al., 2005).

Apesar de esses estudos sugerirem que TFAM protege o mtDNA de lesões oxidadas, nenhum deles mediu o nível de lesões no mtDNA após o estresse oxidativo, e tampouco a capacidade de reparo do mtDNA. Nesse contexto, nosso trabalho obteve algumas respostas dos possíveis papéis de TFAM na proteção do mtDNA e como ele pode atuar no reparo dessa molécula.

Nesse sentido, p53 também desempenha um papel fundamental na proteção ao mtDNA contra lesões oxidadas. OFFER (1999) demonstrou que um aumento da expressão de p53 induziu a síntese de reparo em sítios abásicos independente da atividade transcricional de $\mathrm{p} 53$, porque um mutante deficiente nesta atividade foi mais eficiente em estimular BER do que $p 53$ selvagem.

Outros estudos sugeriram o papel de p53 controlando também as funções mitocondriais em resposta ao estresse (MOLL, ZAIKA, 2001). Após vários estímulos de morte, uma fração da proteína p53 transloca para a mitocôndria, o que provoca uma série de respostas que podem levar a morte celular (MIHARA et al., 2003). Porém p53 pode translocar para a organela independente de apoptose, o que sugere o papel de p53 no interior da mitocôndria na maquinaria de reparo (ESSMANN et al., 2005).

Resultados recentes indicaram que esse papel pode estar relacionado com a manutenção da estabilidade do mtDNA, por meio de possíveis cooperações com vários fatores durante a síntese de DNA, como reportado por ACHANTA et al. (2005), DE SOUZA-PINTO et al. (2004), BAKHANASHIVILLI et al. (2008), WONG et al. (2009) e CANUGOVI et al. (2010). No entanto, como p53 participa de mtBER ainda não está claramente definido.

O grupo da profa Nadja Cristhina de Souza Pinto, foi um dos primeiros a investigar uma participação direta de p53 em mtBER. Em experimentos comparando as atividades de BER in vitro em extratos de mitocôndria de fígado obtidos de camundongos com p53 selvagem, em heterozigose $\left(\mathrm{p} 53^{-/+}\right)$e knockout $\left(\mathrm{p} 53^{-/-}\right)$ observaram uma diminuição significativa na atividade de incorporação de nucleotídeos nos extratos dos camundongos heterozigotos e knockouts para p53. Esta deficiência foi complementada pela adição de p53 recombinante, sugerindo, portanto, que p53 
modula mtBER (DE SOUZA-PINTO et al., 2004). Como mitocôndrias de mamíferos possuem apenas uma DNA polimerase descrita, a DNA polimerase $\gamma$, que participa tanto de replicação como de reparo, postularam que p53 interage funcionalmente com a DNA pol $\gamma$, modulando assim sua atividade durante BER (DE SOUZA-PINTO et al., 2004).

Além disso, em resultados obtidos em colaboração com o grupo do Dr. Vilhelm Bohr, do National Institute on Aging, USA, foi demonstrado que p53 pode modular a ligação de TFAM, um componente essencial do complexo nucleoproteico no qual se encontra o mtDNA (CANUGOVI et al., 2010). A ligação de TFAM ao DNA restringe o acesso de proteínas de reparo, como dito anteriormente, e nesse contexto p53 pode funcionar facilitando esse acesso pela remoção de TFAM dos sítios de lesões no DNA.

Nesse contexto, esse trabalho pode ser dividido em três blocos de resultados principais. Em primeiro lugar, as linhagens celulares que possuem níveis reduzidos do supressor de tumor p53, tem status de TFAM e pol $\gamma$ diminuidos e a depleção de mtDNA foi dependente dessas duas proteínas (figuras 9, 10, 11, 13 e 14), dois fatores que foram previamente vinculados à manutenção do número de cópias de mtDNA (SHADEL, 2008). Em segundo lugar, p53 interage funcionalmente com DNA pol $\gamma$, modulando assim sua atividade, porém essa interação funcional não é fisicamente direta, TFAM modula essa interação, já que em sua ausência, pol y e p53 não imunoprecipitam (figura 15). E em terceiro lugar, há um aumento significativo nos níveis de lesão do mtDNA, após estresse oxidativo, quando em células knockdown para TFAM, uma vez que não há interação entre pol y e p53, necessários para acionar a maquinaria de reparo (figura 16). 0 fato de que todas essas mudanças estão ocorrendo em células na ausência de dano induzido no DNA, implica que a depleção de mtDNA e as EROS mitocondriais perturbam a homeostase celular e são potenciais fatores que promovem fenótipos de células modificadas mediadas por p53.

O mecanismo de depleção de mtDNA que acompanha a perda de p53, tem algumas explicações plausíveis que não são mutuamente exclusivas. Em primeiro lugar, a expressão reduzida de p53 é provavelmente responsável em parte pela depleção de mtDNA. Esta proteína é um alvo transcricional direto na presença de dano ao DNA (TANAKA et al., 2000; NAKANO et al., 2000) e inativar seu gene causa depleção de mtDNA em humanos e camundongos (BOURDON et al. 2008). A expressão reduzida de 
p53 deverá levar a quantidades diminuídas de complexos R1-p53R2, a forma da enzima que tem sido implicada especificamente no fornecimento de dNTPs para replicação e reparo de mtDNA (LEBEDEVA et al., 2007; HAKANSSON et al., 2008) resultando na depleção de mtDNA.

Uma segunda possibilidade é que a down-regulation de TFAM, na ausência de p53, é que impulsiona a depleção de mtDNA. A perda de expressão de TFAM é relatada como causadora de depleção de mtDNA (CANUGOVI et al., 2010), mas seus níveis de proteína também refletem passivamente os de mtDNA quando o mtDNA é esgotado pelo tratamento com brometo de etidio ou inibidores de pol y (SEIDEL-ROGOL et al., 2010). Pode-se inferir que a redução no nível de TFAM nas células empobrecidas em p53 é provavelmente devido à sua degradação em resposta a níveis reduzidos de mtDNA (isto é, é instável quando não vinculado ao mtDNA) ou alguma outra forma de regulação pós-transcricional. Essa instabilidade pode ser impulsionada pela perda de sua interação física proposta com p53 nas mitocôndrias.

Dado que p53 está fisicamente localizado nas mitocôndrias, também é possível que sua perda na organela per se seja a causa da depleção de mtDNA observada. Isso pode ser devido à perda das interações propostas com TFAM e pol $\gamma$ necessárias para a eficiência da replicação ou reparo mtDNA. Também é possível que p53 funcione como um fator de transcrição nas mitocôndrias (HEYNE et al., 2008) e, portanto, sua ausência leva à capacidade reduzida na replicação do mtDNA. No entanto, esta última possibilidade parece ser menos provável, dado os recentes estudos de que p53, na mitocôndria, parece atuar como um monômero, que não é o seu modo típico na transcrição (HEYNE et al., 2008). Descifrar quais desses caminhos são os principais responsáveis pela depleção de mtDNA na ausência de p53 é uma área intrigante para futuras investigações.

Corroborando com esses dados, os resultados do experimento de XL-PCR mostraram que as células knockdown TFAM apresentaram um maior número de lesões oxidadas após o tratamento com radiação ionizante, resultando em uma diminuição dos produtos de amplificação devido ao bloqueio da DNA polimerase. Isso sugeriu que TFAM, de fato, exerceu um papel protetor ao mtDNA, reduzindo a ocorrência das lesões 
oxidadas. Sugeriu-se que isso é possível devido a formação de uma barreira física ao acesso das EROs às bases e ao esqueleto de açúcar-fosfato do mtDNA.

Porém, mesmo sabendo que TFAM está ligado em quase toda a extensão do mtDNA, sua ligação ao mtDNA não impede completamente a formação de lesões oxidadas após o estresse oxidativo, em que foi observada a formação de lesões bloqueadoras mesmo em células controle, expressando níveis normais de TFAM (TONOLLI, 2013). De fato, já foi demonstrado que, in vitro, TFAM se liga com maior afinidade ao DNA contendo 8-oxodG (YOSHIDA et al., 2002; CANUGOVI et al., 2010); e que, também in vitro, a ligação de TFAM ao substrato tem a capacidade de inibir competitivamente o acesso das enzimas de reparo (CANUGOVI et al., 2010).

A radiação ionizante foi utilizada como modelo para estresse oxidativo nesse trabalho pois promovem a instauração do estresse mediante alguns mecanismos como: a ativação das NADPH oxidases, a disfunção da cadeia transportadora de elétrons mitocondrial e a redução da atividade das enzimas antioxidantes, sobretudo da SODMn. LEMON et al. (2008) demonstraram maiores níveis de 8-Hidroxyl-2'-Deoxyguanosine (8-OHdG), marcador de dano oxidativo ao DNA, em ratos submetidos à radiação gama proveniente de uma fonte radiotiva de césio $\left({ }^{137} \mathrm{Cs}\right)$. Outros estudos ratificam o efeito das radiações ionizantes sobre marcadores do estresse oxidativo, sobretudo os referentes ao dano oxidativo ao mtDNA (KIM et al., 2006), decorrentes dos processos mutagênicos e instabilidade genômica.

A modulação da ligação de TFAM ao mtDNA é sugerida como um possível mecanismo de regulação do acesso das enzimas de reparo às lesões oxidadas (CANUGOVI et al. 2010; YOSHIDA et al., 2002). Experimentos comprovaram a interação física entre a proteína supressora de tumor p53 e TFAM, durante a apoptose, quando p53 é translocada para a mitocôndria (WONG et al., 2009). Essa interação pode mediar a ligação de TFAM ao mtDNA, inclusive às modificações oxidadas, conforme foi observado em experimentos in vitro (YOSHIDA et al., 2002). YOSHIDA et al. (2002) demonstraram que a ligação de p53 a TFAM aumentava em 10 a 20 vezes a atividade de ligação de TFAM ao mtDNA, enquanto inibia a ligação de TFAM ao mtDNA oxidado (8-oxo-dG). No entanto, mais estudos são necessários para investigar de que forma essa interação 
ocorre in vivo, e de que forma ela atua durante o estresse oxidativo e no reparo do mtDNA.

Sabe-se que p53 pode modular a atividade de reparo do mtDNA, provavelmente via uma interação funcional com DNA polimerase $\gamma$ (a única DNA polimerase mitocondrial) (SOUZA-PINTO et al., 2004). Desse modo, p53 poderia funcionar como um modulador da atividade de reparo de mtDNA via sua interação com TFAM, e também via o estimulo da atividade de pol $\gamma$. Também é possível que outras proteínas podem estar envolvidas na resposta celular às lesões oxidadas durante o estresse oxidativo por meio de interações com TFAM e da modulação de sua ligação ao mtDNA. Recentemente, foi relatado que a proteína CSB (Cockaynesyndromegroup B), envolvida em diversos processos como o reparo por excisão de nucleotídeos (NER) e reparo por excisão de base (BER), é capaz de modular a ligação de TFAM ao mtDNA (BERQUIST et al., 2012). Dessa forma, CSB, tal como p53, poderia facilitar o reparo do mtDNA, deslocando TFAM dos sítios de lesões, permitindo um reconhecimento e a remoção eficiente dessas.

Além das interações entre as proteínas e das modulações da atividade de reparo e ligação de TFAM ao mtDNA, a ocorrência de modificações pós-traducionais em TFAM pode ser também uma via de regulação para o reparo do mtDNA durante o estresse oxidativo. Algumas modificações covalentes em TFAM já foram relatadas, como a acetilação (DINARDO et al., 2003), a fosforilação (LU et al., 2013), e a ubiquitinação (ANTELMAN et al., 2008). Apesar desses estudos, não existe ainda nenhuma investigação sobre como as possíveis modificações pós-traducionais em TFAM estão relacionadas ao processo de reparo do mtDNA. As modificações pós-traducionais em proteínas ligantes ao DNA são importantes mecanismos regulatórios da replicação, expressão gênica, e reparo de DNA (HASAN et al., 2002; LI et al., 2007). É possível que modificações pós-traducionais em TFAM regulem a sua interação com o DNA, modulando, assim, o acesso das proteínas de reparo ao mtDNA. De forma análoga, proteínas que compactam o DNA nuclear, as histonas, sofrem constantes modificações covalentes para a remodelagem da cromatina durante processos metabólicos como a expressão gênica e o reparo de DNA.

Em suma, os resultados deste trabalho sugerem, juntamente com algumas evidências já existentes, que há uma interação entre p53 e TFAM com impacto em pol $\gamma$. 
A proteína p53 pode modular a ligação de TFAM ao DNA, que por sua vez podem restringir o acesso de proteínas de reparo $B E R$, e também sugere que mitocôndrias humanas possuem as vias canônicas para o reparo de lesões oxidativas, e que essas são mecanisticamente conservadas no núcleo e mitocôndria além de compartilharem a maioria dos seus componentes. Para isso, elucidou-se um possível mecanismo da ação dessas três proteínas em conjunto, durante o mtBER, como mostrado na figura 17. 


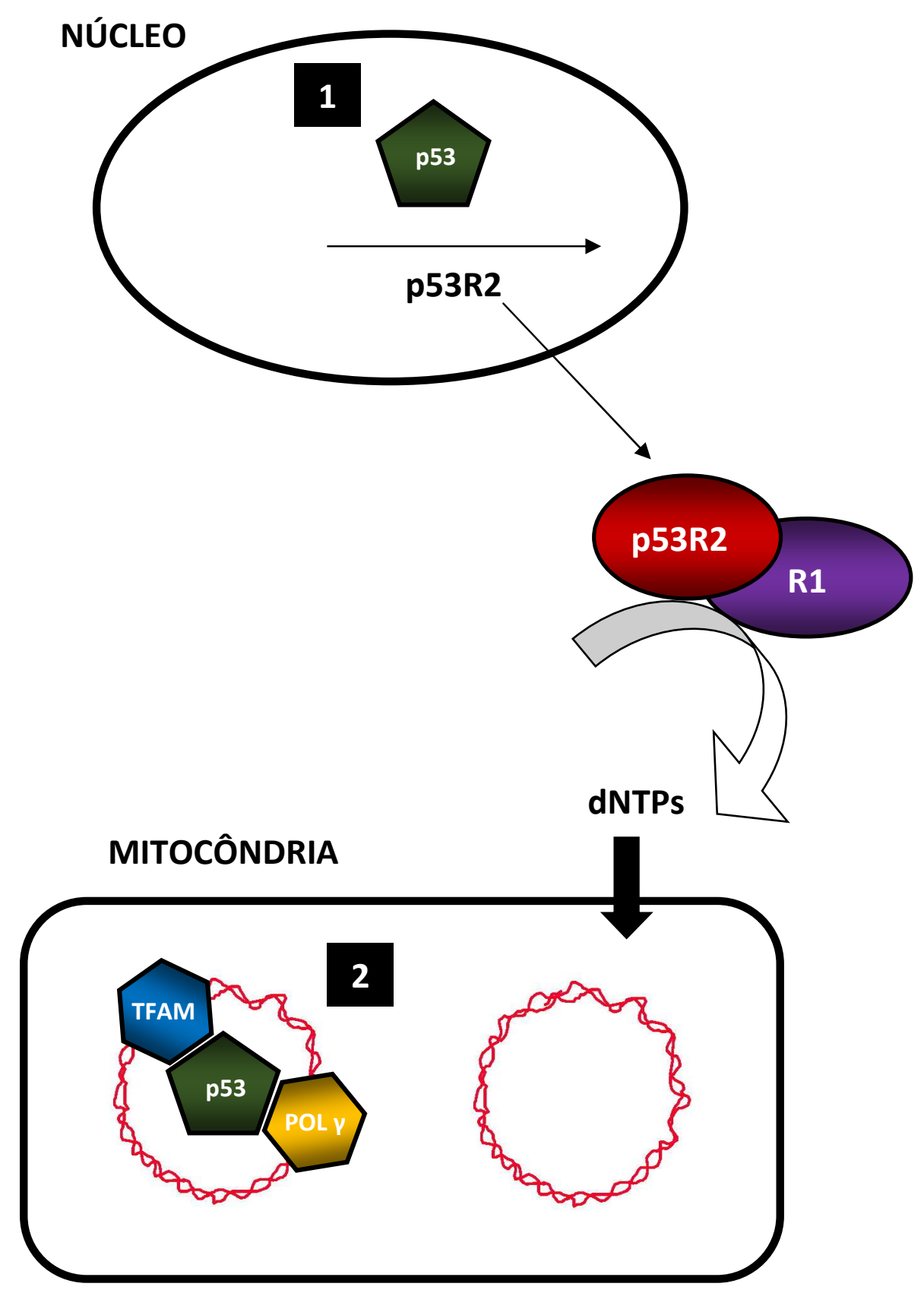

Figura 17 - Representação esquemática das potenciais funções nucleares e mitocondriais de p53 na manutenção do número de cópias de mtDNA.

No topo da figura, p53 nuclear é mostrada como produto da ativação do seu gene alvo, mesmo na ausência de danos no DNA. Na parte inferior da figura, p53 mitocondrial é mostrada associada ao mtDNA (círculo irregular) e seus supostos parceiros de ligação, TFAM e pol $\gamma$, cada um deles requerido para replicação e manutenção do mtDNA. A perda de p53 causa depleção de mtDNA por um ou mais mecanismos, que envolvem (1) sua função nuclear como fator de transcrição, ou (2) suas funções mitocondriais. A falta de p53 no núcleo resulta em uma expressão reduzida de p53R2, e diminuição na produção de dNTPs pela forma p53R2-R1 (ovais no centro à direita), o que compromete a replicação ou 
reparo de mtDNA, causando sua depleção. Os níveis reduzidos de mtDNA podem levar a níveis reduzidos da proteína TFAM e sua ligação ao DNA, necessária para a sua estabilidade. A falta de p53 na mitocôndria pode causar a depleção do mtDNA, pois p53 se liga e estabiliza TFAM ou é necessário para uma atividade ótima de pol $y$ na replicação ou reparo de mtDNA. Fonte: autor da tese.

A identificação e caracterização parcial dessas vias em mitocôndrias desenvolvidas nesse trabalho, no entanto, coloca muitas outras questões que devem agora ser abordadas, como: i) como essas vias são reguladas e relacionam-se com outras vias de reparo distintas presentes nas mitocôndrias; ii) quais são os sinais necessários para que essas proteínas sejam direcionadas à essa organela e atuem na manutenção da integridade mitocondrial, e da célula como um todo; e iii) qual a participação dessa via na manutenção da integridade funcional da mitocôndria sobre condições normais e em reposta a diferentes estresses genotóxicos e metabólicos. 
CONCLUSOEES 


\section{CONCLUSÕES}

Neste estudo, expandiu-se a compreensão de como p53 afeta a homeostase mitocondrial, já que é necessária para manter o número normal de cópias de mtDNA e a homeostase mitocondrial e celular. Essas funções recém-atribuídas para p53 provavelmente estão envolvidas na importante função dessa proteína na vigilância celular e como a perda de suas funções pode promove alterações no metabolismo e na tumorigênese.

Para essa manutenção mitocondrial, por este trabalho, pode-se indicar que: i) p53 e pol y não interagem física e diretamente, existe uma proteína acopladora, TFAM, que realiza a manutenção da maquinaria de reparo nessa organela; ii) a interação entre p53 e o fator de transcrição/replicação mitocondrial (TFAM) modula o papel de p53 na manutenção da integridade do genoma mitocondrial e iii) a ausência de TFAM na mitocôndria, em resposta a agentes que causam danos no mtDNA, aumentam o número de lesões nessa molécula, uma vez que o complexo TFAM/p53/pol $\gamma$ não é formado durante o mecanismo de reparo. 
REFERENCIAS BIBLIOGRAFICAS 


\section{REFERÊNCIAS BIBLIOGRÁFICAS}

ACHANTA, G.; SASAKI, R.; FENG, L.; CAREW, J. S.; LU, W.; PELICANO, H.; KEATING, M. J. HUANG, P. Novel role of p53 in maintaining mitochondrial genetic stability through interaction with DNA Pol gamma. The EMBO Journal. v. 24, n. 19, p. 3482-92, 2005.

ACHSEL, T.; AHRENS, K.; BRAHMS, H.; TEIGELKAMP, S.; LÜHRMANN, R. The human U5$220 \mathrm{kD}$ protein (hPrp8) forms a stable RNA-free complex with several U5-specific proteins, including an RNA unwindase, a homologue of ribosomal elongation factor EF2, and a novel WD-40 protein. Molecular and Cellular Biology. v. 18, n. 11, p. 6756-66, 1998.

AKBARI, M.; OTTERLEI, M.; PEÑA-DIAZ, J.; KROKAN, H. E. Different organization of base excision repair of uracil in DNA in nuclei and mitochondria and selective upregulation of mitochondrial uracil-DNA glycosylase after oxidative stress. Neuroscience. v. 145, n. 4, p. 1201-1212, 2007.

ALBRECHTSEN, N.; DORNREITER, I.; GROSSE, F.; KIM, E.; WIESMÜLLER, L.; DEPPERT, W. Maintenance of genomic integrity by $\mathrm{p} 53$ : complementary roles for activated and nonactivated p53. Oncogene. v. 18, n. 53, p. 7706-17, 1999.

ANDERSON, C. T.; FRIEDBERG, E. C. The presence of nuclear and mitochondrial uracil DNA glycosylase in extracts of human KB cells. Nucleic Acids Research. v. 8, n. 4, p. 875-888, 1980.

ANDERSON, S.; BANKIER, A. T.; BARRELL, B. G.; DE BRUIJN, M. H.; COULSON, A. R.; DROUIN, J.; EPERON, I. C.; NIERLICH, D. P.; ROE, B. A.; SANGER, F.; SCHREIER, P. H.; SMITH, A. J.; STADEN, R.; YOUNG, I. G. Sequence and organization of the human mitochondrial genome. Nature. v. 290, n. 5806, p. 457-65, 1981.

ANTELMAN, J.; MANANDHAR, G.; YI, Y. J.; WHITWORTH, K. M.; SUTOVSKY, M.; AGCA, C.; PRATHER, R. S.; SUTOVSKY, P. Expression of mitochondrial transcription factor $A$ (TFAM) during porcine gametogenesis and preimplantation embryo development. Journal of Cellular Physiology. v. 217, n. 2, p. 529-43, 2008.

BACMAN, S. R.; WILLIAMS, S. L.; MORAES, C. T. Intra- and inter-molecular recombination of mitochondrial DNA after in vivo induction of multiple double-strand breaks. Nucleic Acids Research. v. 37, p. 4218-4226, 2009. 
BAKER, S. J.; KINZLER, K. W.; VOGELSTEIN, B. Knudson's hypothesis and the TP53 revolution. Genes Chromosomes Cancer. v. 38, n. 4, p. 329, 2003.

BAKHANASHVILI, M.; GRINBERG, S.; BONDA, E.; SIMON, A. J.; MOSHITCHMOSHKOVITZ, S.; RAHAV, G. p53 in mitochondria enhances the accuracy of DNA synthesis. Cell Death and Differentiation. v. 15, n. 12, p. 1865-74, 2008.

BELL, O. Determinants and dynamics of genome accessibility. Nature Reviews Genetics. v. 12, p. 554-564, 2011.

BERgEAUd, M. L.; MATHIEU, A.; GUILLAUME, U. M.; MOLL, B.; MIGNOTTE, N.; LE FLOCH, J. L.; VAYSSIERE, E. V. Mitochondrial p53 mediates a transcription-independent regulation of cell respiration and interacts with the mitochondrial $F(1) F(0)$-ATP synthase. Cell Cycle. n. 12, p. 2781-2793, 2013.

BERQUIST, B.; CANUGOVI, C.; SYKORA, P.; WILSON III, D.; BOHR, V. A. Human Cockayne syndrome $B$ protein reciprocally communicates with mitochondrial proteins and promotes transcriptional elongation. Nucleic Acids Research. v. 40, n. 17, p. 83928405, 2012.

BOHR, V. A. DNA damage and its processing. relation to human disease. Journal of Inherited Metabolic Disease. v. 25, p. 215-222, 2002.

BOHR, V. A.; STEVNSNER, T.; DE SOUZA-PINTO, N. C. Mitochondrial DNA repair of oxidative damage in mammalian cells. Gene. v. 286, n. 1, p. 127-34, 2002.

BONAWITZ, N. D.; CLAYTON, D. A.; SHADEL, G. S. Initiation and beyond: multiple functions of the human mitochondrial transcription machinery. Molecular Cell Biology. v. 24, p. 813-825, 2006.

BOTA, D. A.; DAVIES, K. J. Protein degradation in mitochondria implication for oxidative stress, aging and disease: a novel etiological classification of mitochondrial proteolytic disorders. Mitochondrion. v. 1, n. 1, p. 33-49, 2001.

BOURDON, A.; MINAI, L.; SERRE, V.; JAIS, J. P.; SARZI, E.; AUBERT, S.; CHRETIEN, D.; DE LONLAY, P.; PAQUIS-FLUCKLINGER, V.; ARAKAWA, H.; NAKAMURA, Y.; MUNNICH, A.; ROTIG, A. Mutation of RRM2B, encoding p53-controlled ribonucleotide reductase 
(p53R2), causes severe mitochondrial DNA depletion. Nature Genetics. n. 39, p. 776780, 2007.

BRANDON, M.; BALDI, P.; WALLACE, D. C. Mitochondrial mutations in cancer. Oncogene. v. 25, n. 34, p. 4647-4662, 2006.

BROWN, W. M.; GEORGE, M.; WILSON, A. C. Rapid evolution of animal mitochondrial DNA. Proceedings of the National Academy of Sciences of the United States of America. v. 76, n. 4, p. 1967-1971, 1979.

CADET, J.; RICHARD WAGNER, J. DNA base damage by reactive oxygen species, oxidizing agents, and UV radiation. Cold Spring Harbor Perspectives in Biology. v. 5, 2013.

CANUGOVI, C.; MAYNARD, S.; BAYNE, A.C.; SYKORA, P.; TIAN, J.; DE SOUZA-PINTO, N. C.; CROTEAU, D. L.; BOHR, V. A. The mitochondrial transcription factor A functions in mitochondrial base excision repair. DNA Repair (Amst). v. 9, n. 10, p. 1080-9, 2010.

CHEN, D.; YU, Z.; ZHU, Z.; LOPEZ, C.D. The p53 pathway promotes efficient mitochondrial DNA base excision repair in colorectal cancer cells. Cancer Research. v. 66, n. 7, p. 3485-94, 2006.

CHEN, F.; WANG, W.; EL-DEIRY, W.S. Current strategies to target p53 in cancer. Biochemical Pharmacology. v. 80, n. 5, p. 724-30, 2010.

CHEN, J. J.; JIANG, C. Z.; BRITT, A. B. Little or No Repair of Cyclobutyl Pyrimidine Dimers Is Observed in the Organellar Genomes of the Young Arabidopsis Seedling. Plant Physiology. v. 111, n. 1, p. 19-25, 1996.

CICCIA, A.; ELLEDGE, S. J. The DNA Damage Response: Making It Safe to Play with Knives. Molecular Cell. v. 66, n. 7, p. 3485-94, 2010.

CIMPRICH, K. A.; CORTEZ, D. ATR: an essential regulator of genome integrity. Nature Reviews Molecular Cell Biology. v. 9, p. 616-627, 2008. 
CLAYTON, D. A.; DODA, J. N.; FRIEDBERG, E. C. The absence of a pyrimidine dimer repair mechanism in mammalian mitochondria. Proceedings of the National Academy of Sciences of the United States of America. v. 71, n. 7, p. 2777-81, 1974.

DAMAS, J.; CARNEIRO, J.; AMORIM, A.; PEREIRA, F. MitoBreak: the mitochondrial DNA breakpoints database. Nucleic Acids Research. v. 42, p. 1261-1268, 2014.

DE LAAT, W. L.; JASPERS, N. G.; HOEIJMAKERS, J. H. Molecular mechanism of nucleotide excision repair. Genes and Development. v. 13, n. 7, p. 768-85, 1999.

DE SOUZA-PINTO, N. C.; EIDE, L.; HOGUE, B. A.; THYBO, T.; STEVNSNER, T.; SEEBERG, E.; KLUNGLAND, A.; BOHR, V. A. Repair of 8-oxodeoxyguanosine lesions in mitochondrial dna depends on the oxoguanine dna glycosylase (OGG1) gene and 8-oxoguanine accumulates in the mitochondrial dna of OGG1-defective mice. Cancer Research. v. 61, n. 14, p. 5378-81, 2001.

DE SOUZA-PINTO, N. C.; HARRIS, C. C.; BOHR, V. A. p53 functions in the incorporation step in DNA base excision repair in mouse liver mitochondria. Oncogene. v. 23, n. 39, p. 6559-68, 2004.

DE, S. J.; KUMARI, R.; MUDGAL, P.; MODI, S.; GUPTA, K.; FUTAMI, H.; GOTO, N. M.; LINDOR, Y.; FURUICHI, D.; MOHANTY, E.; SENGUPTA, S. RECQL4 is essential for the transport of p53 to mitochondria in normal human cells in the absence of exogenous stress. Journal of Cell Science. n. 125, p. 2509-2522, 2012.

DELEO, A. B.; JAY, G.; APPELLA, E.; DUBOIS, G. C.; LAW, L. W.; OLD, L. J. Detection of a transformation-related antigen in chemically induced sarcomas and other transformed cells of the mouse. Proceedings of the National Academy of Sciences of the United States of America. v. 76, n. 5, p. 2420-4, 1979.

DEMOTT, M. S.; ZIGMAN, S.; BAMBARA, R. A. Replication protein A stimulates long patch DNA base excision repair. The Journal of Biological Chemistry. v. 273, n. 42, p. 27492-27498, 1998.

DIANOV, G.; LINDAHL, T. Reconstitution of the DNA base excision-repair pathway. Current Biology. v. 4, p. 1069-1076, 1994. 
DIANOV, G.; PRICE, A.; LINDAHL, T. Generation of single-nucleotide repair patches following excision of uracil residues from DNA. Molecular and Cellular Biology. v. 12, n. 4, p. 1605-1612, 1992.

DIAS, G. C. Geração de linhagens celulares HEK293 knockdown para as proteínas p53, ATM, mTOR e PGC1a e estudo do papel de p53 na resposta ao estresse oxidativo provocado por azul de metileno. 2013. 66 f. Dissertação (Mestrado em Bioquímica) Instituto de Química, Universidade de São Paulo, São Paulo, 2013.

DINARDO, M.; MUSICCO, C.; FRACASSO, F.; MILELLA, F.; GADALETA, M.; GADALETA, G; CANTATORE, P. Acetylation and level of mitochondrial transcription fator $A$ in several organs of young and old rats. Biochemical and Biophysical Research Communications. v. 301, n. 1, p. 187-191, 2003.

DODSON, M. L.; LLOYD, R. S. Mechanistic comparisons among base excision repair glycosylases. Free Radicals in Biology and Medicine. v. 32, n. 8, p. 678-682, 2002.

EISEN, J. A.; HANAWALT, P. C. A phylogenomic study of DNA repair genes, proteins, and processes. Mutatation Research. v. 435, n. 3, p. 171-213, 1999.

EL-DEIRY, W. S.; KERN, S. E.; PIETENPOL, J. A.; KINZLER, K. W.; VOGELSTEIN, B. Definition of a consensus binding site for p53. Nature Genetics. v. 1, n. 1, p. 45-9, 1992.

ESSMANN, F.; POHLMANN, S.; GILLISSEN, B.; DANIEL, P. T.; SCHULZE-OSTHOFF, K.; JÄNICKE, R. U. Irradiation-induced translocation of p53 to mitochondria in the absence of apoptosis. The Journal of Biological Chemistry. v. 280, n. 44, p. 37169-77, 2005.

FENG, Z.; LEVINE, A. J. The regulation of energy metabolism and the IGF-1/mTOR pathways by the p53 protein. Trends in Cell Biology. n. 20, p. 427-434, 2010.

FISHEL, M.; SEO, Y.; SMITH, M.; KELLEY, M. Imbalancing the DNA Base Excision Repair Pathway in the Mitochondria; Targeting and Overexpressing $\mathrm{N}$ Methylpurine DNA glycosylase in Mitochondria Leads to Enhanced Cell Killing. Cancer Research. v. 63, p. 608-15, 2003.

FRIEDBERG, E. C. DNA damage and repair. Nature. v. 421, p. 436-40, 2003. 
FRIEDBERG, E. C.; WALKER, G. C.; SIEDE, W.; WOOD, R. D.; SCHULTZ, R. A.; ELLENBERGER, T. Introduction to Mutagenesis: DNA Repair and Mutagenesis. Washington: ASM Press, 2006.

FROMME, J. C.; BANERJEE, A.; VERDINE, G. L. DNA glycosylase recognition and catalysis. Current Opinion in Structural Biology. v. 14, n. 1, p. 43-49, 2004.

GALLUZZI, L. Mitochondrial control of cellular life, stress, and death. Circulation Research. v. 32, n. 18, p. 5596-5608, 2012.

GOTTLIEB, R. A. Mitochondria: execution central. FEBS Letters. v. 25, n. 482, p. 6-12, 2000.

GREENAWALT, J. W. The isolation of outer and inner mitochondrial membranes. Methods Enzymology. v. 31, p. 310-23, 1974.

GROTE, M.; WOLF, E.; WILL, C. L.; LEMM, I.; AGAFONOV, D. E.; SCHOMBURG, A.; FISCHLE, W.; URLAUB, H.; LÜHRMANN, R. Molecular architecture of the human Prp19/CDC5L complex. Molecular and Cellular Biology. v. 30, n. 9, p. 2105-19, 2010.

GUIMARAES, D. P.; HAINAUT, P. TP53: a key gene in human cancer. Biochimie. v. 84, n. 1, p. 83-93, 2002.

HAINAUT, P.; VAHAKANGAS, K. p53 as a sensor of carcinogenic exposures: mechanisms of p53 protein induction and lessons from p53 gene mutations. Pathologie Biologie (Paris). v. 45, n. 10, p. 833-44, 1997.

HAKANSSON, P.; HOFER, A.; THELANDER, L. Regulation of mammalian ribonucleotide reduction and dNTP pools after DNA damage and in resting cells. The Journal of Biological Chemistry. v. 12, n. 281, p. 7834-7841, 2006.

HANAWALT, P. C. Subpathways of nucleotide excision repair and their regulation. Oncogene. v. 21, n. 58, p. 8949-56, 2002.

HANAWALT, P. C.; FORD, J. M.; LLOYD, D. R. Functional characterization of global genomic DNA repair and its implications for cancer. Mutation Research. v. 544, n. 2-3, p. 107-14, 2003. 
HARMAN, D. Free radical theory of aging. Mutation Research. v. 275, n. 3-6, p. 257266, 1992.

HARMAN, D. The biologic clock: the mitochondria? Journal of the American Geriatric Society. v. 20, n. 4, p. 145-147, 1972.

HARMAN, D. Aging: a theory based on free radical and radiation chemistry. Journal Gerontolology. v. 11, n. 3, p.298-300, 1956.

HARPER, J. W.; ELLEDGE, S. J. The DNA Damage Response: Ten Years After. Molecular Cell. v. 28, p. 739-745, 2007.

HASAN, S.; HOTTIGER, M. O. Histone acetyl transferases: a role in DNA repair and DNA replication. Journal of Molecular Medicine. v. 80, p. 463-74, 2002.

HASHIGUCHI, K.; STUART, J. A.; DE SOUZA-PINTO, N. C.; BOHR, V. A. The C-terminal alpha $O$ helix of human Ogg1 is essential for 8-oxoguanine DNA glycosylase activity: the mitochondrial beta-Ogg1 lacks this domain and does not have glycosylase activity. Nucleic Acids Research. v. 32, n. 18, p. 5596-5608, 2004.

HAYASHI, Y.; YOSHIDA, M.; YAMATO, M.; IDE, T.; WU, Z.; OCHI-SHINDOU, M.; KANKI, T.; KANG, D.; SUNAGAWA, K.; TSUTSUI, H.; NAKANISHI, H. Reverse of age-dependent memory impairment and mitochondrial DNA damage in microglia by an overexpression of human mitochondrial transcription factor $A$ in mice. Journal of Neuroscience. v. 28, n. 34, p. 8624-34, 2008.

HEINRICHS, S.; DEPPERT, W. Apoptosis or growth arrest: modulation of the cellular response to p53 by proliferative signals. Oncogene. v. 22, n. 4, p. 555-71, 2003.

HEYNE, K.; SCHMITT, K.; MUELLER, D.; ARMBRUESTER, V.; MESTRES, P.; ROEMER, K. Resistance of mitochondrial p53 to dominant inhibition. Molecular Cancer. 2008.

HOEIJMAKERS, J. H. J. DNA damage, aging, and cancer. The New England Journal of Medicine. v. 361, p. 1475-1485, 2009. 
HOLLEY, A. K.; DHAR, S. K.; ST CLAIR, D. K. Manganese superoxide dismutase versus p53: the mitochondrial center. Annals of The New York Academy of Science. n. 1201, p. 72-78, 2010.

IKEHATA, H. R.; OKUYAMA, E.; OGAWA, S.; NAKAMURA, A.; USAMI, T.; MORI, K.; TANAKA, S.; AIBA, E. T. O. Influences of p53 deficiency on the apoptotic response, DNA damage removal and mutagenesis in UVB-exposed mouse skin. Mutagenesis. n. 25, p. 397-405, 2010.

IKEUCHI, M.; MATSUSAKA, H., KANG, D.; MATSUSHIMA, S.; IDE, T.; KUBOTA, T.; FUJIWARA, T.; HAMASAKI, N.; TAKESHITA, A.; SUNAGAWA, K.; TSUTUI, $H$. Overexpression of mitochondrial transcription factor $A$ ameliorates mitochondrial deficiencies and cardiac failure after myocardial infarction. Circulation. n. 112, p. 68390, 2005.

JACKSON, S. P.; BARTEK, J. The DNA-damage response in human biology and disease. Nature. v. 461, p. 1071-1078, 2009.

KAINA, B.; CHRISTMANN, M.; NAUMANN, S.; ROOS, W. P. MGMT: key node in the battle against genotoxicity, carcinogenicity and apoptosis induced by alkylating agents. DNA Repair (Amst). v. 6, n. 8, p. 1079-99, 2007.

KANG, D.; HAMASAKI, N. Mitochondrial transcription factor A in the maintenance of mitochondrial DNA: overview of its multiple roles. Annals of The New York Academy of Science. v. 1024, p. 101-8, 2005.

KASIVISWANATHAN, R.; LONGLEY, M. J.; YOUNG, M. J.; COPELAND, W. C. Purification and functional characterization of human mitochondrial DNA polymerase gamma harboring disease mutations. Methods. v. 51, n. 4, p. 379-84, 2010.

KIM, G. J.; FISKUM, G. M.; MORGAN, W. F. A role for mitochondrial dysfunction in perpetuating radiation-induced genomic instability. Cancer Research. n. 66, p. 1037783, 2006.

KLUNGLAND, A.; LINDAHL, T. Second pathway for completion of human DNA base excision-repair: reconstitution with purified proteins and requirement for DNase IV (FEN1). The EMBO Journal. v. 16, n. 11, p. 3341-3348, 1997. 
KONDO, N. DNA damage induced by alkylating agents and repair pathways. Journal of Nucleic Acids. v. 2010, p. 543-531, 2010.

KORSHUNOV, S. S.; SKULACHEV, V. P.; STARKOV, A. A. High protonic potential actuates a mechanism of production of reactive oxygen species in mitochondria. FEBS Letters. $v$. 416, n. 1, p. 15-18, 1997.

KOWALTOWSKI, A. J.; VERCESI, A. E. Reactive oxygen generation by mitochondria: Mitochondria in Pathogenesis. New York: Academic Press Publishers, 2001.

KRISHNAN, K. J.; GREAVES, L. C.; REEVE, A. K.; TURNBULL, D. The ageing mitochondrial genome. Nucleic Acids Research. v. 35, n. 22, p. 7399-7405, 2007.

LAGOUGE, M.; LARSSON, N. G. The role of mitochondrial DNA mutations and free radicals in disease and ageing. Journal of Internal Medicine. v. 273, p. 529-43, 2013.

LAKSHMIPATHY, U.; CAMPBELL, C. Mitochondrial DNA ligase III function is independent of Xrcc1. Nucleic Acids Research. v. 28, n. 20, p. 3880-3886, 2000.

LANE, D. P.; CRAWFORD, L. V. T antigen is bound to a host protein in SV40-transformed cells. Nature. v. 278, n. 5701, p. 261-3, 1979.

LEBEDEVA, M. A.; SHADEL, G. S. Cell cycle- and ribonucleotide reductase-driven changes in mtDNA copy number influence mtDNA Inheritance without compromising mitochondrial gene expression. Cell Cycle (Georgetown, Texas). v. 29, n. 6, p. 20482057, 2007.

LEDOUX, S. P.; WILSON, G. L.; BEECHAM, E. J.; STEVNSNER, T.; WASSERMANN, K.; BOHR, V. A. Repair of mitochondrial DNA after various types of DNA damage in Chinese hamster ovary cells. Carcinogenesis. v. 13, n. 11, p. 1967-73, 1992.

LEMON, J. A.; ROLLO, C. D.; BOREHAM, D. R. Elevated DNA damage in a mouse model of oxidative stress: impacts of ionizing radiation and a protective dietary supplement. Mutagenesis. n. 23, p. 473-82, 2008. 
LEVIN, D. S.; MCKENNA, A. E.; MOTYCKA, T. A.; MATSUMOTO, Y.; TOMKINSON, A. E. Interaction between PCNA and DNA ligase $I$ is critical for joining of Okazaki fragments and long-patch base-excision repair. Current Biology. v. 10, n. 15, p. 919-922, 2000.

LI, B.; CAREY, M.; WORKMAN, J. The Role of Chromatin during Transcription. Cell. n. 128, p. 707-19, 2007.

LIGHTOWLERS, R. N.; CHINNERY, P. F.; TURNBULL, D. M.; HOWELL, N. Mammalian mitochondrial genetics: heredity, heteroplasmy and disease. Trends Genetics. v. 13, n. 11, p. 450-5, 1997.

LINDAHL, T. Suppression of spontaneous mutagenesis in human cells by DNA base excision-repair. Mutation Research. v. 462, n. 2-3, p. 129-35, 2000.

LINDAHL, T.; BARNES, D. E. Repair of endogenous DNA damage. Cold Spring Harbor Symposia on Quantitative Biology. 2000.

LINNANE, A. W.; MARZUKI, S.; OZAWA, T.; TANAKA, M. Mitochondrial DNA mutations as an important contributor to ageing and degenerative diseases. The Lancet Oncology. v. 1, n. 8639, p. 642-645, 1989.

LINZER, D. I.; LEVINE, A. J. Characterization of a 54K dalton cellular SV40 tumor antigen present in SV40-transformed cells and uninfected embryonal carcinoma cells. Cell. v. 17, n. 1, p. 43-52, 1979.

LIU, P.; QIAN, L.; SUNG, J. S.; DE SOUZA-PINTO, N. C.; ZHENG, L., BOGENHAGEN, D. F.; BOHR, V. A.; WILSON III, D. M.; SHEN, B.; DEMPLE, B. Removal of oxidative DNA damage via FEN1-dependent long-patch base excision repair in human cell mitochondria. Molecular and Cellular Biology. v. 28, n. 16, p. 4975-4987, 2008.

LONGLEY, M. J.; PRASAD, R.; SRIVASTAVA, D. K.; WILSON, S. H.; COPELAND, W. C. Identification of 5'-deoxyribose phosphate lyase activity in human DNA polymerase gamma and its role in mitochondrial base excision repair in vitro. Proceedings of the National Academy of Sciences of the United States of America. v. 95, n. 21, p. 1224412248, 1998.

LORD, C. J.; ASHWORTH, A. The DNA damage response and cancer therapy. Nature. 2012. 
LU, B.; LEE, J.; NIE, X.; LI, M.; MOROZOV, Y.; VENKATESH, S.; BOGENHAGEN, D. F.; TEMIAKOV, D.; SUZUKI, C. Phospholylation of human TFAM in mitochondria impairs DNA binding and promotes degradation by the AAA+ Lon Protease. Molecular Cell. v. 49, p. 1-12, 2013.

LU, L.; LEJTENYI, D.; OSMOND, D. G. Regulation of cell survival during B lymphopoiesis: suppressed apoptosis of pro-B cells in p53-deficient mouse bone marrow. European Journal of Immunology. v. 29, n. 8, p. 2484-90, 1999.

MANDAL, S. M.; HEGDE, M. L.; CHATTERJEE, A.; HEGDE, P. M.; SZCZESNY, B.; BANERJEE, D.; BOLDOGH, I.; GAO, R.; FALKENBERG, M.; GUSTAFSSON, C. M.; SARKAR, P. S.; HAZRA, T. K. Role of human DNA glycosylase Nei-like 2 (NEIL2) and single strand break repair protein polynucleotide kinase $3^{\prime}$-phosphatase in maintenance of mitochondrial genome. The Journal of Biological Chemistry. v. 287, n. 4, p. 2819-2829, 2012.

MARCHENKO, N. D. A.; ZAIKA, E.; MOLL, U. Death signal-induced localization of p53 protein to mitochondria. A potential role in apoptotic signaling. The Journal of Biological Chemistry. n. 275, p. 16202-16212, 2000.

MATTIAZZI, M.; VIJAYVERGIYA, C.; GAJEWSKI, C. D.; DEVIVO, D. C.; LENAZ, G.; WIEDMANN, M.; MANFREDI, G. The mtDNA T8993G (NARP) mutation results in an impairment of oxidative phosphorylation that can be improved by antioxidants. Human Molecular Genetics. v. 13, n. 3, p. 869-879, 2004.

MAYNARD, S.; DE SOUZA-PINTO, N. C.; SCHEIBYE-KNUDSEN, M.; BOHR, V. A. Mitochondrial base excision repair assays. Methods. v. 51, n. 4, p. 416-25, 2010.

MENCK, C. F.; MUNFORD, V. DNA repair diseases: What do they tell us about cancer and aging? Genetics and Molecular Biology. v. 37, p. 220-233, 2014.

MIHARA, M.; ERSTER, S.; ZAIKA, A.; PETRENKO, O.; CHITTENDEN, T.; PANCOSKA, P.; MOLL, U. M. p53 has a direct apoptogenic role at the mitochondria. Molecular Cell. v. 11, n. 3, p. 577-90, 2003.

MOLL, U. M.; ZAIKA, A. Nuclear and mitochondrial apoptotic pathways of $\mathrm{p53}$. The FEBS Letter. v. 493, n. 2-3, p. 65-9, 2001. 
MORI, M. P. Novo papel da proteína XPC na regulação dos complexos da cadeia de transporte de elétrons e desequilíbrio redox. 2015. $173 \mathrm{f}$. Tese (Doutorado em Bioquímica) - Instituto de Química, Universidade de São Paulo, São Paulo, 2015.

MORIMOTO, N.; MIYAZAKI, K.; KURATA, T.; IKEDA, Y.; MATSUURA, T.; KANG, D.; IDE, T.; $A B E, K$. Effect of mitochondrial transcription factor $A$ overexpression on motor neurons in amyotrophic lateral sclerosis model mice. Journal of Neuroscience Research. v. 90, p. 1200-08, 2012.

MUFTUOGLU, M.; MORI, M. P.; DE SOUZA-PINTO, N. C. Formation and repair of oxidative damage in the mitochondrial DNA. Mitochondrion. v. 3, n. 3, p. 162-172, 2014.

MULLER-HOCKER, J. Cytochrome-c-oxidase deficient cardiomyocytes in the human heart - an age-related phenomenon. A histochemical ultracytochemical study. American Journal of Pathology. v. 134, p. 1167-1173, 1989.

NAIR, U.; BARTSCH, H.; NAIR, J. Lipid peroxidation-induced DNA damage in cancerprone inflammatory diseases: A review of published adduct types and levels in humans. Free Radical Biology and Medicine. v. 450, n. 3, p. 197-204, 2007.

NAKANO, K.; BALINT, E.; ASHCROFT, M.; VOUSDEN, K. H. A ribonucleotide reductase gene is a transcriptional target of p53 and p73. Oncogene. n. 19, p. 4283-4289, 2000.

NILSEN, H.; OTTERLEI, M.; HAUG, T.; SOLUM, K.; NAGELHUS, T. A.; SKORPEN, F.; KROKAN, H. E. Nuclear and mitochondrial uracil-DNA glycosylases are generated by alternative splicing and transcription from different positions in the UNG gene. Nucleic Acids Research. v. 25, n. 4, p. 750-755, 1997.

NISHIOKA, K.; OHTSUBO, T.; ODA, H.; FUJIWARA, T.; KANG, D.; SUGIMACHI, K.; NAKABEPPU, Y. Expression and differential intracellular localization of two major forms of human 8-oxoguanine DNA glycosylase encoded by alternatively spliced OGG1 mRNAs. Molecular Biology of The Cell. v. 10, p. 1637-1652, 1999.

OFFER, H.; ZURER, G.; BANFALVI, M.; REHA'K, A.; FALCOVITZ, M.; MILYAVSKY, N.; GOLDFINGER, E. V. p53 modulates base excision repair activity in a cell cycle-specific manner after genotoxic stress. Cancer Research. v. 8, n. 61, p. 88-96, 2001b. 
OFFER, H.; MILYAVSKY, M.; EREZ, N.; MATAS, D.; ZURER, I.; HARRIS, C.C.; ROTTER, V. Structural and functional involvement of p53 in BER in vitro and in vivo. Oncogene. v. 20, n. 5, p. 581-9, 2001 a.

OFFER, H.; WOLKOWICZ, R.; MATAS, D.; BLUMENSTEIN, S.; LIVNEH, Z.; ROTTER, V. Direct involvement of $\mathrm{p} 53$ in the base excision repair pathway of the DNA repair machinery. The FEBS Letters. v. 450, n. 3, p. 197-204, 1999.

PEI, X. H.; NAKANISHI, Y.; TAKAYAMA, K.; BAI, F.; HARA, N. Benzo[a]pyrene activates the human p53 gene through induction of nuclear factor kappaB activity. The Journal of Biological Chemistry. v. 274, n. 49, p. 35240-6, 1999.

PETROS, J. A.; BAUMANN, A. K.; RUIZ-PESINI, E.; AMIN, M. B.; SUN, C. Q.; HALL, J.; LIM, S.; ISSA, M. M.; FLANDERS, W. D.; HOSSEINI, S. H.; MARSHALL, F. F.; WALLACE, D. C. mtDNA mutations increase tumorigenicity in prostate cancer. Proceedings of the National Academy of Sciences of the United States of America. v. 102, n. 3, p. 719724, 2005.

POLO, S. E.; JACKSON, S. P. Dynamics of DNA damage response proteins at DNA breaks: a focus on protein modifications. Genes and Development. v. 25, p. 409-433, 2011.

PUEBLA-OSORIO, N.; LACEY, D. B.; ALT, F. W.; ZHU, C. Early embryonic lethality due to targeted inactivation of DNA ligase III. Molecular and Cellular Biology. v. 26, n. 10, p. 3935-3941, 2006.

RAO, K. S. Mechanisms of Disease: DNA repair defects and neurological disease. Nature Clinical Practice Neurology. v. 3, n. 3, p. 162-172, 2007.

ROMAGNA, C.; MORI, M. P.; DE SOUZA-PINTO, N. C. Lesões oxidativas em DNA: detecção, formação, reparo e envolvimento em carcinogênese. In. Tratado de Oncologia Médica. São Paulo: Editora Atheneu, 2014.

RUCHKO, M.; GORODNA, O.; LEDOUX, S. P.; ALEXEVEV, M. F.; AL-MEHDI, A. B.; GILLESPIE, M. N. Mitochondrial DNA damage triggers mitochondrial dysfunction and apoptosis in oxidant-challenged lung endothelial cells. American Journal of Physiology-Lung Cellular and Molecular Physiology. v. 288, n. 3, p. L530-5, 2005. 
SANCAR, G. B. Enzymatic photoreactivation: 50 years and counting. Mutation Research. v. 451, n. 1-2, p. 25-37, 2000.

SANTOS, V. T. Estudo dos mecanismos moleculares do reparo de quebra de duplas fitas no DNA mitocondrial. 2015. 107 f. Tese (Doutorado em Bioquímica) - Instituto de Química, Universidade de São Paulo, São Paulo, 2015.

SCARPULLA, R. C.; VEGA, R. B.; KELLY, D. P. Transcriptional integration of mitochondrial biogenesis. Trends in Endocrinology and Metabolism. v. 271, n. 44, p. 27536-43, 2012.

SCHON, E. A.; DIMAURO, S.; HIRANO, M. Human mitochondrial DNA: roles of inherited and somatic mutations. Nature Review Genetics. v. 13, n. 12, p. 881, 2012.

SEIDEL-ROGOL, B. L.; SHADEL, G. S. Modulation of mitochondrial transcription in response to mtDNA depletion and repletion in HeLa cells. Nucleic Acids Research. n. 30, p. 1929-1934, 2002.

SEO, Y. R.; FISHEL, S.; AMUNDSON, M. R.; KELLEY, E.; SMITH, E. M. Implication of p53 in base excision DNA repair: in vivo evidence. Oncogene. n. 21, p. 731-737, 2002.

SHADEL, G. S. Expression and maintenance of mitochondrial DNA: new insights into human disease pathology. The American Journal of Pathology. n. 172, p. 1445-1456, 2008.

SINGHAL, R. K.; PRASAD, R.; WILSON, S. H. DNA polymerase beta conducts the gap filling step in uracil-initiated base excision repair in a bovine testis nuclear extract. The Journal of Biological Chemistry. v. 270, n. 2, p. 949-957, 1995.

SIONOV, R. V.; HAUPT, Y. The cellular response to p53: the decision between life and death. Oncogene. v. 18, n. 45, p. 6145-57, 1999.

SLUPPHAUG, G.; KAVLI, B.; KROKAN, H.E. The interacting pathways for prevention and repair of oxidative DNA damage. Mutation Reserch. v. 531, n. 1-2, p. 231-51, 2003.

STIERUM, R. H.; DIANOV, G. L.; BOHR, V. A. Single-nucleotide patch base excision repair of uracil in DNA by mitochondrial protein extracts. Nucleic Acids Research. v. 27, n. 18, p. 3712-3719, 1999. 
SU, T. T. Cellular responses to DNA damage: one signal, multiple choices. Annual Review of Genetics. v. 40, p. 187-208, 2006.

SUGO, N.; ARATANI, Y.; NAGASHIMA, Y.; KUBOTA, Y.; KOYAMA, H. Neonatal lethality with abnormal neurogenesis in mice deficient in DNA polymerase beta. The EMBO Journal. v. 19, n. 6, p. 1397-1404, 2000.

TANAKA, H.; ARAKAWA, H.; YAMAGUCHI, T.; SHIRAISHI, K.; FUKUDA, S.; MATSUI, K.; TAKEI, Y.; NAKAMURA, Y. A ribonucleotide reductase gene involved in a p53dependent cell-cycle checkpoint for DNA damage. Nature. v. 45, n. 404, p. 42-49, 2000.

TAYLOR, R. W.; TURNBULL, D. M. Mitochondrial DNA mutations in human disease. Nature Reviews Genetics. v. 6, n. 5, p. 389-402, 2005.

TEBBS, R. S.; FLANNERY, M. L.; MENESES, J. J.; HARTMANN, A.; TUCKER, J. D.; THOMPSON, L. H.; CLEAVER, J. E.; PEDERSEN, R. A. Requirement for the Xrcc1 DNA base excision repair gene during early mouse development. Developmental Biology. v. 208, n. 2, p. 513-529, 1999.

TELL, G.; DAMANTE, G.; CALDWELL, D.; KELLEY, M. R. The intracellular localization of APE1/Ref-1: more than a passive phenomenon? Antioxidants and Redox Signaling. v. 7, n. 3-4, p. 367-384, 2005.

THYAGARAJAN, B.; PADUA, R. A.; CAMPBELL, C. Mammalian mitochondria possess homologous DNA recombination activity. Journal of Biological Chemistry. v. 271, n. 44, p. 27536-43, 1996.

TOMKINSON, A. E.; BONK, R. T.; KIM, J.; BARTFELD, N.; LINN, S. Mammalian mitochondrial endonuclease activities specific for ultraviolet-irradiated DNA. Nucleic Acids Research. v. 18, n. 4, p. 929-35, 1990.

TONOLLI, P. N. O papel do fator de transcrição mitocondrial A (TFAM) na proteção do DNA mitocondrial contra lesões oxidadas. 2013. 70 f. Dissertação (Mestrado em Bioquímica) - Instituto de Química, Universidade de São Paulo, São Paulo, 2013.

TROUNCE, I.; NEILL, S.; WALLACE, D. C. Cytoplasmic transfer of the mtDNA nt 8993 $T \rightarrow G$ (ATP6) point mutation associated with Leigh syndrome into mtDNA less cells 
demonstrate cosegregation with a decrease in state III respiration and ADP/O ratio. Proceedings of the National Academy of Sciences of the United States of America. v. 91, p. 8334-8338, 1994.

VAN DER SCHANS, G. P. Gamma-ray induced double-strand breaks in DNA resulting from randomly-inflicted single-strand breaks: temporal local denaturation, a new radiation phenomenon? International Journal of Radiation Biology and Related Studies in Physics, Chemistry and Medicine. v. 33, p. 105-120, 1978.

VASEVA, A. V.; MARCHENKO, K.; JI, S. E.; TSIRKA, S.; HOLZMANN, U.; MOLL, M. p53 opens the mitochondrial permeability transition pore to trigger necrosis. Cell. n. 149, p. 1536-1548, 2012.

VERCESI, A. E. Mitochondrial energy metabolism and redox state in dyslipidemias. lubmb Life. v. 59, p. 263-268, 2007.

WALLACE, D. C. Mitochondrial DNA mutations in disease and aging. Environmental and Molecular Mutagenesis. v. 51, n. 5, p. 440-50, 2010.

WANG, W.; EL-DEIRY, W. S. Bioluminescent molecular imaging of endogenous and exogenous p53-mediated transcription in vitro and in vivo using an HCT116 human colon carcinoma xenograft model. Cancer Biology and Therapy. v. 2, n. 2, p. 196-202, 2003.

WARMERDAM, D. O.; KANAAR, R. Dealing with DNA damage: Relationships between checkpoint and repair pathways. Mutation Research - Reviews in Mutation Research. 2010.

WEINBERG, R. A. p53 e Apoptose: Guardião e Executor. In. A Biologia do Câncer. Porto Alegre: Artmed, 2008.

WEISSMAN, L.; DE SOUZA-PINTO, N. C.; STEVNSNER, T.; BOHR, V. A. DNA repair, mitochondria, and neurodegeneration. Neuroscience. v. 145, n. 4, p. 1318-1329, 2007.

WIEBAUER, K.; JIRICNY, J. Mismatch-specific thymine DNA glycosylase and DNA polymerase beta mediate the correction of G.T mispairs in nuclear extracts from human cells. Proceedings of the National Academy of Sciences of the United States of America. v. 87, n. 15, p. 5842-5845, 1990. 
WONG, T. S.; RAJAGOPALAN, S.; TOWNSLEY, F. M.; FREUND, S. M.; PETROVICH, M.; LOAKES, D.; FERSHT, A. R. Physical and functional interactions between human mitochondrial single-stranded DNA-binding protein and tumour suppressor p53. Nucleic Acids Research. v. 37, n. 2, p. 568-81, 2009.

WOODS, D. B.; VOUSDEN, K. H. Regulation of p53 function. Experimental Cell Research. v. 264, n. 1, p. 56-66, 2001.

XANTHOUDAKIS, S.; SMEYNE, R. J.; WALLACE, J. D.; CURRAN, T. The redox/DNA repair protein, Ref-1, is essential for early embryonic development in mice. Proceedings of the National Academy of Sciences of the United States of America. v. 93, n. 17, p. 8919-23, 1996.

XU, S.; ZHONG, M.; ZHANG, L.; WANG, Y.; ZHOU, Z.; HAO, Y.; ZHANG, W.; YANG, X.; WEI, A.; PEI, L.; YU, Z. Overexpression of TFAM protects mitochondria against $b$ amiloid-induced oxidative damage in SH-SY5Ycells. The FEBS Journal. v. 276, p. 380009, 2009.

YANG, J. L. et al. Mitochondrial DNA damage and repair in neurodegenerative disorders. DNA Repair. v. 7, p. 1110-1120, 2008.

YANG, W. Surviving the sun: Repair and bypass of DNA UV lesions. Protein Science. 2011.

YOSHIDA, Y.; IZUMI, H.; ISE, T.; URAMOTO, H.; TORIGOE, T.; ISHIGUCHI, H.; MURAKAMI, T.; TANABE, M.; NAKAYAMA, Y.; ITOH, H.; KASAI, H.; KOHNO, K. Human mitochondrial transcription factor $A$ binds preferentially to oxidatively damaged DNA. Biochemical and Biophysical Research Communications. v. 295, p. 945-51, 2002.

ZHAO, Y. L.; CHAISWING, J. M.; VELEZ, I.; BATINIC-HABERLE, N. H.; COLBURN, T. D.; OBERLEY, E.; ST CLAIR, D. K. p53 translocation to mitochondria precedes its nuclear translocation and targets mitochondrial oxidative defense protein-manganese superoxide dismutase. Cancer Research. v. 65, n. 65, p. 3745-3750, 2005.

ZHARKOV, D. O. Base excision DNA repair. Cellular and Molecular Life Sciences. v. 65, n. 10, p. 1544-1565, 2008. 
ZHOU, J.; AHN, S. H.; WILSON, E. C. A role for p53 in base excision repair. The EMBO Journal. v. 98, n. 20, p. 914-923, 2001. 
